\title{
A Novel Catalyst System for Suzuki-Miyaura Coupling of Challenging DNA-Linked Aryl Chlorides
}

\author{
Yun Ding, ${ }^{*}$ Jennifer L. DeLorey, ${ }^{\dagger}$ Matthew A. Clark $^{\S}$ \\ GlaxoSmithKline, Platform Technology \& Science, ELT-Boston, 830 Winter Street, Waltham, MA 02451, \\ USA.
}

\section{Supporting Information}

\section{Analytical Methods}

On-DNA reactions were analyzed by LCMS. Samples (ca. 100 pmol) were injected onto a

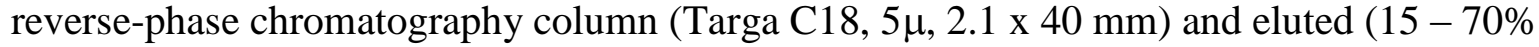
solvent B over 7 minutes, $0.36 \mathrm{~mL} / \mathrm{min}$ flow rate, 10-60\% solvent B over 3 minutes, 0.55 $\mathrm{mL} / \mathrm{min}$ flow rate, or $10-60 \%$ solvent $\mathrm{B}$ over 7 minutes, $0.55 \mathrm{~mL} / \mathrm{min}$ flow rate ; or column (hypersil Gold, 30x2.1 mm) and eluted $(10-60 \%$ solvent B over 3 minutes, $0.5 \mathrm{~mL} / \mathrm{min}$ flow rate; Solvent A: $0.75 \%$ hexafluoroisopropanol (HFIP) / 0.38\% triethylammonium acetate $/ 10 \mu \mathrm{M}$ EDTA in deionized water; Solvent B: 0.75\% HFIP/0.38\% TEAA/10 $\mu$ M EDTA in 90/10 methanol/water) with monitoring at $260 \mathrm{~nm}$. Effluent was analyzed on a ThermoFinnigan Advantage electrospray mass spectrometer in negative ion mode. Chromatographic purification

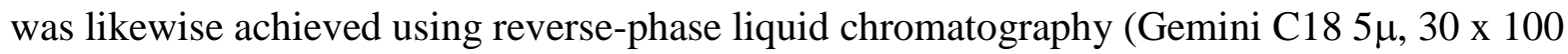
mm; Solvent A: pH 7.5 $50 \mathrm{mM}$ triethylammonium acetate; Solvent B: $1 \%$ water in acetonitrile).

Yields were calculated by examination of the UV and TIC traces of the LCMS chromatograms.

Materials. All the reagents were purchased through vendors. They were dissolved in an appropriate solvent before use. DNA headpiece (HP) $\left(5^{\prime}-\right.$ /5Phos/GAGTCA/iSp9/iUniAmM/iSp9/TGACTCCC-3') was obtained from Biosearch Technologies, Novato, CA.

“Headpiece (HP).” Sequence: 5'-/5Phos/GAGTCA/iSp9/iUniAmM/iSp9/TGACTCCC-3' 


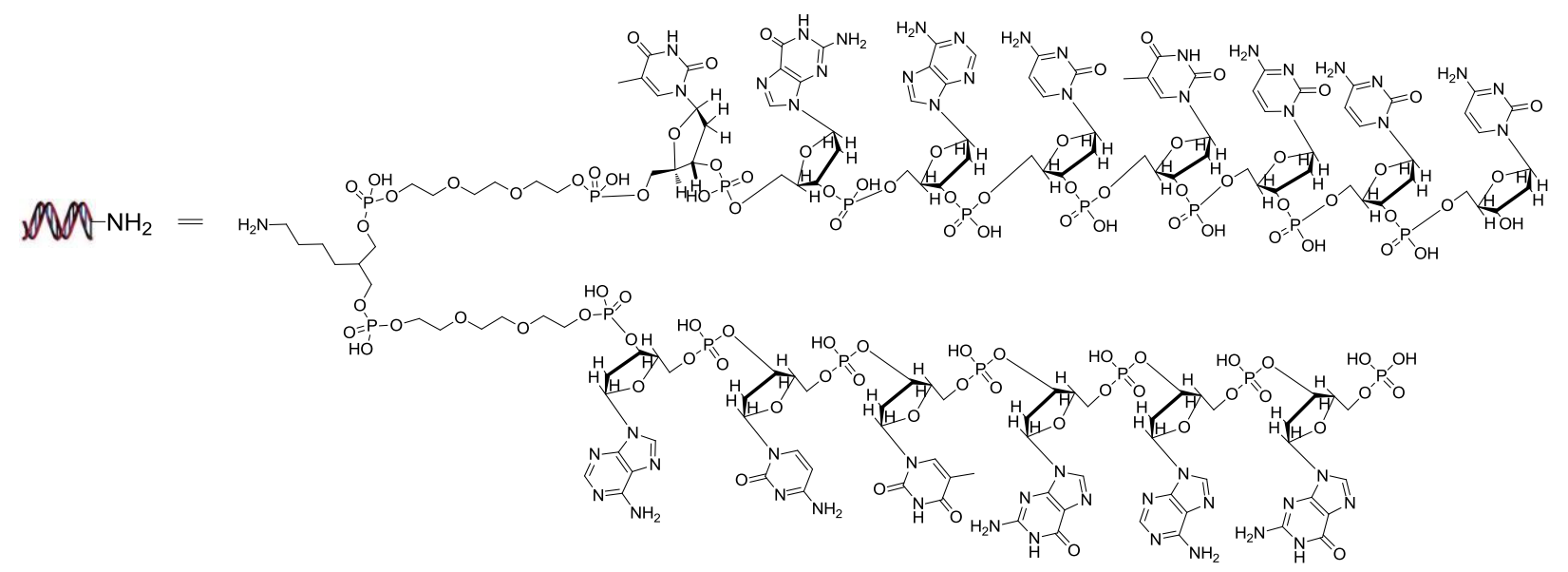

Figure 1. Sequence and structure of the "headpiece." MW $=4937 \mathrm{D}$

\section{$\underline{\text { Preparation of HP-3 }}$}

A solution of $\mathbf{H P}$ in pH9.4 borate buffer $(500 \mathrm{mM})(1 \mu \mathrm{mol}, 1 \mathrm{~mL})$ was added at cold 40 equivalents of 4,6-dichloro-2-(methylsulfonyl)pyrimidine ( $200 \mu \mathrm{L}, 200 \mathrm{mM}$ in DMF). After being kept at cold for 2.5 hours, another 40 equivalents of pyrimidine derivative $(200 \mu \mathrm{L}, 200$ $\mathrm{mM}$ in DMF) was added. The reaction was allowed to proceed at cold for another $2 \mathrm{~h}$, followed by treating with $10 \%$ piperidine $(140 \mu \mathrm{L})$ at room temperature for $1.5 \mathrm{~h}$. The reaction was precipitated by adding $10 \% 5 \mathrm{~N} \mathrm{NaCl}$ water solution and 2.5 times volume of absolute $\mathrm{EtOH}$.

General procedure for the coupling of HP-3 with boronates using $\mathrm{Pd}\left(\mathrm{PPh}_{3}\right)_{4}=$

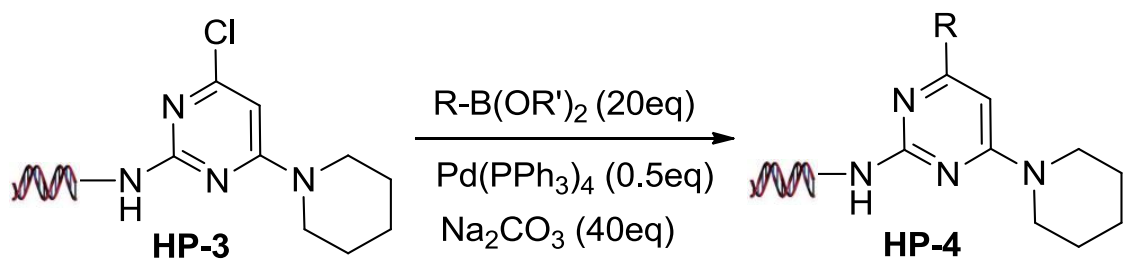

A solution of HP-3 in water $(20 \mathrm{nmol}, 15 \mu \mathrm{L})$ was added 20 equivalents of boronate $(0.5 \mu \mathrm{L}$, $800 \mathrm{mM}$ in DMA) and 40 equivalents of $\mathrm{Na}_{2} \mathrm{CO}_{3}(0.5 \mu \mathrm{L}, 1.6 \mathrm{M}$ in water), followed by 0.25 equivalent of degassed $\mathrm{Pd}\left(\mathrm{PPh}_{3}\right)_{4}\left(1.4 \mu \mathrm{L}, 3.5 \mathrm{mM}\right.$ in $\left.\mathrm{CH}_{3} \mathrm{CN}\right)$. The reaction was allowed to proceed at $80{ }^{\circ} \mathrm{C}$ for 16 hours. 

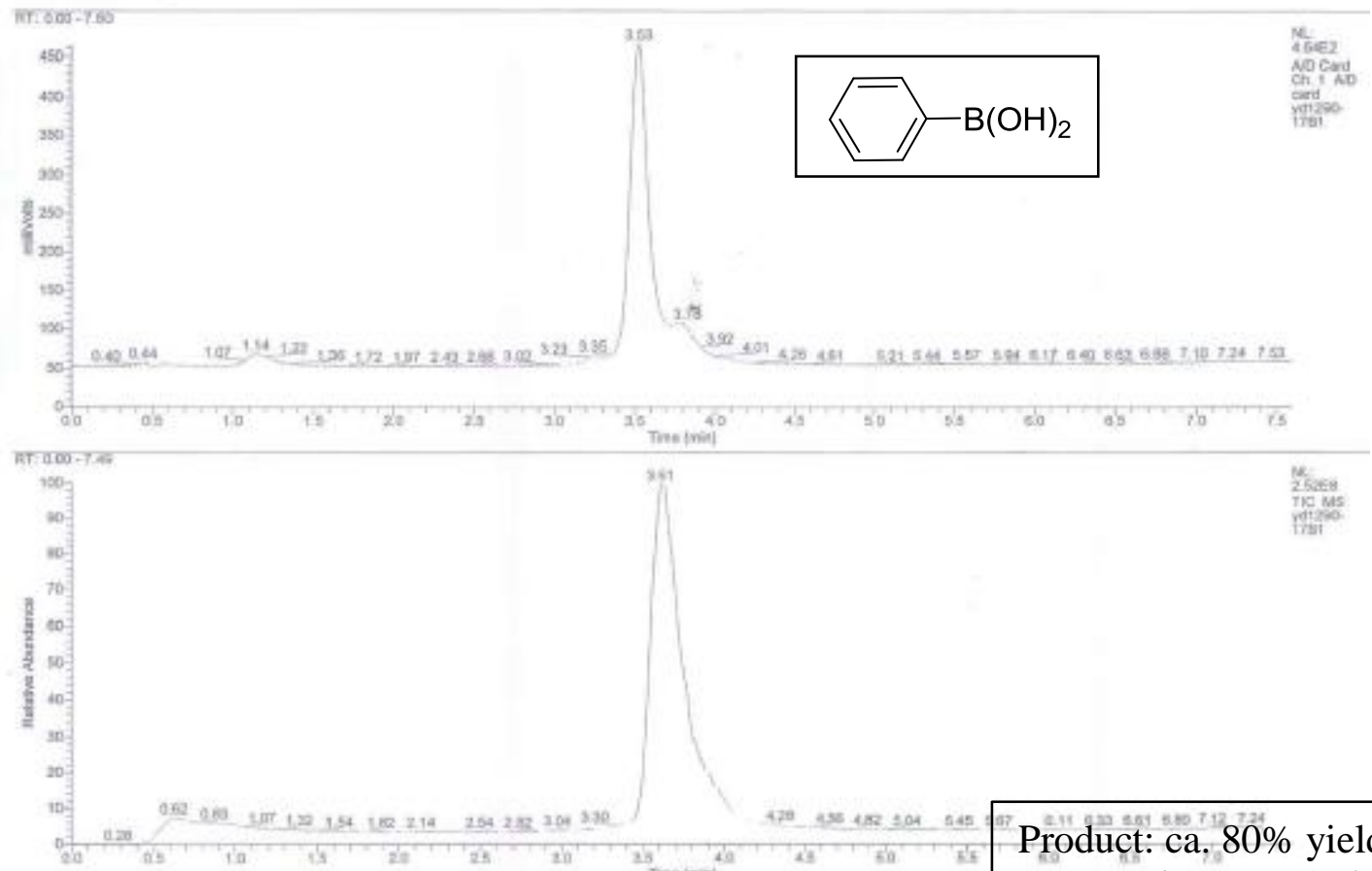

ats

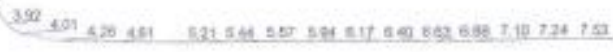

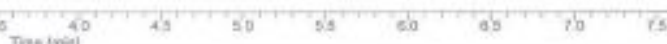

290-17BT \#15-126 RI: $353-3,82$ AV: 12 NLE 3,30E7

Ti-c ESI Full ms [ 400.00-2000.00]

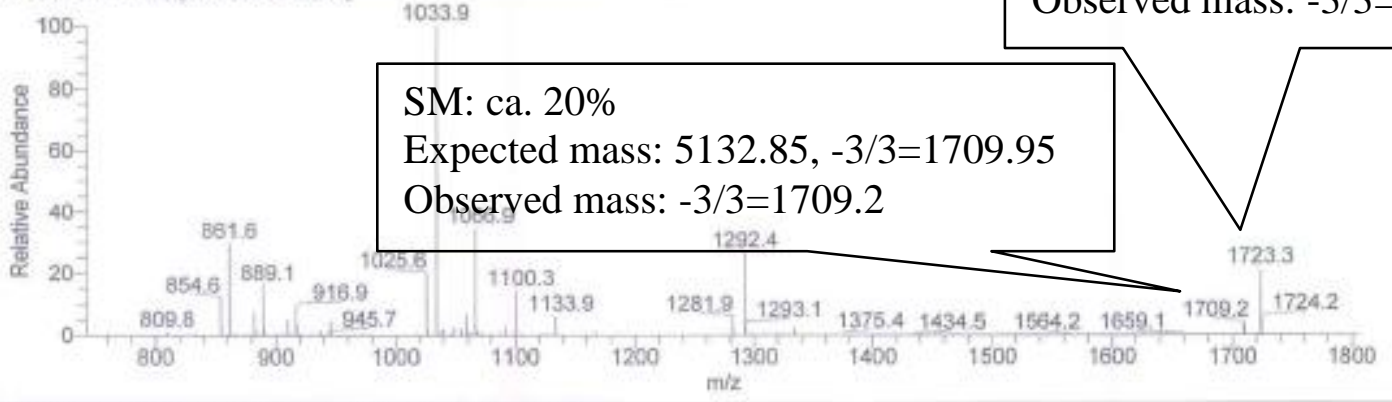

10339

Product: ca, $80 \%$ yield

Expected mass: $5174.50,-3 / 3=1723.83$

Observed mass: $-3 / 3=1723.30$

yd1290-1781 \#122-134 RT: $3.72-4.05$ AV: 13 NE: 8.08E6

1: - c ESt Full ms [ 400.00-2000.00]

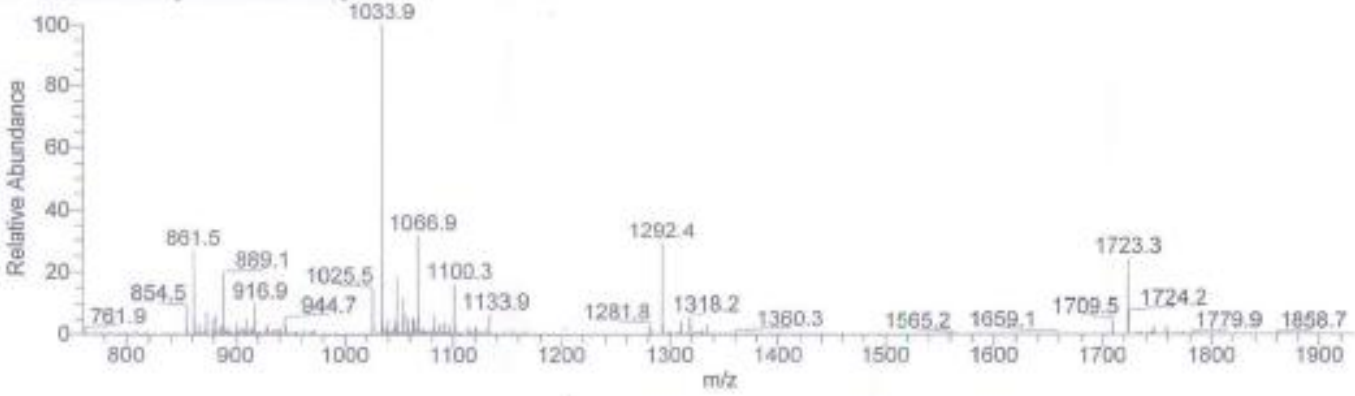




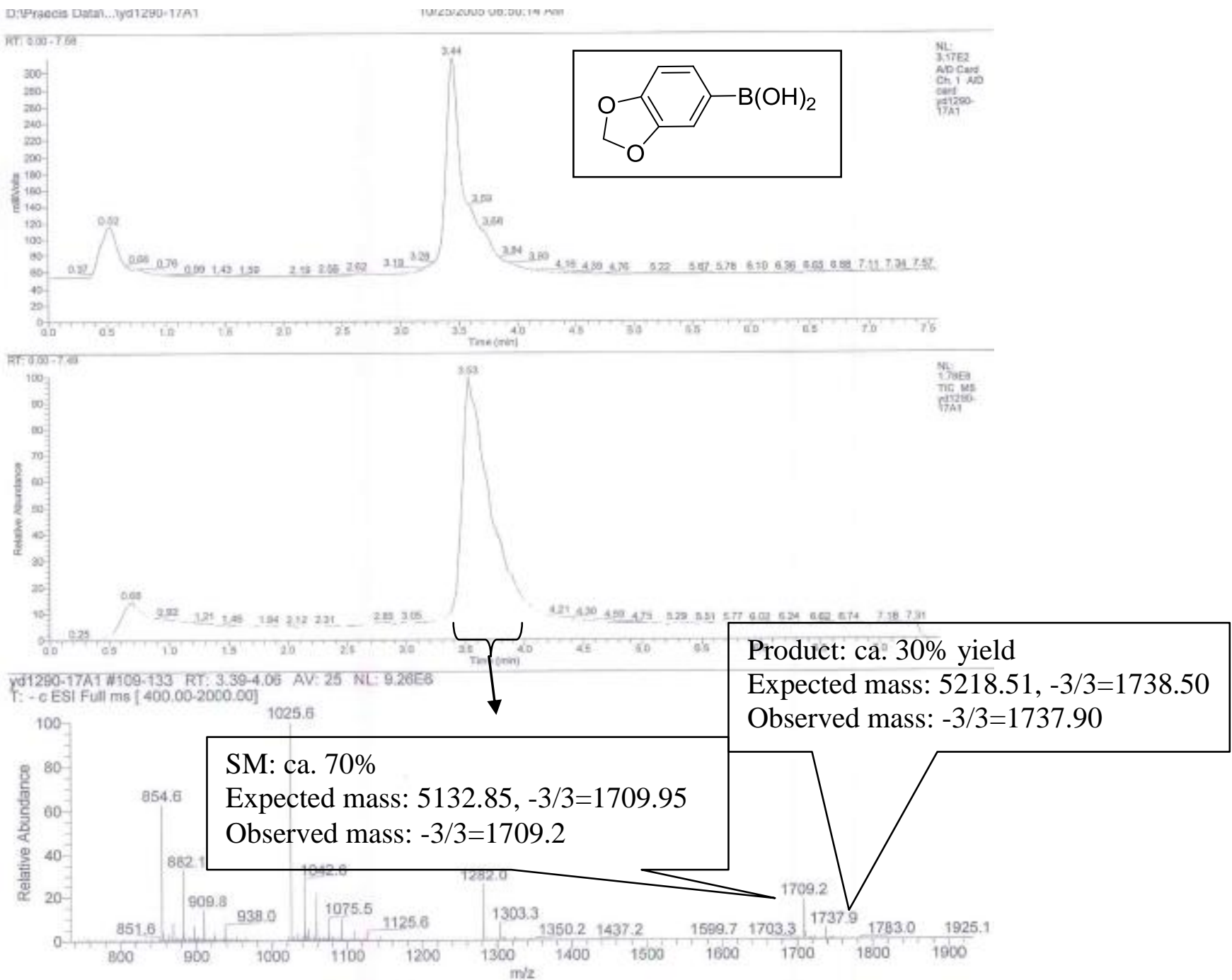


DNFraects Datal, yor280-1707

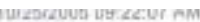
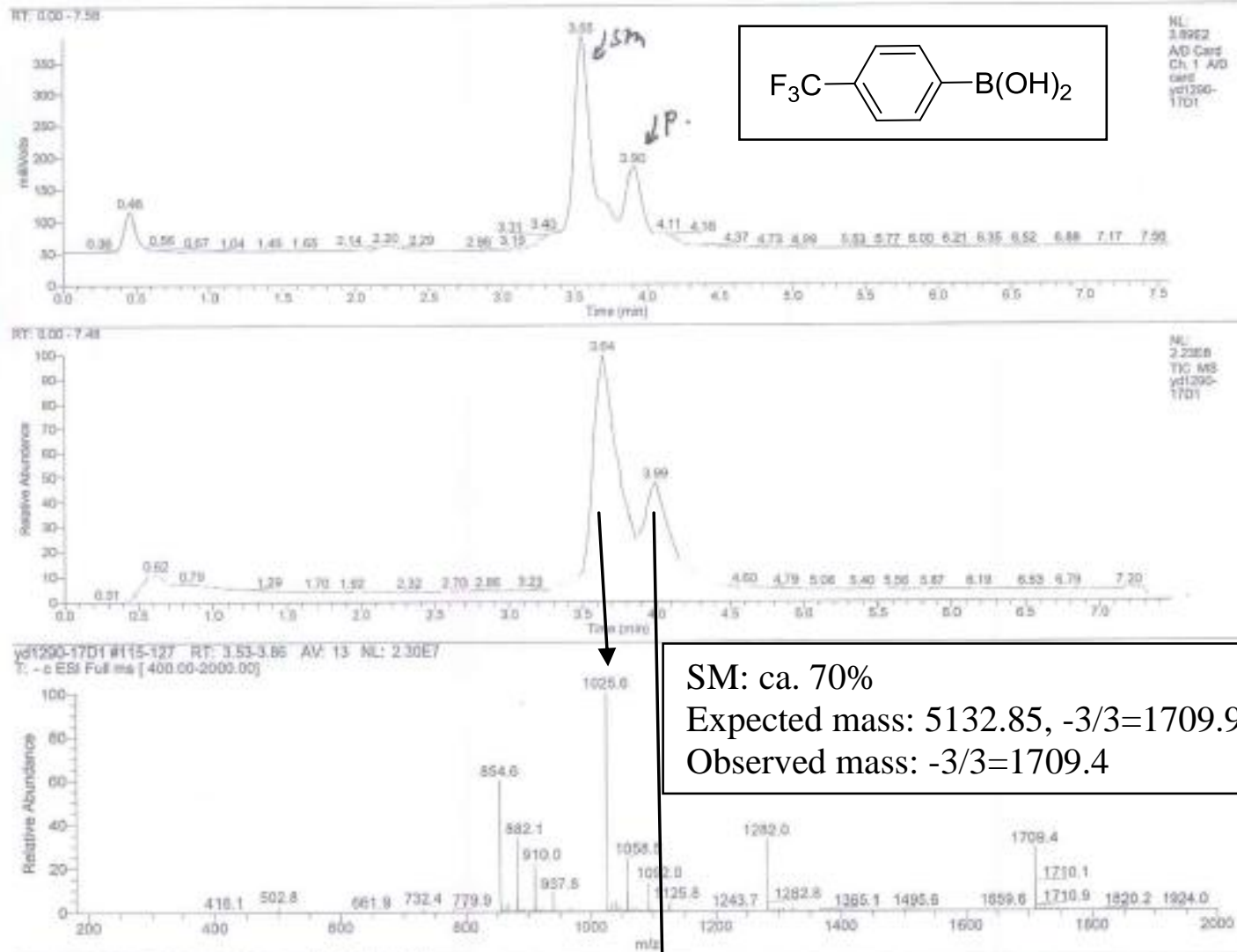

SM: ca. $70 \%$

Expected mass: $5132.85,-3 / 3=1709.95$

Observed mass: $-3 / 3=1709.4$

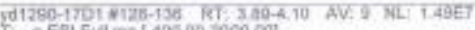

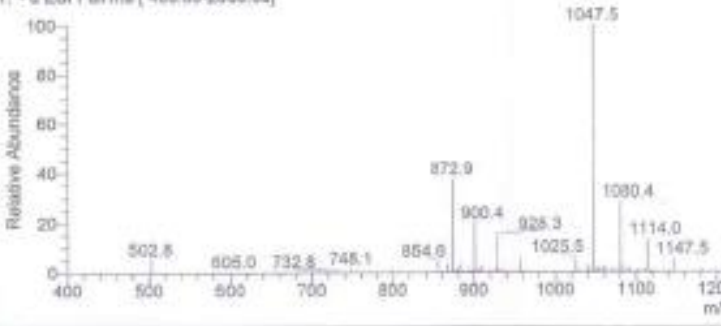

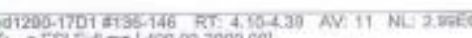

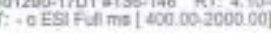

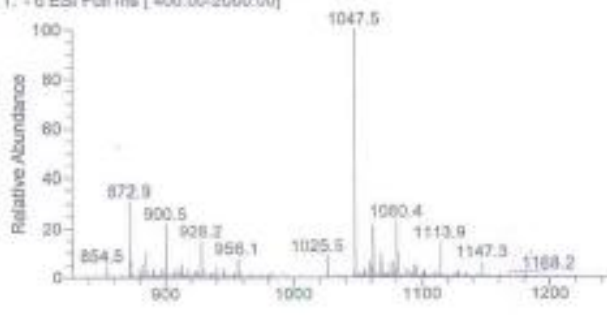

isaso

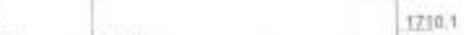

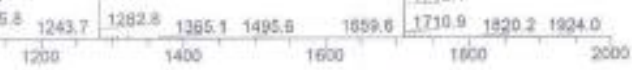

Product: ca. $25 \%$ yield

Expected mass: $5242.49,-3 / 3=1746.50$

Observed mass: $-3 / 3=1745.90$

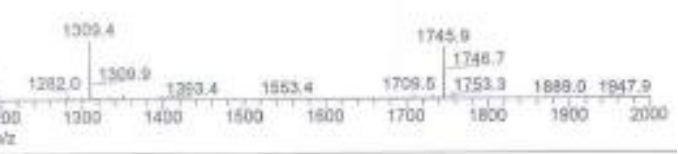

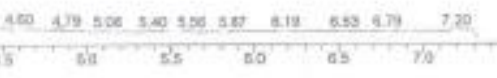


General procedure for the coupling of HP-3 with boronates using POPd, POPd1 and POPd2 (Table 1).

A solution of HP-3 in water $(20 \mathrm{nmol}, 15 \mu \mathrm{L})$ was added 20 equivalents of boronate $(0.5 \mu \mathrm{L}$, $800 \mathrm{mM}$ in DMA) and 40 equivalents of $\mathrm{Na}_{2} \mathrm{CO}_{3}(0.5 \mu \mathrm{L}, 1.6 \mathrm{M}$ in water $)$, followed by 0.5 equivalent of Palladium catalyst (POPd, POPd1, or POPd2) $\left(2 \mu \mathrm{L}, 5 \mathrm{mM}\right.$ in $\left.\mathrm{CH}_{3} \mathrm{CN}\right)$. The reaction was allowed to proceed at $80{ }^{\circ} \mathrm{C}$ for 16 hours. 


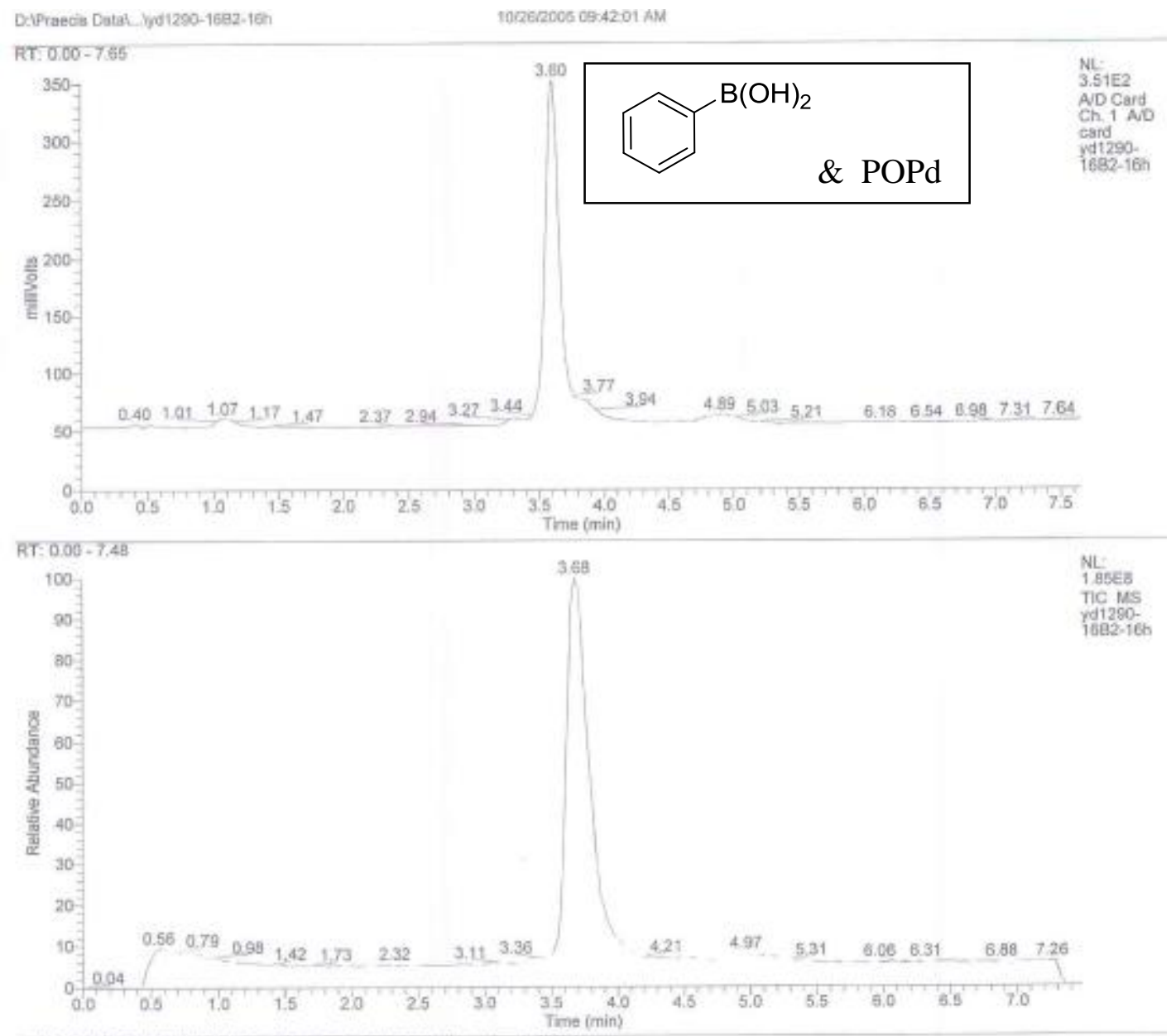

yd1290-16.82-16h \#115-132 RT: 3.54 .4 .01 AV: 18 NL: 1.52E T: - c ESI Full ms [ $400.00-2000,00]$

SM: ca. $30 \%$

Expected mass: $5132.85,-4 / 4=1282.21$

Observed mass: $-4 / 4=1281.81$

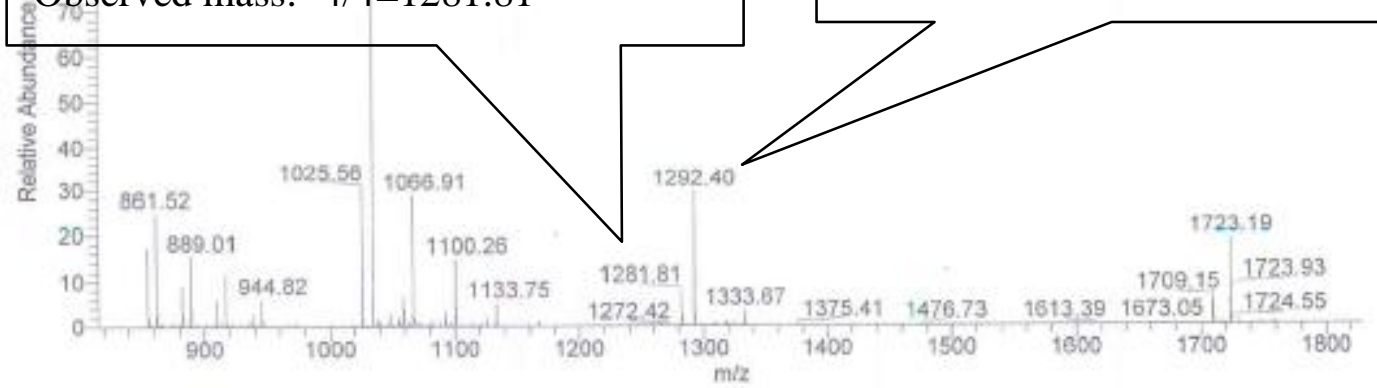




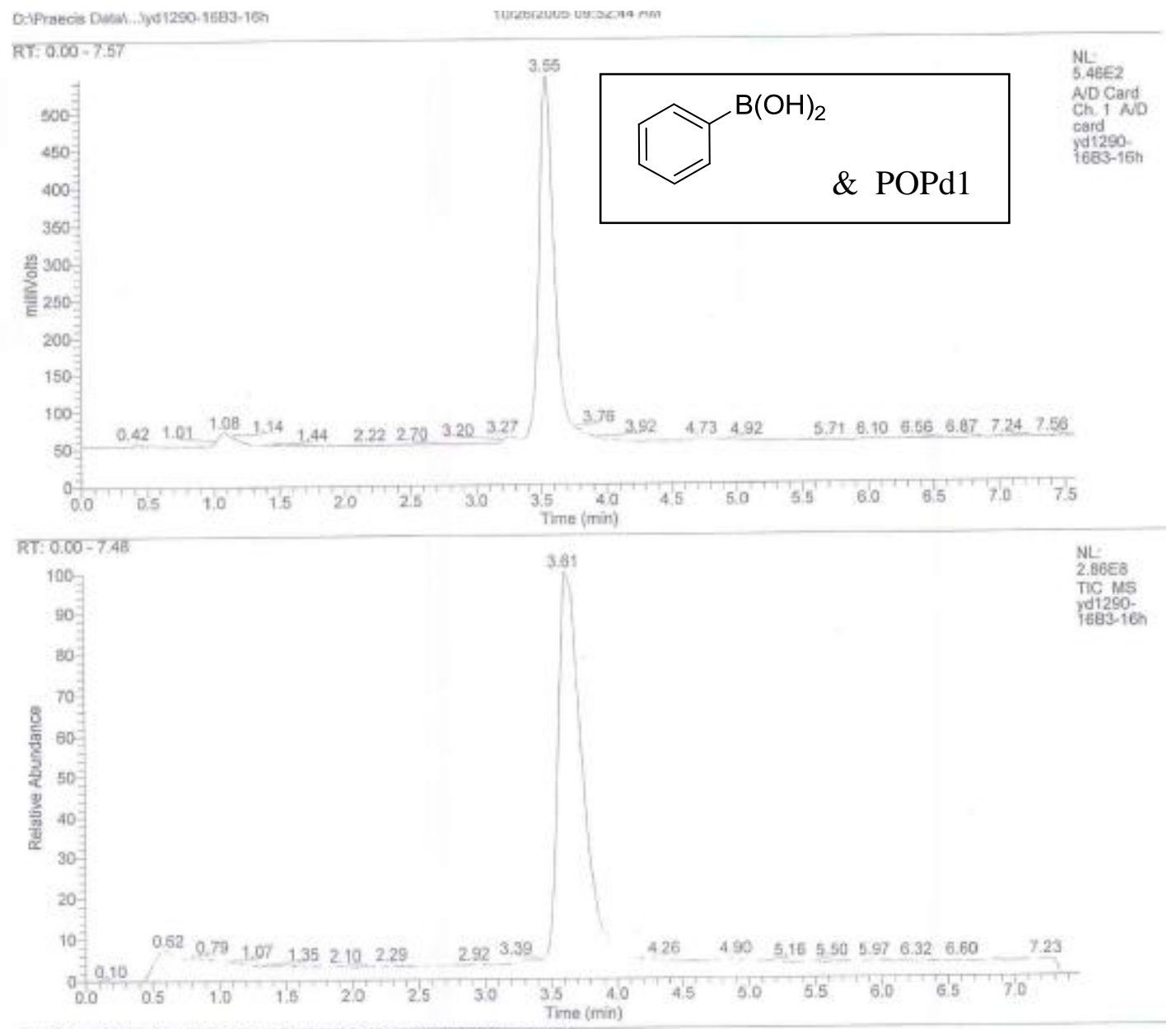

Wd1290-1683-16h \#113-131 RI: $3.48-3.97$ AV: 19 NL: 1.51E? T: - c ESI Full ms [ 400.00-2000.00]

SM: ca. $60 \%$

Expected mass: $5132.85,-4 / 4=1282.21$

Observed mass: $-4 / 4=1281.91$

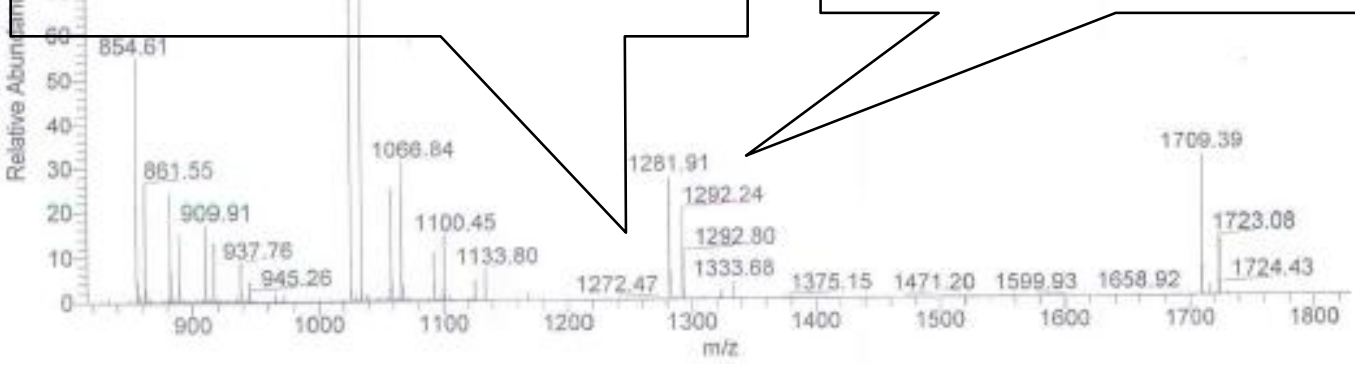




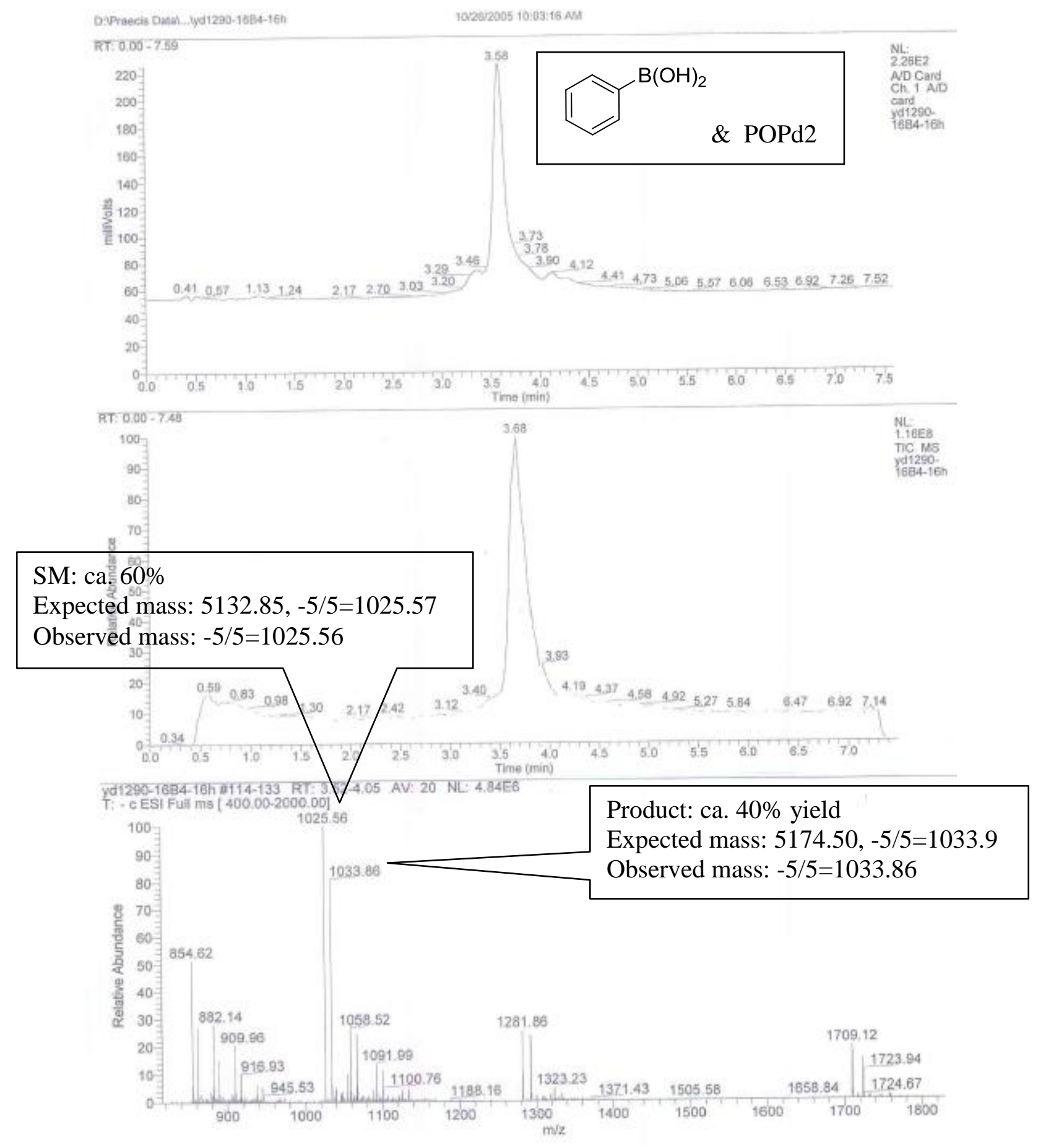




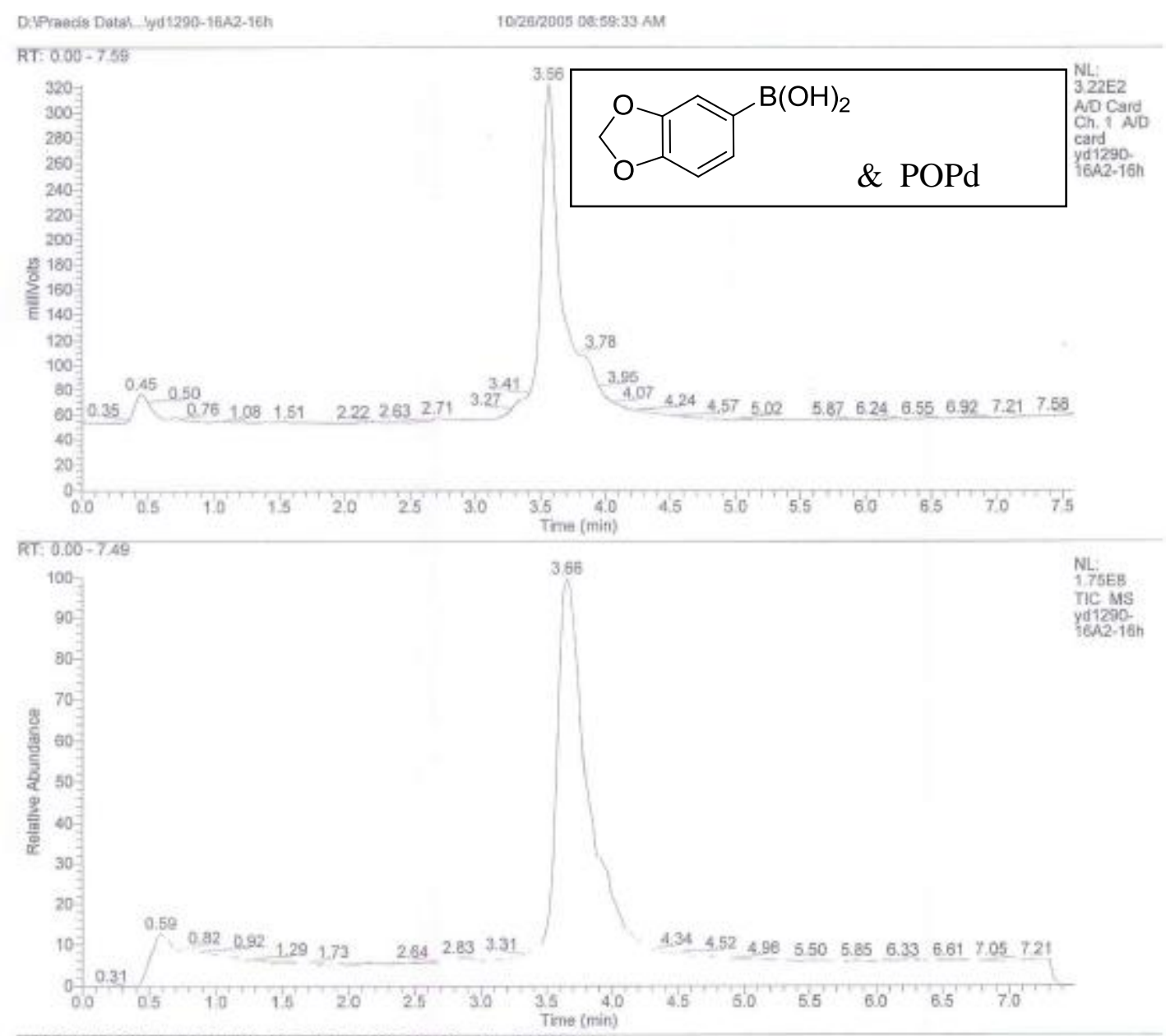

yd1290-16.2.-16h \#113-138 RT: 3.49-4.19 AV: 26 NL: 8.25E T: - c ESI Full ms [ $400.00-2000.00]$

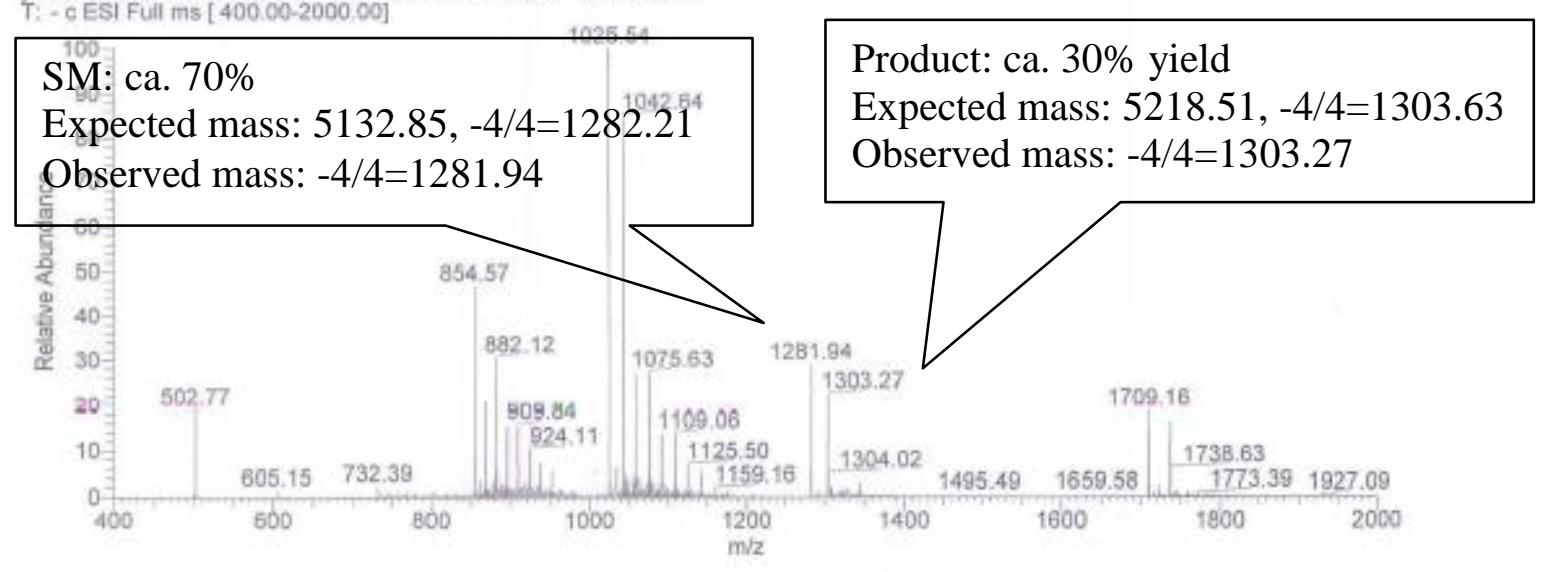




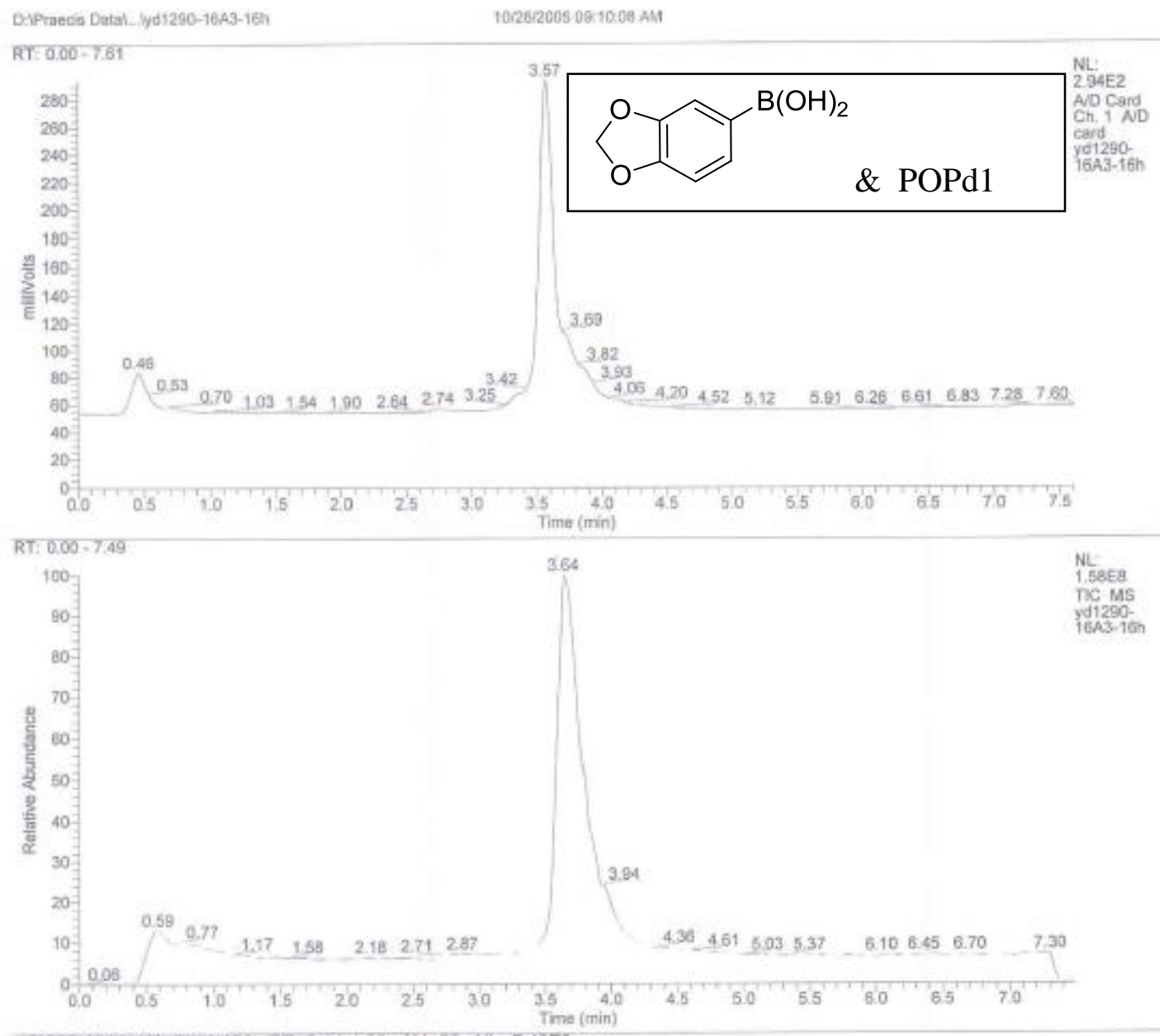

yd1290-16A3-16h\#111-138 RT: $3.44-4.20$ AV: 28 NL: 7.42E'

T: - c ESI Full ms [ $400.00-2000.00]$

1025.53

SM: ca. $85 \%$

Expected mass: $5132.85,-4 / 4=1282.21$

Observed mass: $-4 / 4=1281.93$

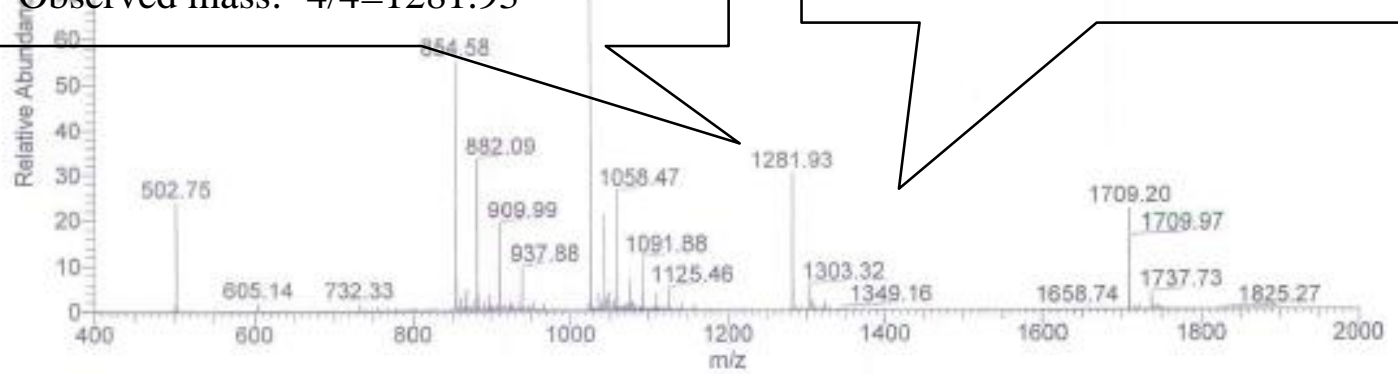

Product: ca. $15 \%$ yield

Expected mass: $5218.51,-4 / 4=1303.63$

Observed mass: $-4 / 4=1303.32$ 


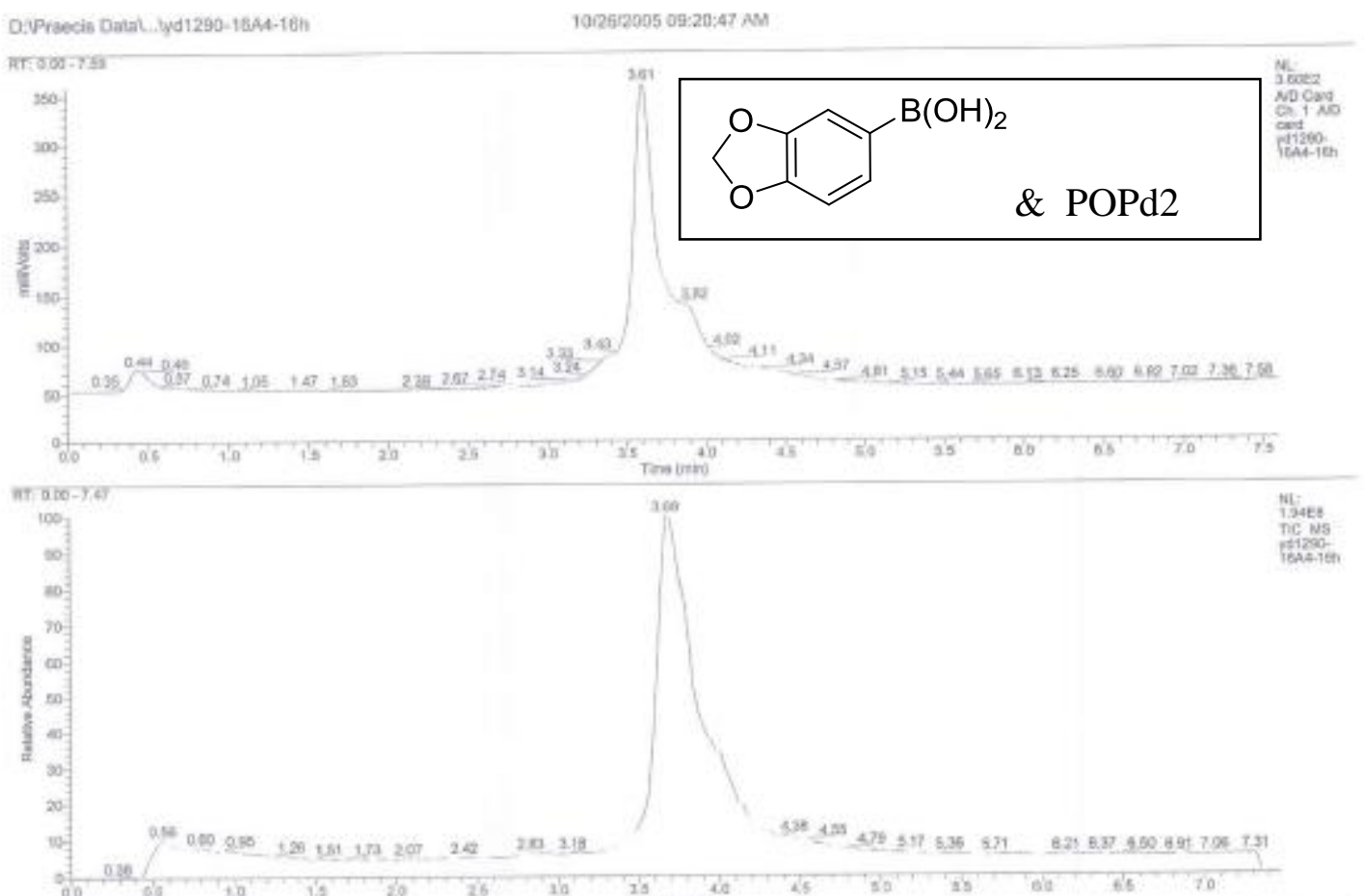

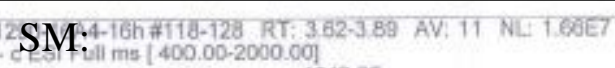

Expected mass: $5132.85,-4 / 4=1282.21$

Observed mass: $-4 / 4=1281.83$

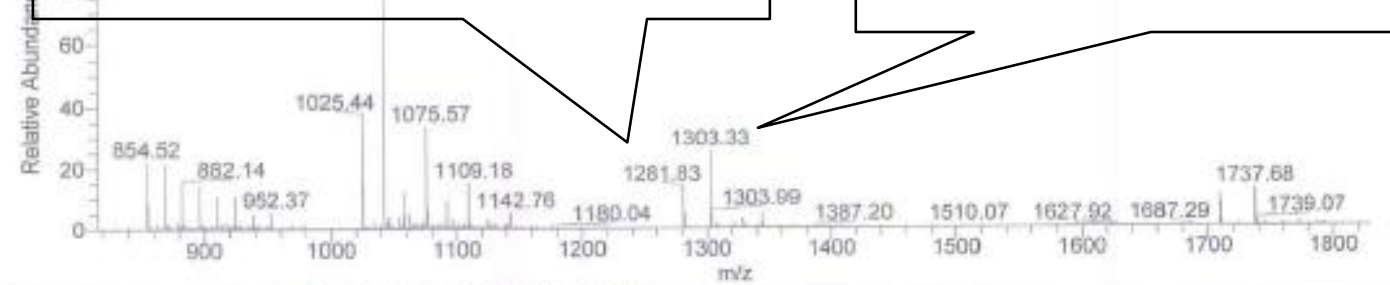

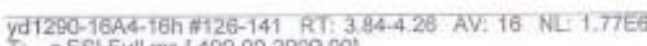
T:-cESI Full ms [ $400.00-2000.00$ t

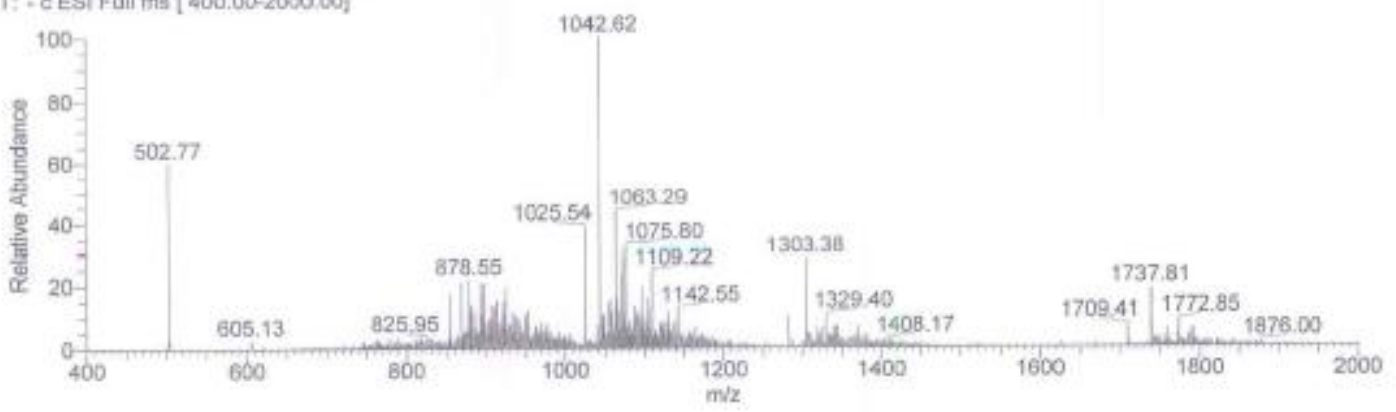


General procedure for the coupling of HP-3 with boronates in Table 2 using POPd .

A solution of HP-3 in water $(20 \mathrm{nmol}, 15 \mu \mathrm{L})$ was added 40 equivalents of boronate $(1 \mu \mathrm{L}, 800$ $\mathrm{mM}$ in DMA) and 80 equivalents of $\mathrm{Cs}_{2} \mathrm{CO}_{3}(1 \mu \mathrm{L}, 1.6 \mathrm{M}$ in water), followed by 1 equivalent of POPd $\left(1 \mu \mathrm{L}, 10 \mathrm{mM}\right.$ in $\left.\mathrm{CH}_{3} \mathrm{CN}\right)$. The reaction was allowed to proceed at $80^{\circ} \mathrm{C}$ for 3.5 hours, followed by adding another portion of the reagents, 40 equivalents of boronate, 80 equivalents of $\mathrm{Cs}_{2} \mathrm{CO}_{3}$ and 1 equivalent of POPd and heating at $80^{\circ} \mathrm{C}$ for 12 hours. 
Table 2, entry 1: LCMS @ 3 h 25 min, after first addition

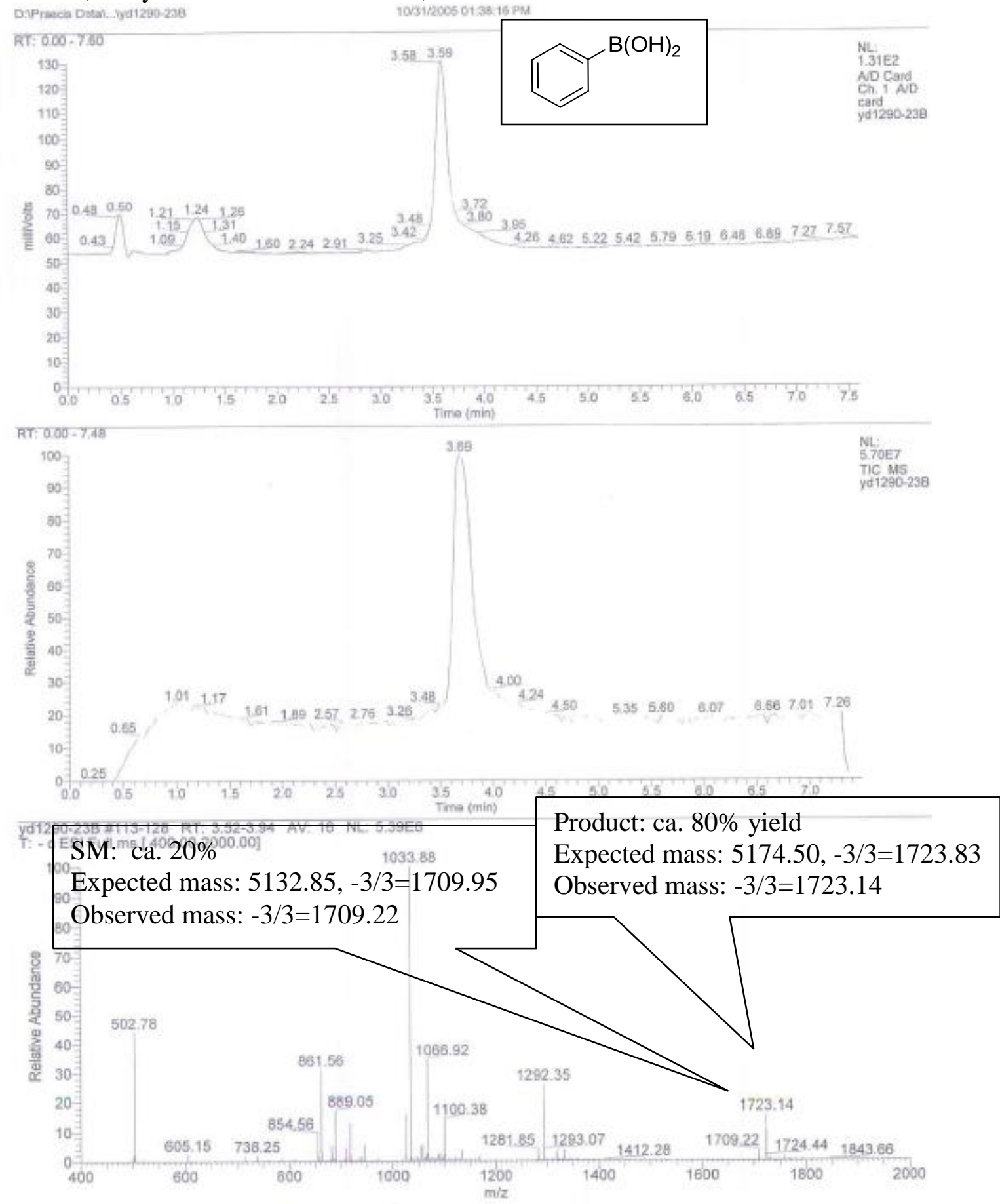


Table 2, entry 1: LCMS @ 12 h after second addition
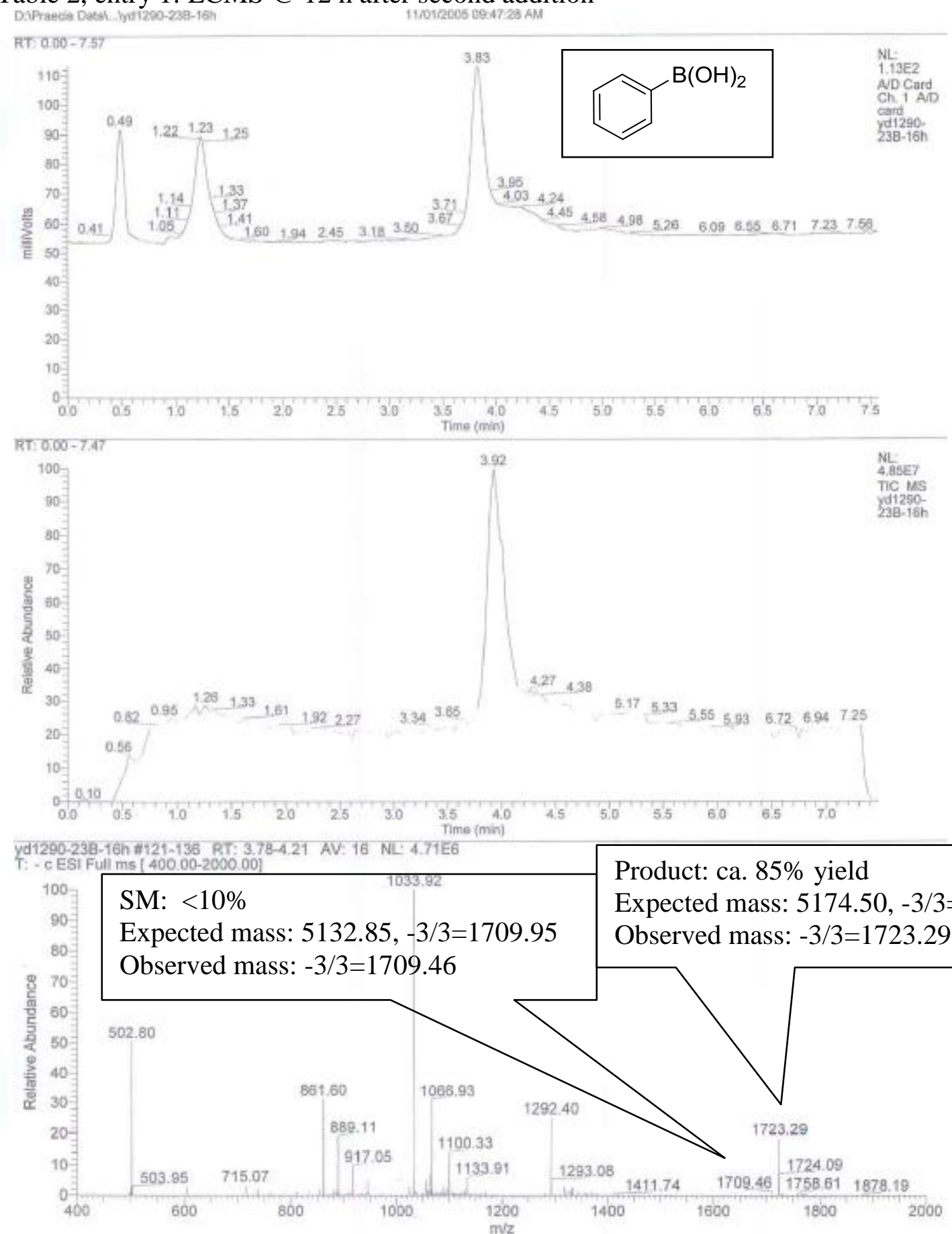
Table 2, entry 2: LCMS @ 3 h 30 min

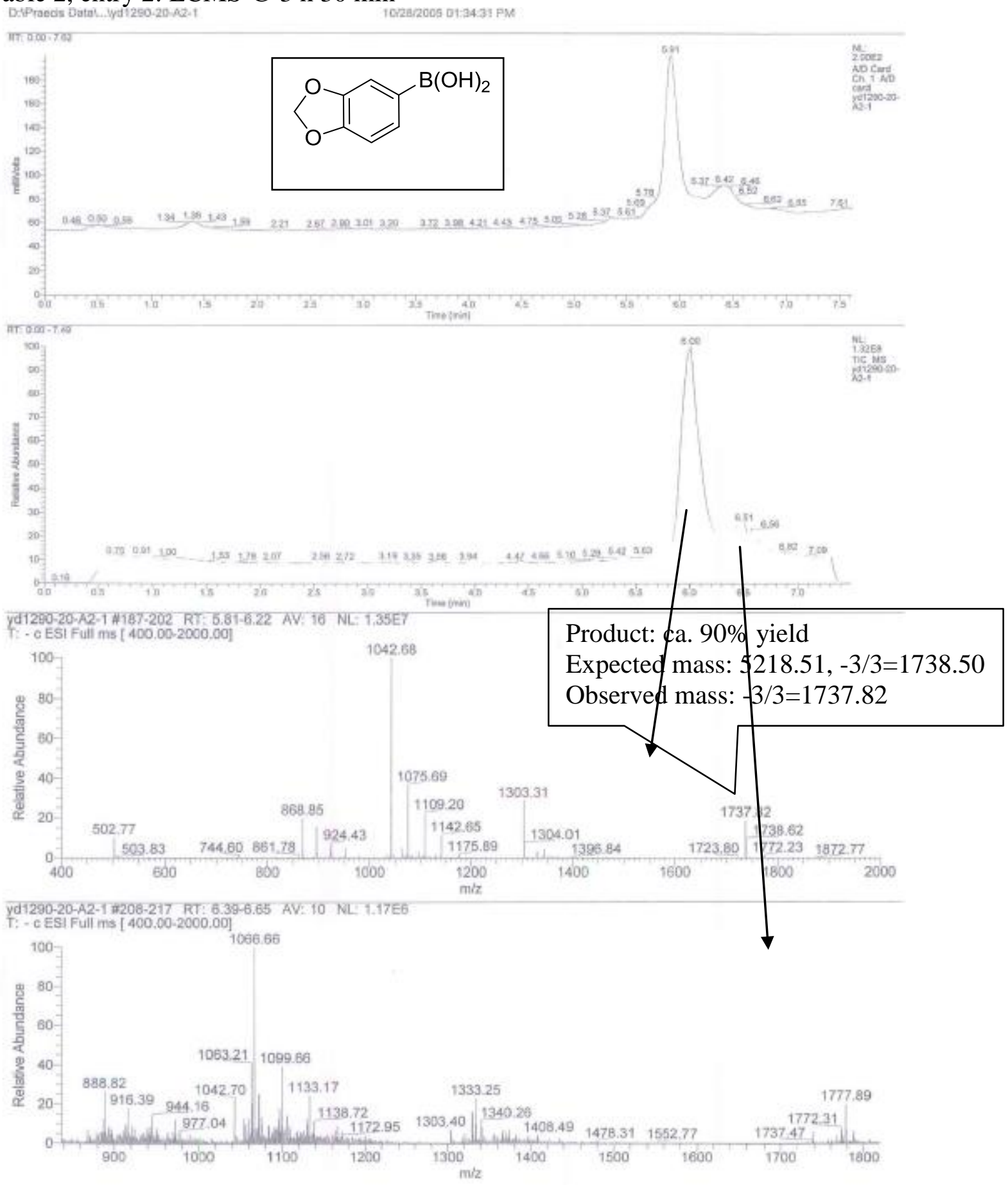


Table 2, entry 3: LCMS @ 3 h 25 min after first addition

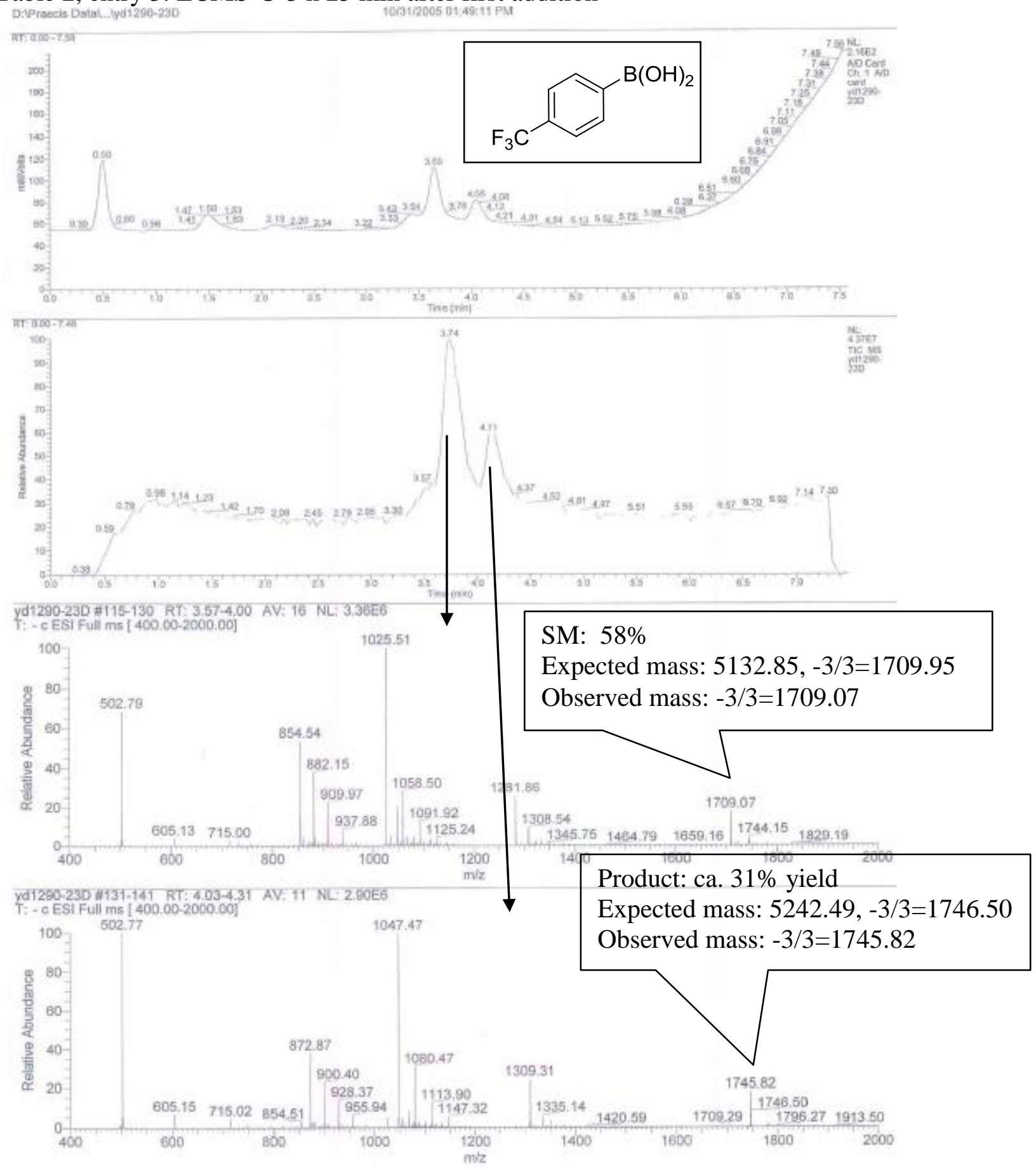


Table 2, entry 3: LCMS @ 12 h after second addition
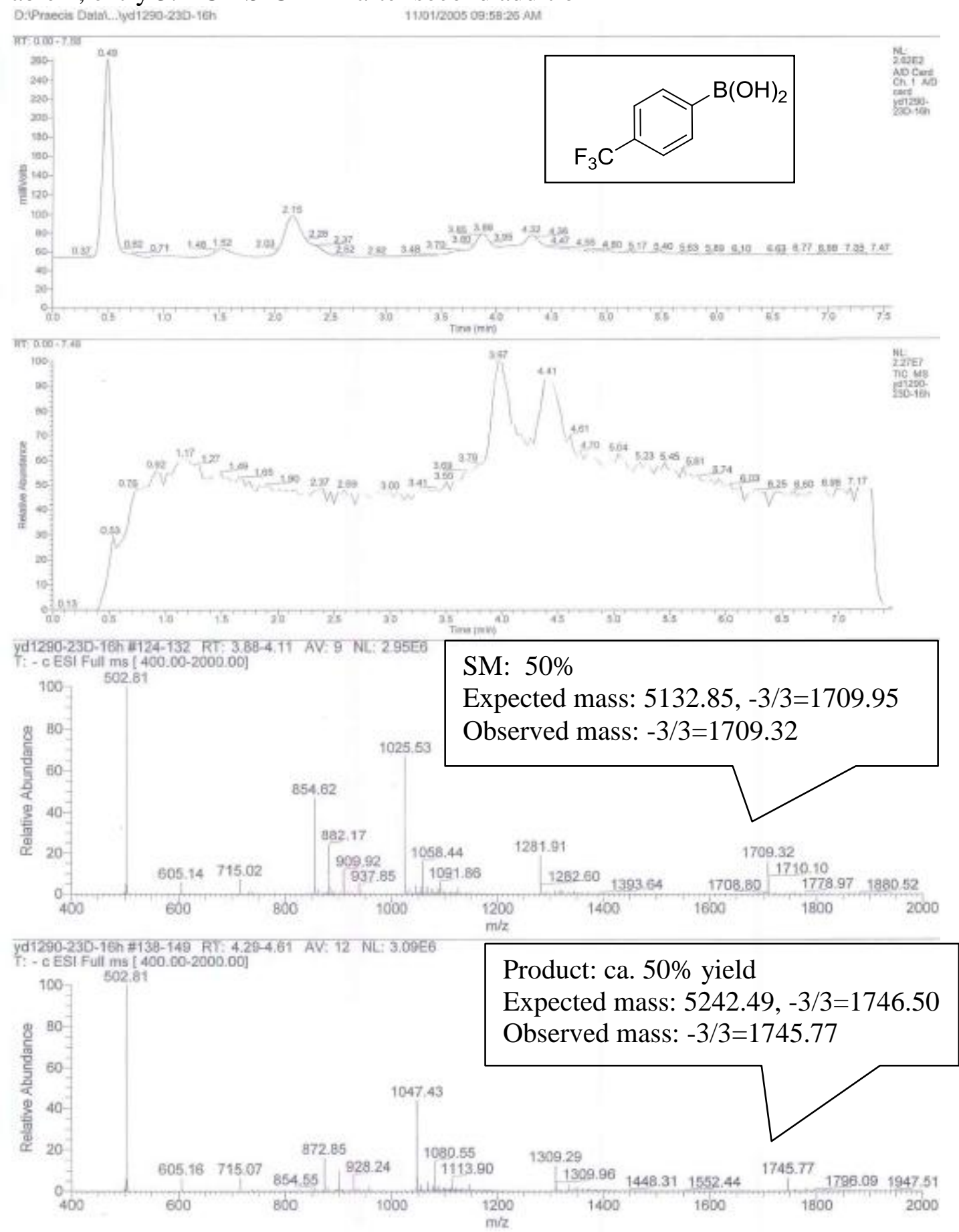
Table 2, entry 4: LCMS @ 3 h 25 min after first addition

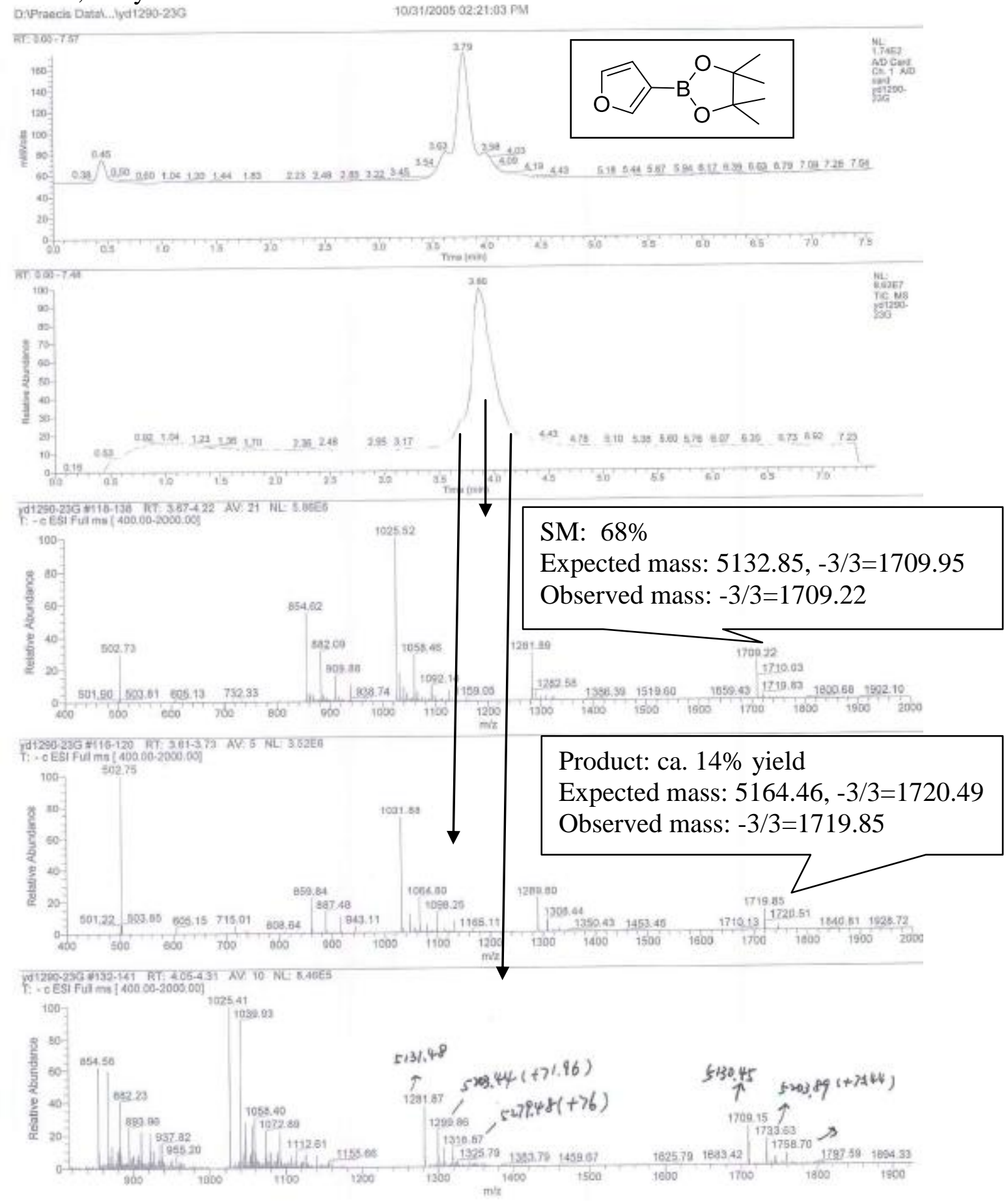


Table 2, entry 5: LCMS @ 3 h 25 min after first addition

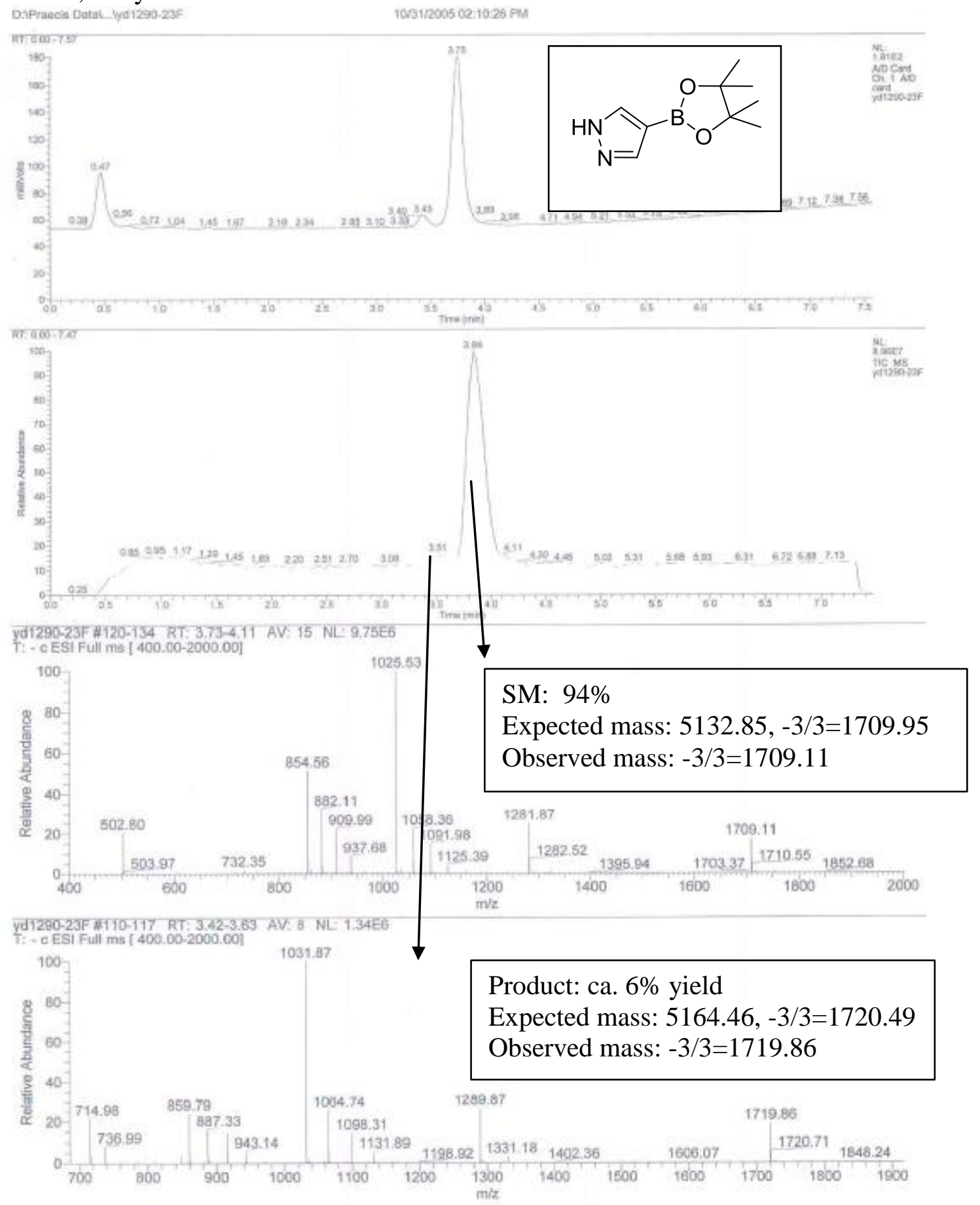


Table 2, entry 6: LCMS @ 3 h 25 min after first addition

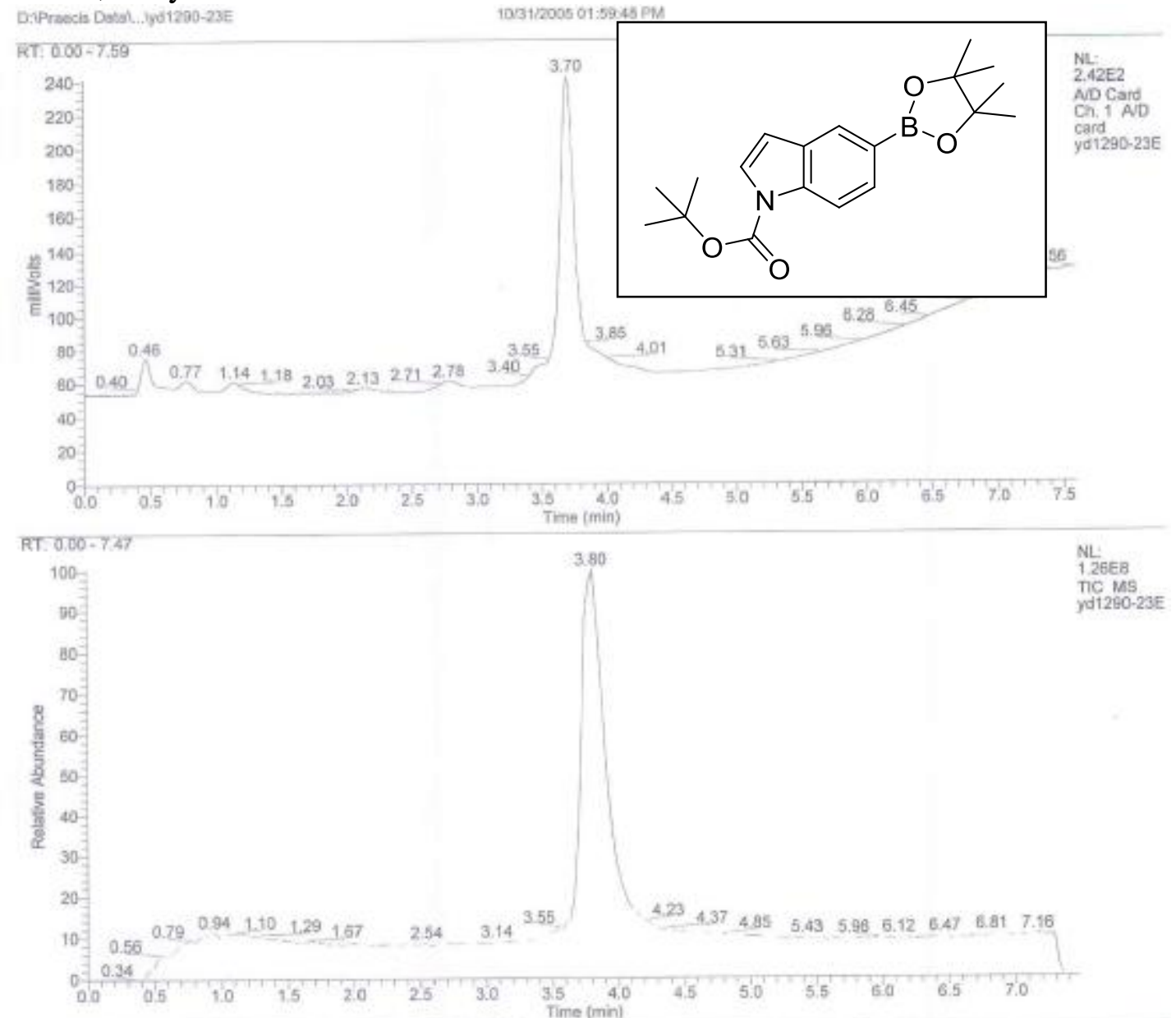

yd1290-23E

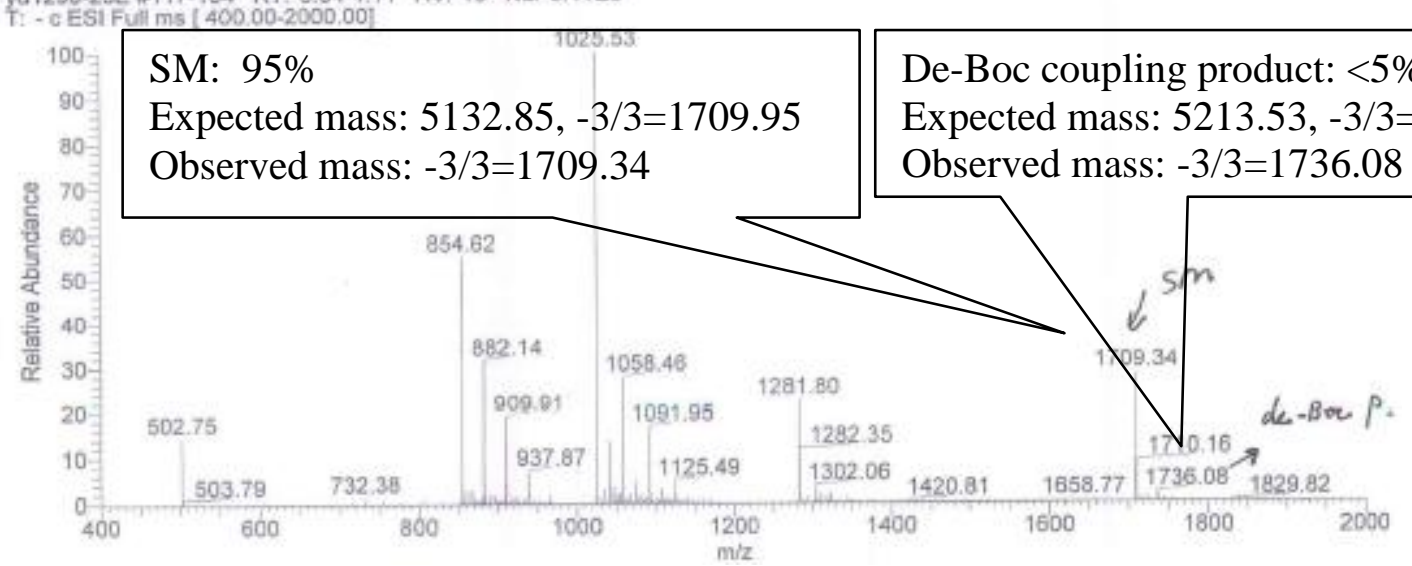


Table 2, entry 7: LCMS @ 3 h 25 min after first addition
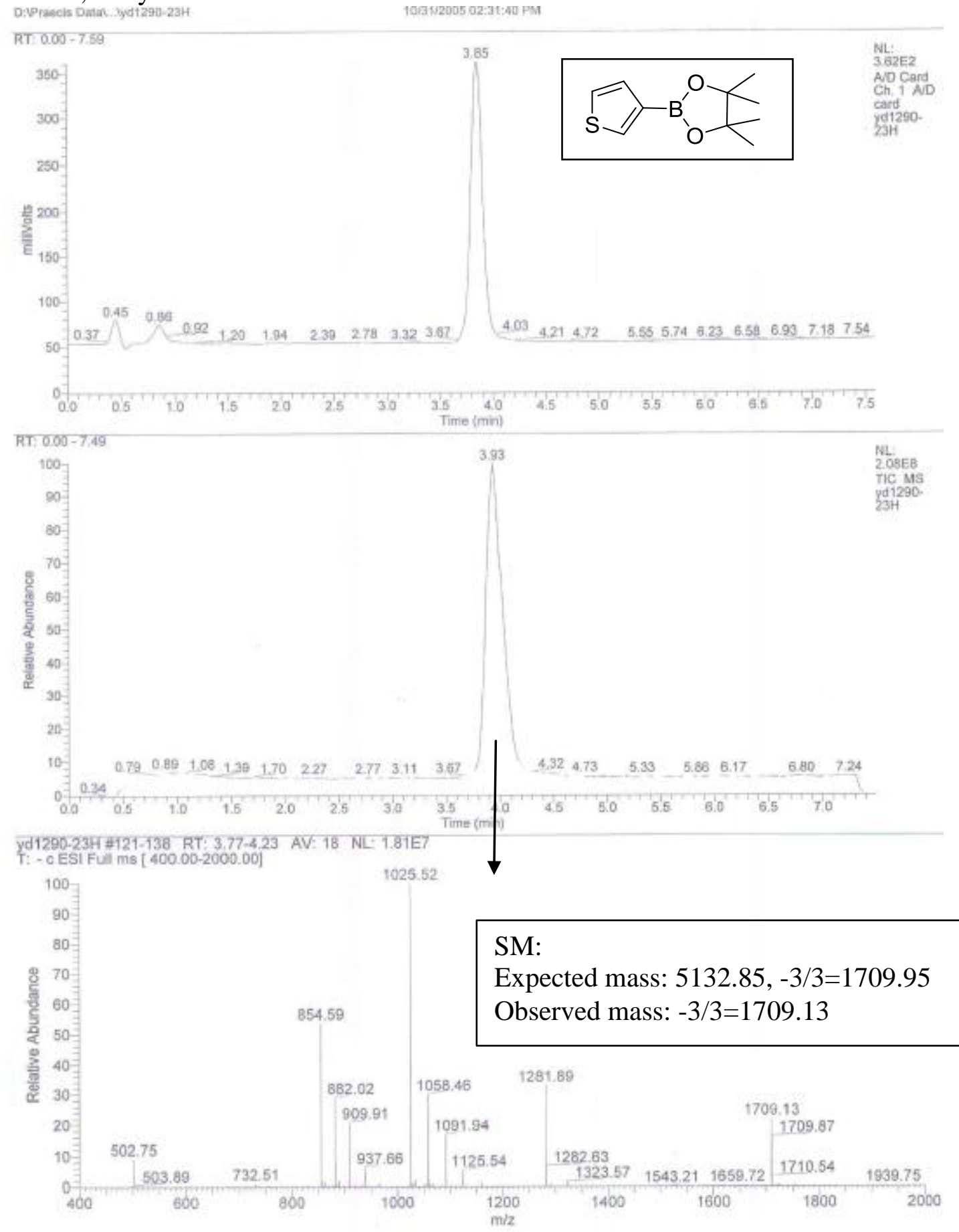
General procedure for the coupling of HP-3 with boronates using Pd/ligand 1 (Scheme 2).

Condition (a) A $1.5 \mathrm{mM}$ solution of HP-3 in water ( $10 \mathrm{nmol}, 6.7 \mu \mathrm{L})$ was added 40 equivalents of boronate $(0.5 \mu \mathrm{L}, 800 \mathrm{mM}$ in DMA $)$ and 80 equivalents of $\mathrm{Cs}_{2} \mathrm{CO}_{3}(1 \mu \mathrm{L}, 800 \mathrm{mM}$ in water), followed by 2 equivalents of ligand $1\left(2 \mu \mathrm{L}, 20 \mathrm{mM}\right.$ in water) and 1 equivalent of $\mathrm{Pd}(\mathrm{OAc})_{2}$ (1 $\mu \mathrm{L}, 10 \mathrm{mM}$ in $\mathrm{CH}_{3} \mathrm{CN}$ ). The reaction was allowed to proceed at $80{ }^{\circ} \mathrm{C}$ for $3.5 \mathrm{hrs}$.

Condition (b) A $1 \mathrm{mM}$ solution of HP-3 in water $(10 \mathrm{nmol}, 9 \mu \mathrm{L})$ was added 40 equivalents of boronate $(0.5 \mu \mathrm{L}, 800 \mathrm{mM}$ in DMA $)$ and 80 equivalents of $\mathrm{Cs}_{2} \mathrm{CO}_{3}(1 \mu \mathrm{L}, 800 \mathrm{mM}$ in water), followed by 1 equivalent of pre-mixed solution of $\mathrm{Pd}_{2}(\mathrm{dba})_{3}$ and ligand $1(\mathrm{Pd} /$ ligand $1 / 2,8 \mathrm{mM}$ in $\mathrm{CH}_{3} \mathrm{CN} / \mathrm{DMA} / \mathrm{Tolune} \sim 1 / 2 / 1$ ). The reaction was allowed to proceed at $80^{\circ} \mathrm{C}$ (or $95{ }^{\circ} \mathrm{C}$ for heterocyclic boronates ) for $4 \mathrm{hrs}$.

HP-3: starting material used for the reactions with Pd/Ligand 1. 


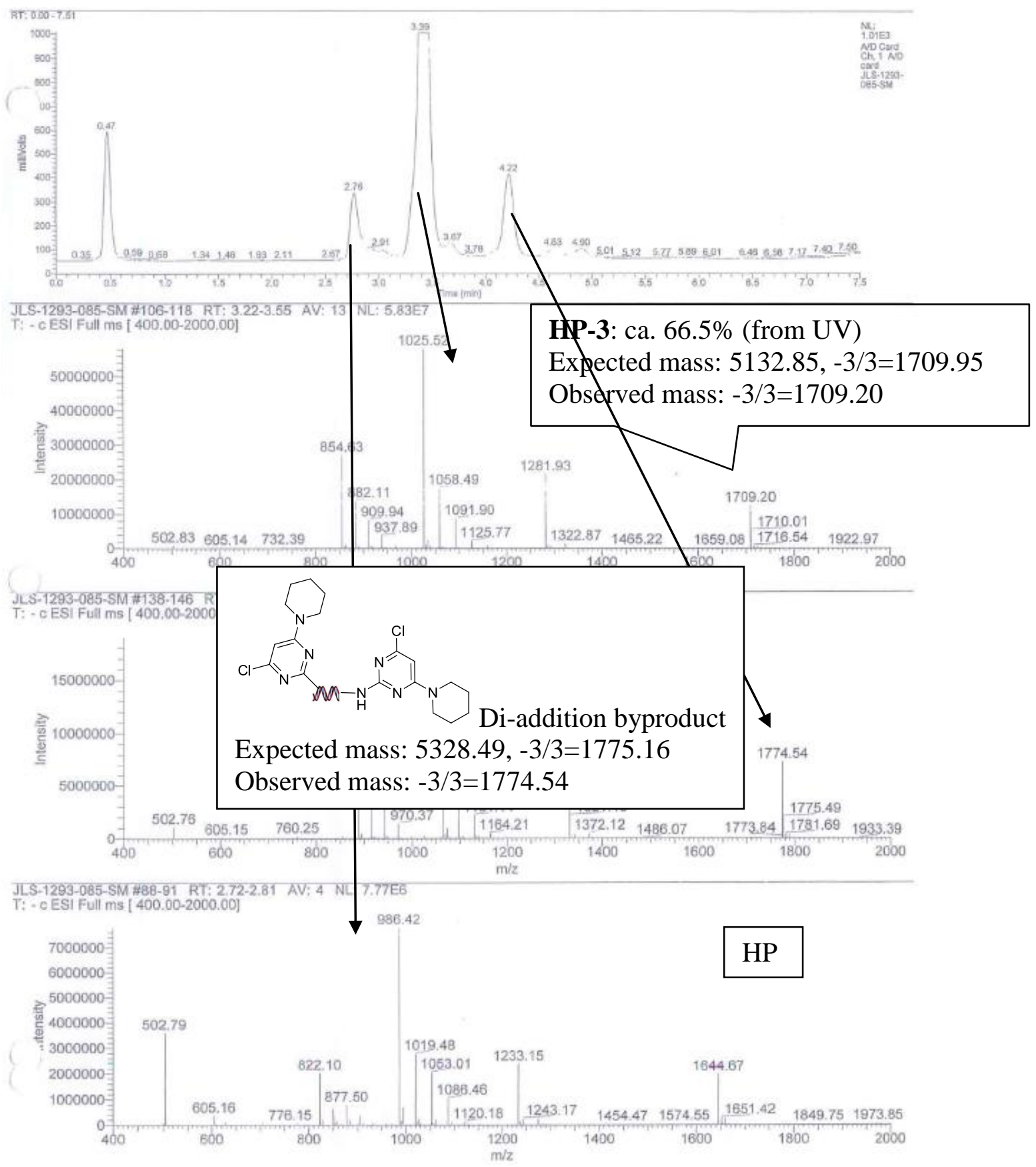


$\mathrm{Pd}(\mathrm{OAc})_{2} /$ ligand $\mathbf{1}$ :

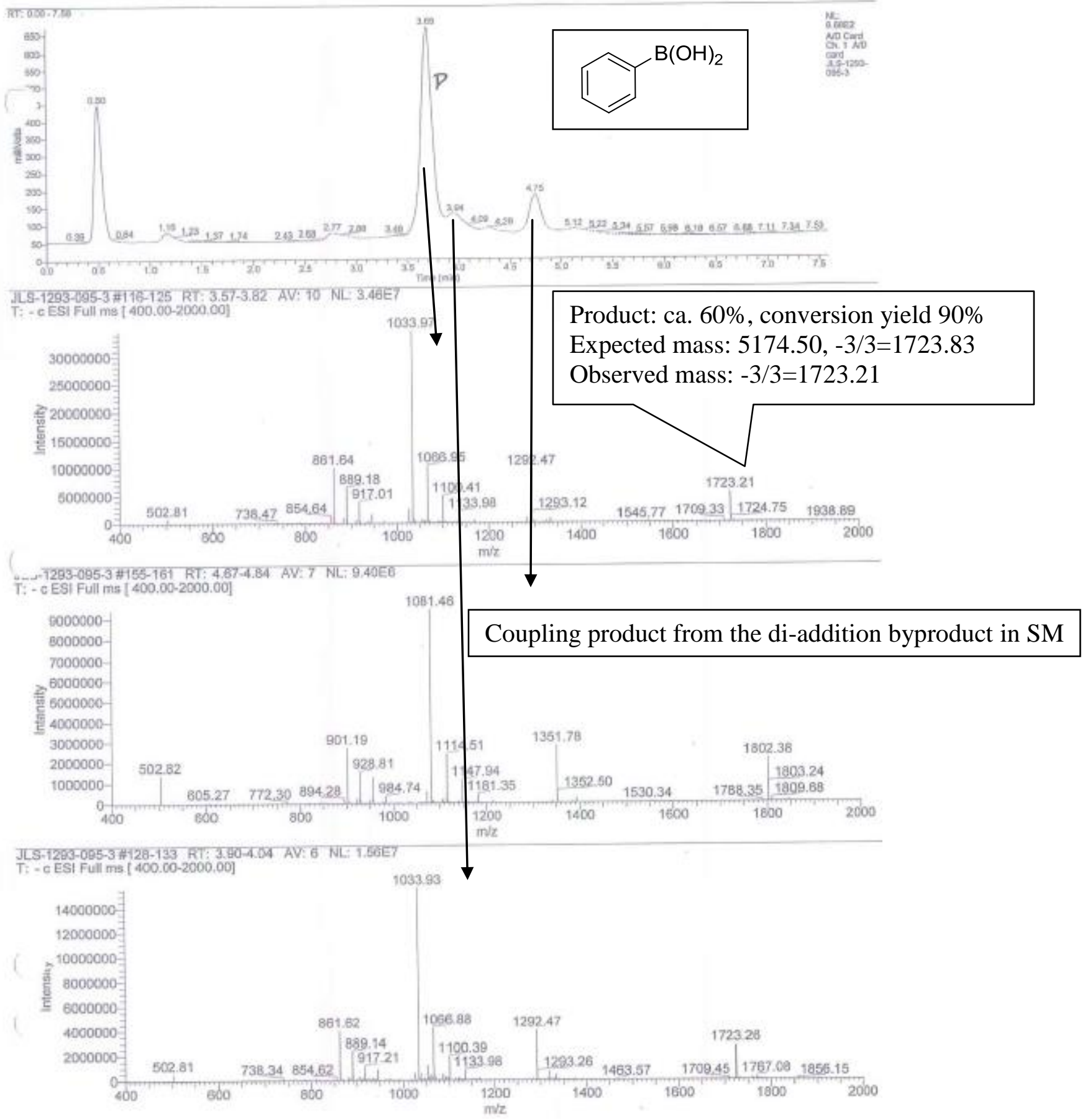


$\mathrm{Pd}(\mathrm{OAc})_{2} /$ ligand 1:

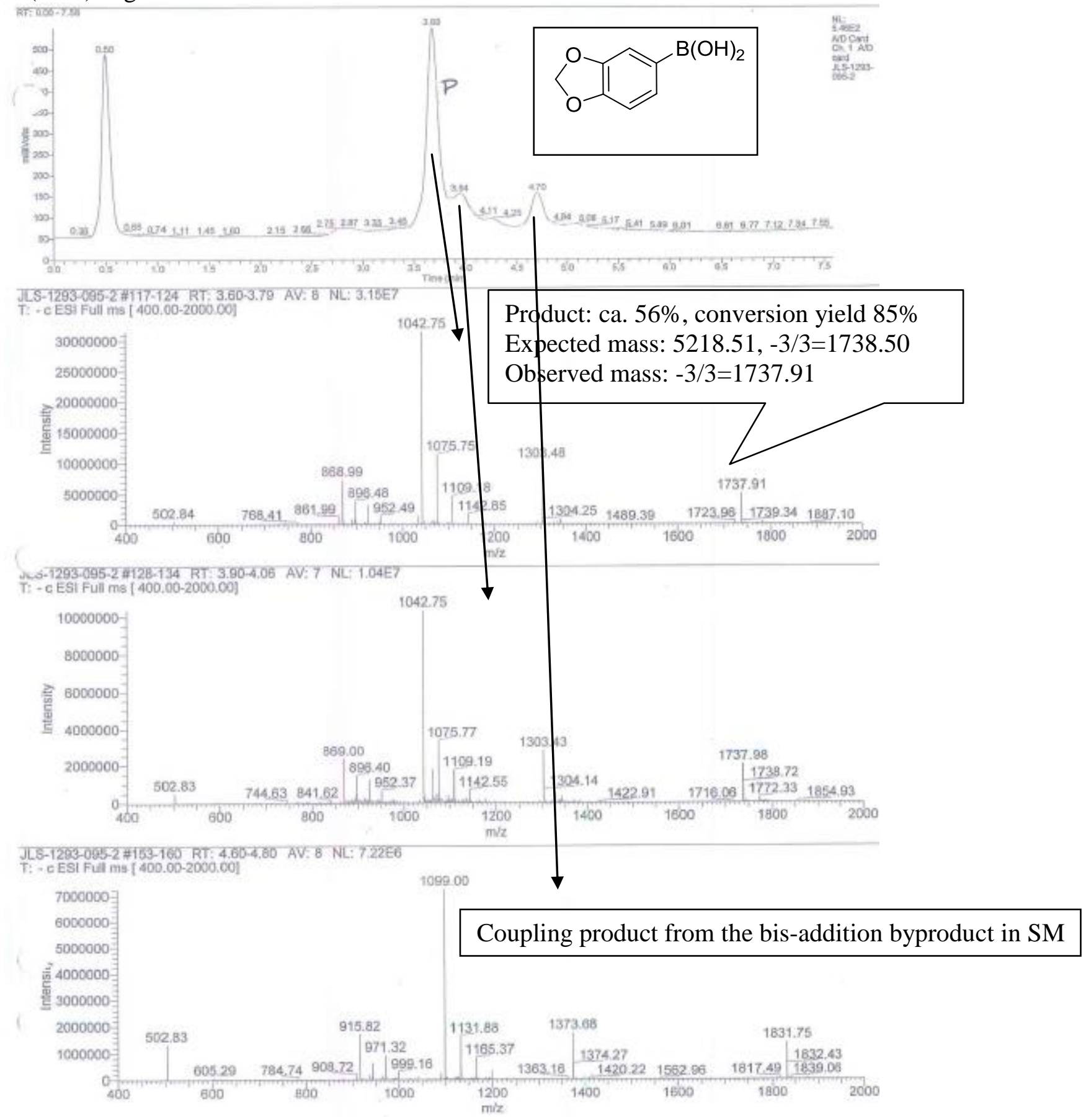


$\mathrm{Pd}(\mathrm{OAc})_{2} /$ ligand 1:

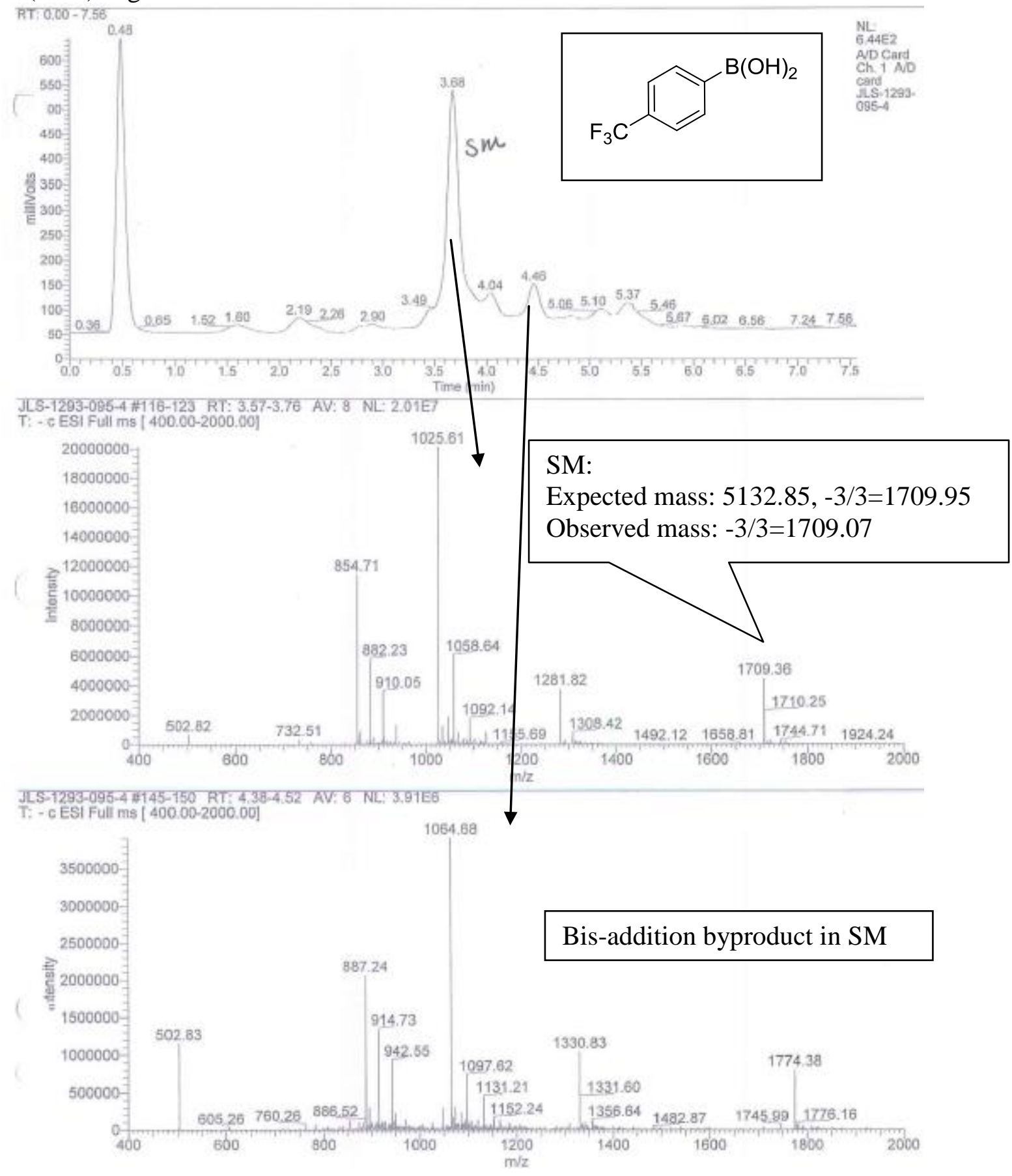




\section{$\mathrm{Pd}_{2}(\mathrm{dba})_{3} /$ ligand 1:}
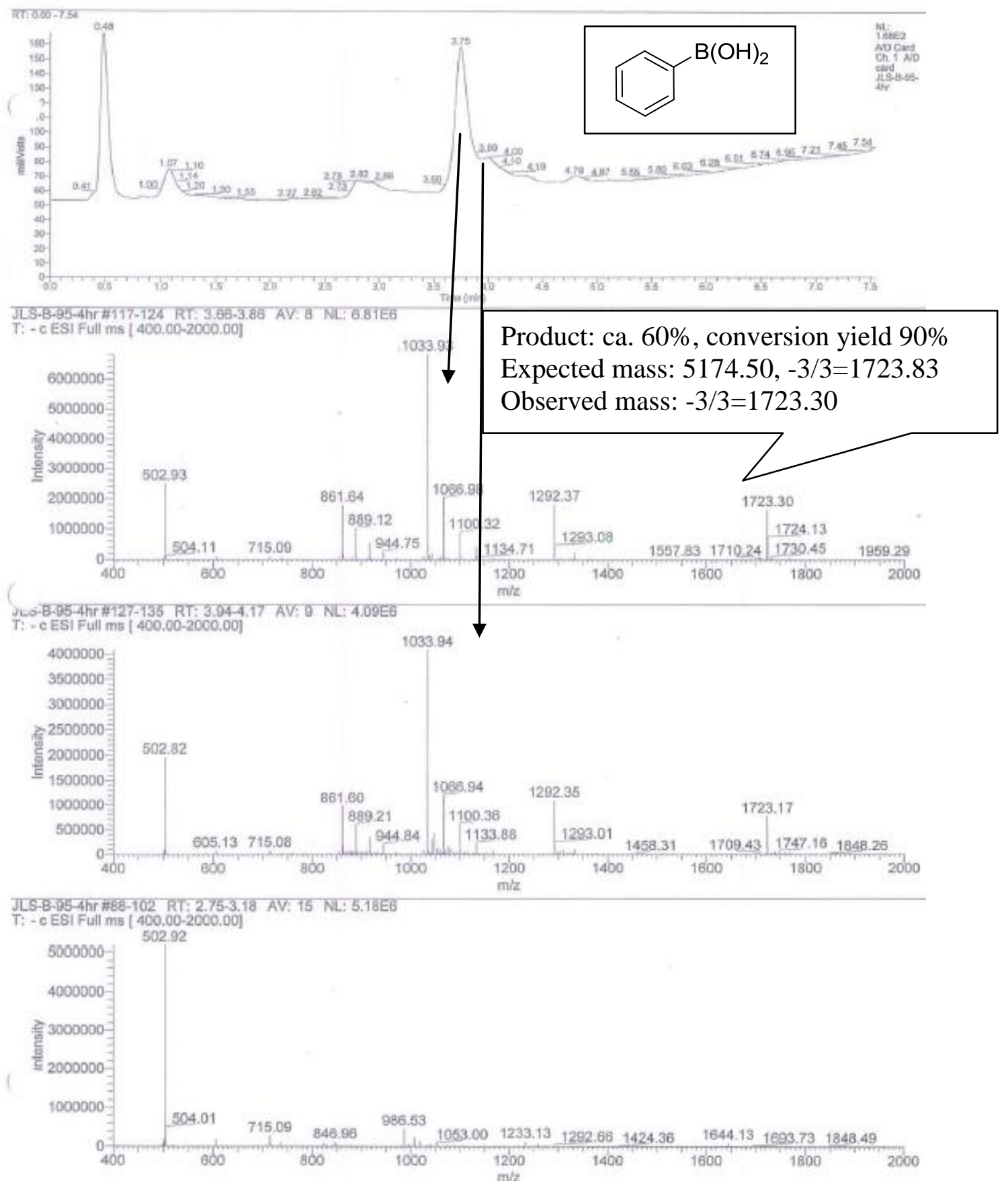


\section{$\mathrm{Pd}_{2}(\mathrm{dba})_{3} /$ ligand 1:}

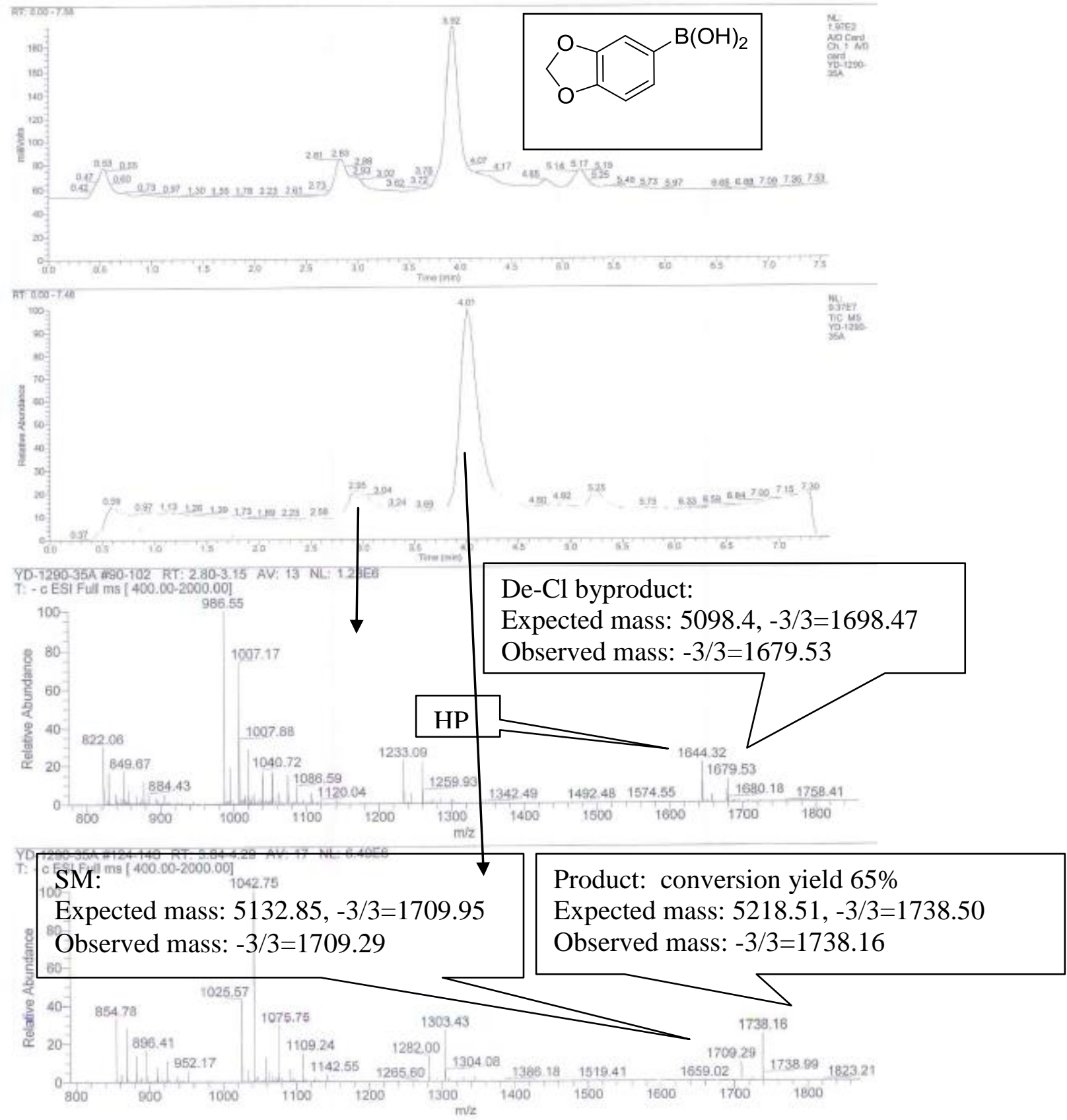


$\mathrm{Pd}_{2}(\mathrm{dba})_{3} /$ ligand $\mathbf{1}$ :

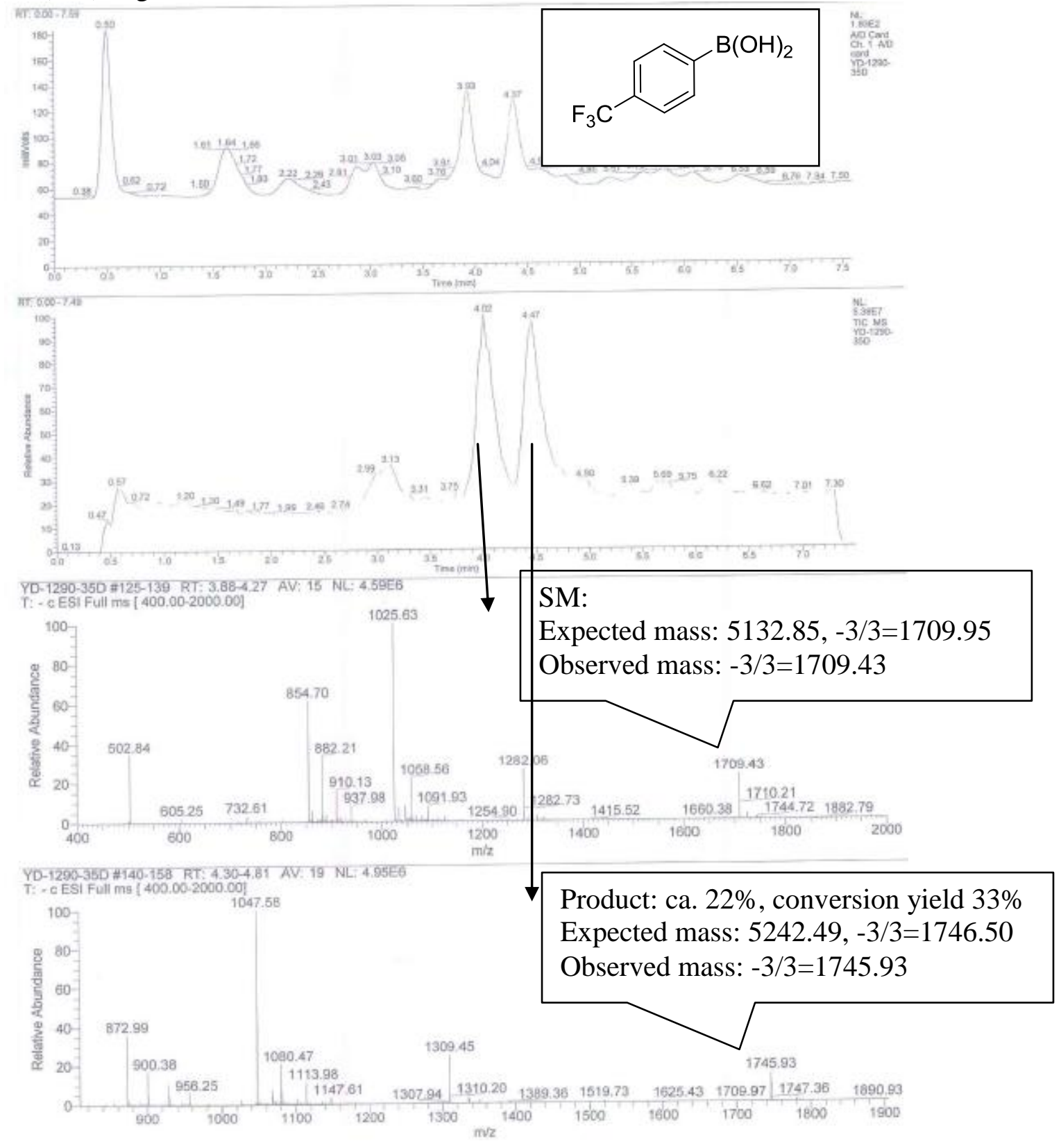




\section{$\mathrm{Pd}_{2}(\mathrm{dba})_{3} /$ ligand 1:}

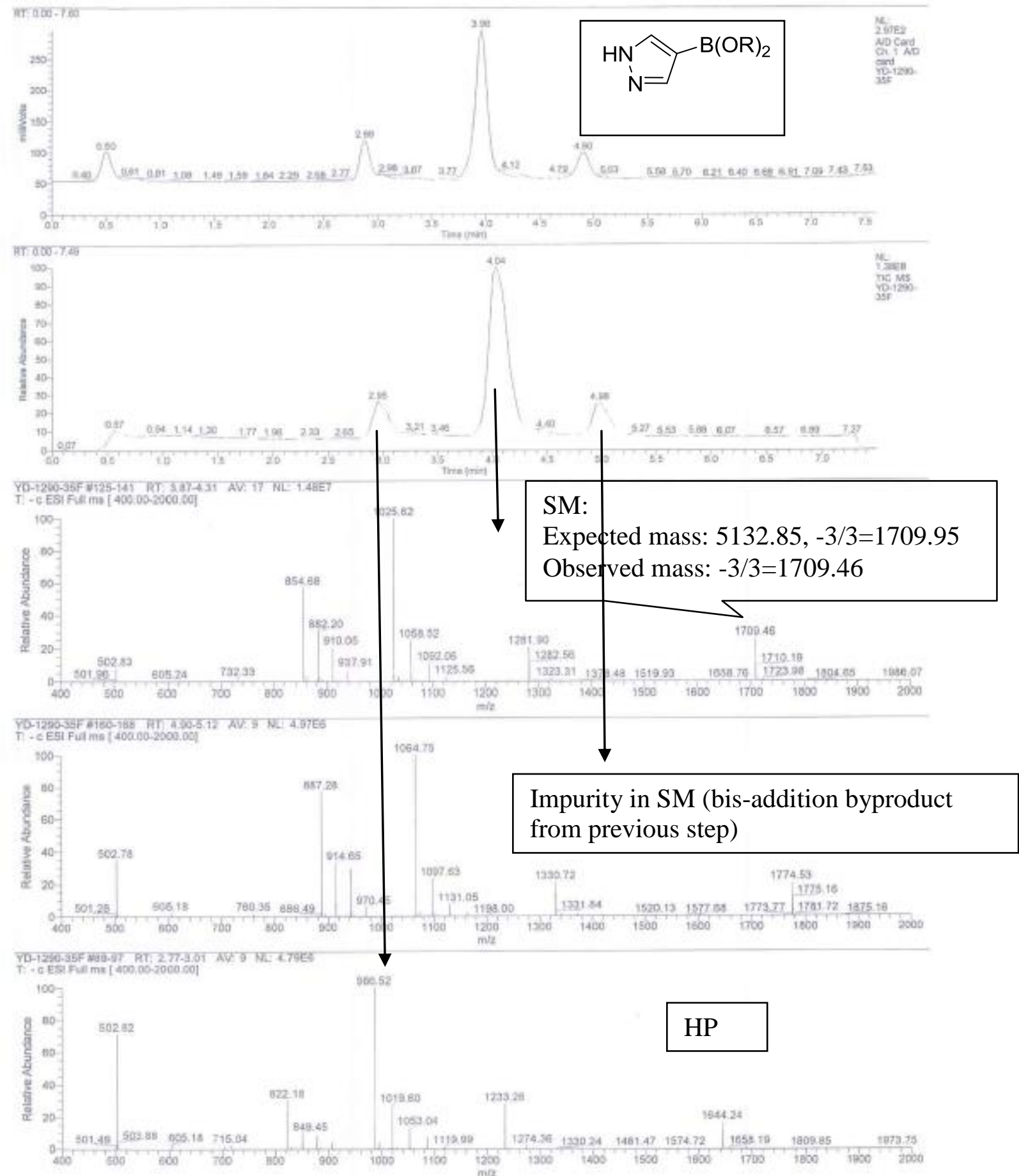




\section{$\mathrm{Pd}_{2}(\mathrm{dba})_{3} /$ ligand 1:}

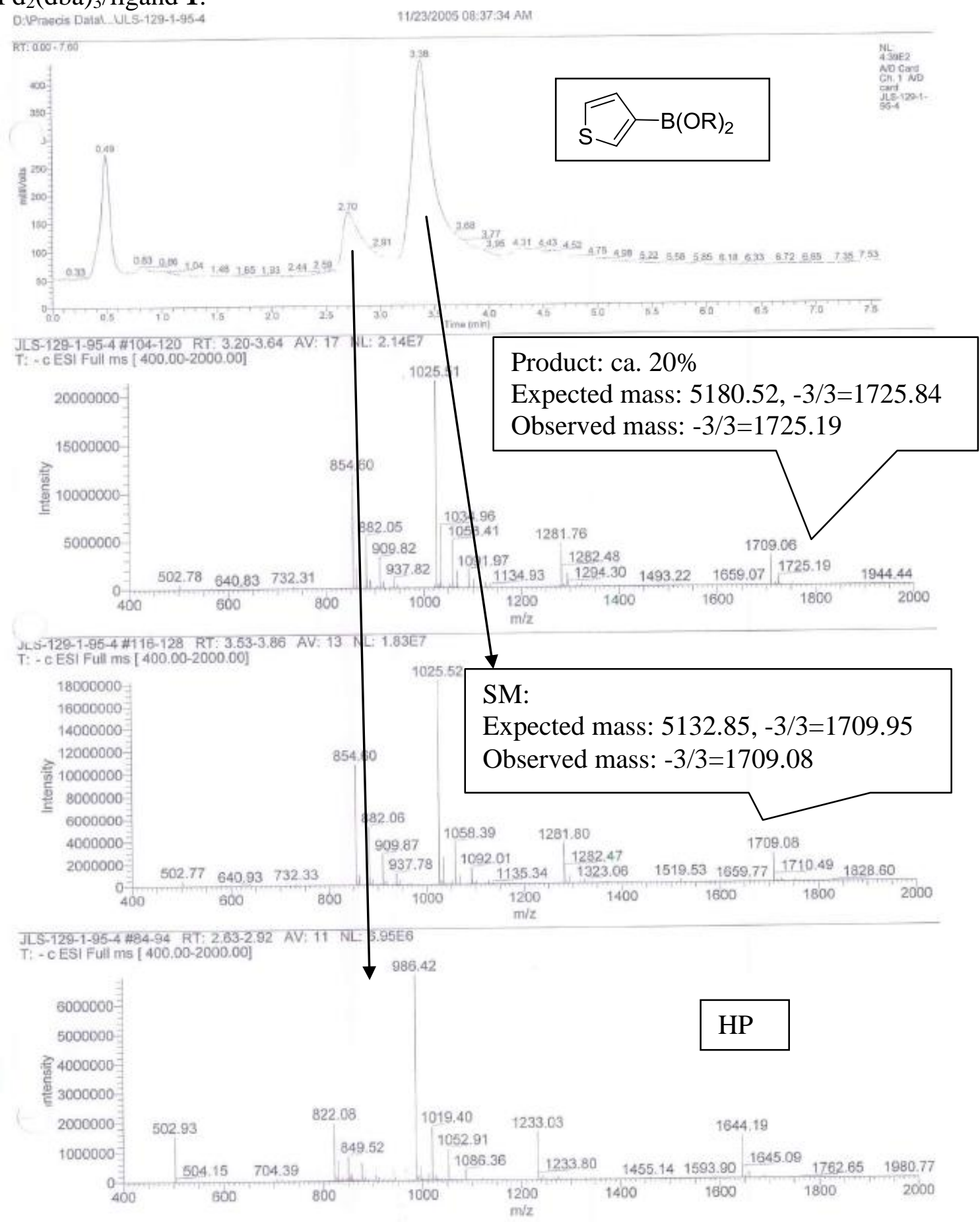


General procedure for the coupling of HP-3 with boronates in Table 3 using POPd or POPd2/Ligand 1.

A $1.33 \mathrm{mM}$ solution of HP-3 in water $(10 \mathrm{nmol}, 7.5 \mu \mathrm{L})$ was added 40 equivalents of boronate $(0.5 \mu \mathrm{L}, 800 \mathrm{mM}$ in DMA) and 80 equivalents of $\mathrm{KOH}(1 \mu \mathrm{L}, 800 \mathrm{mM}$ in water), followed by 1 equivalent of $\mathrm{Pd} /$ ligand 1 (1/2) solution, which was prepared by mixing 2 equivalents of ligand 1 $(0.5 \mu \mathrm{L}, 40 \mathrm{mM}$ in water) and 1 equivalent of POPd or POPd $2(0.5 \mu \mathrm{L}, 20 \mathrm{mM}$ in DMA $)$. The reaction was allowed to proceed at $100{ }^{\circ} \mathrm{C}$ for 4 hours.

HP-3: starting material used for the reactions with POPd or POPd2/Ligand 1.

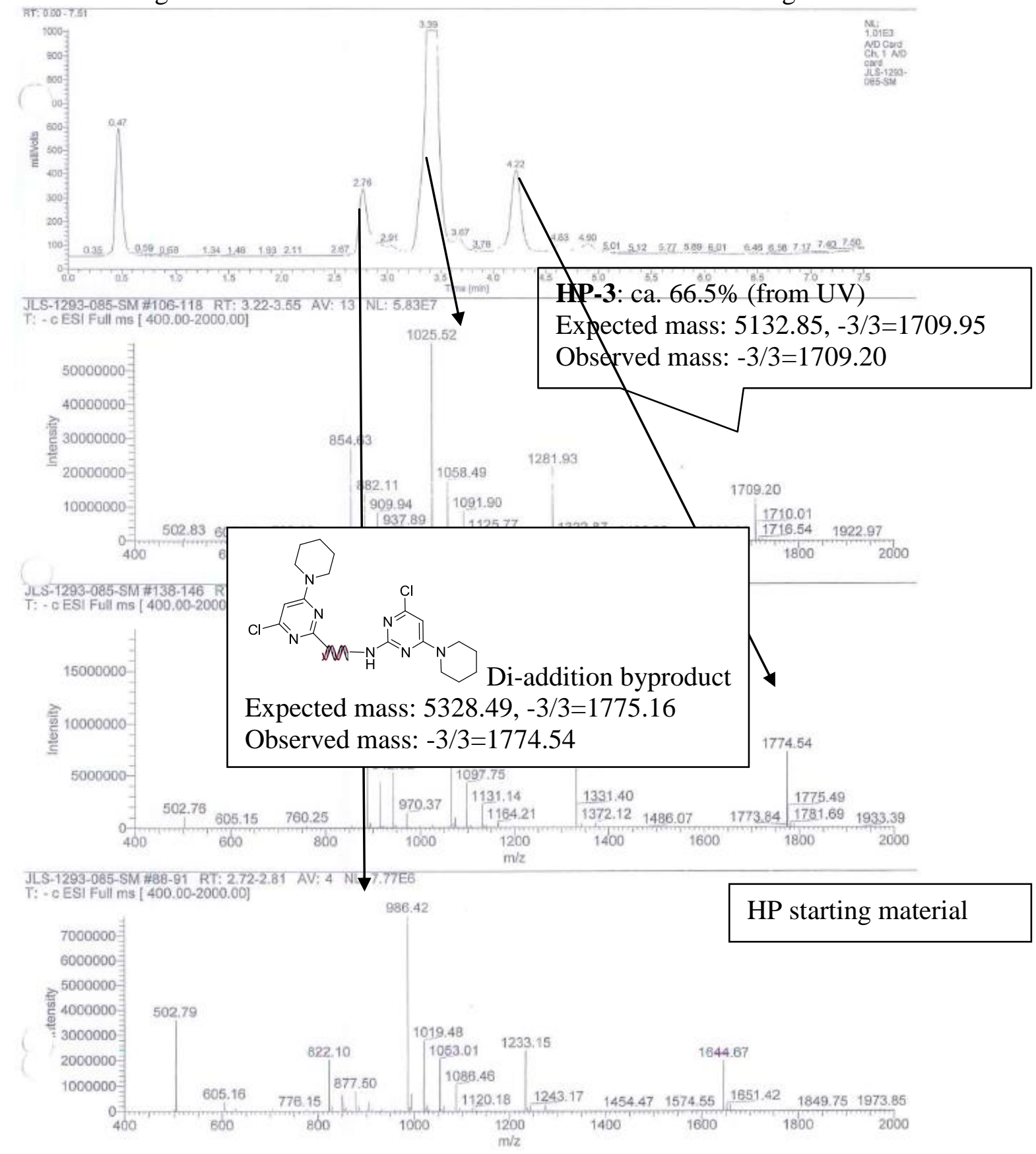


Table 3, entry 1A:

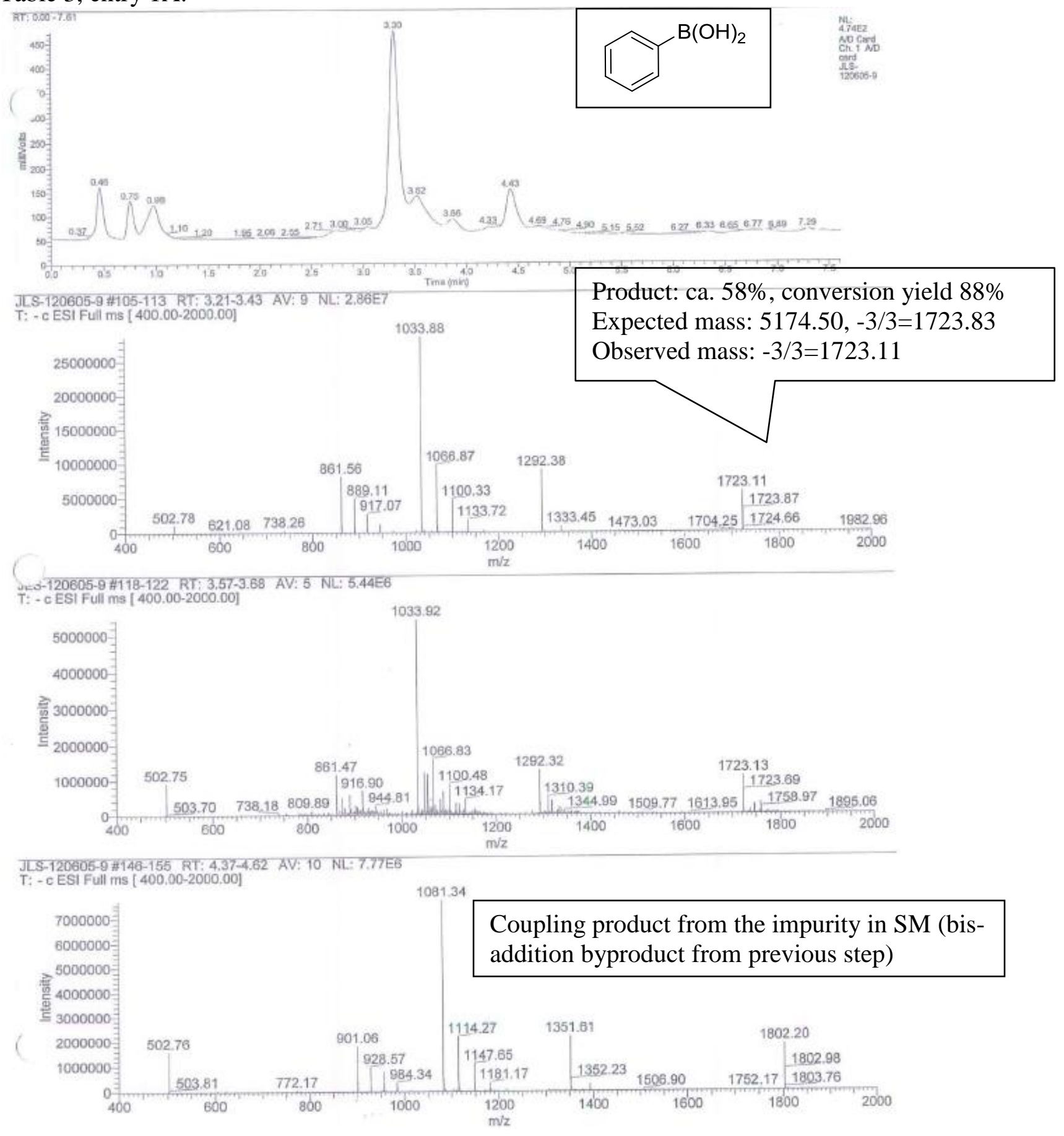


Table 3, entry 1B:

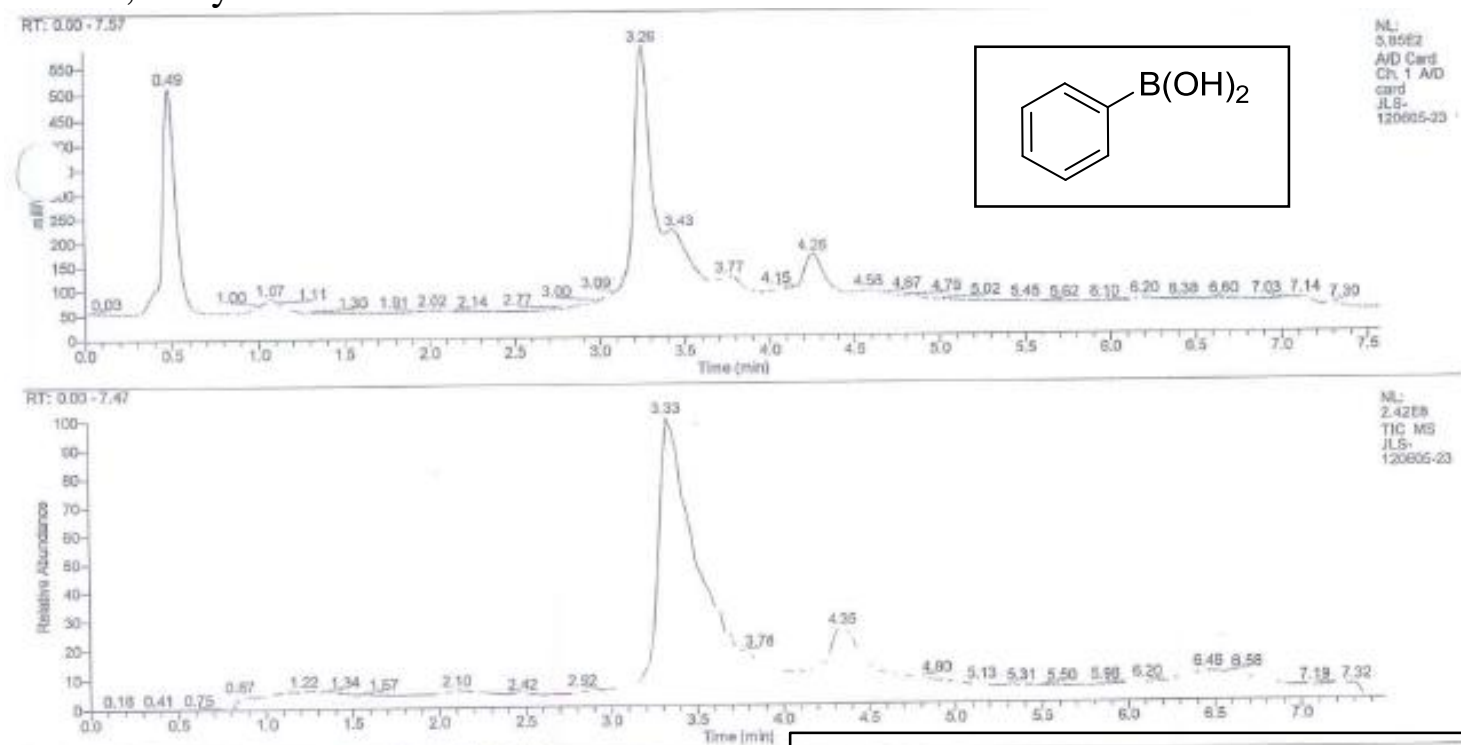

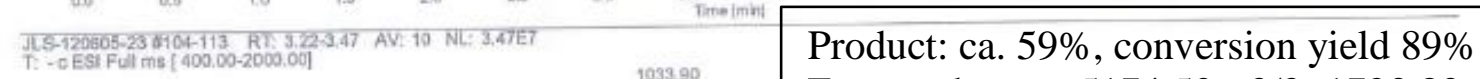

Expected mass: $5174.50,-3 / 3=1723.83$

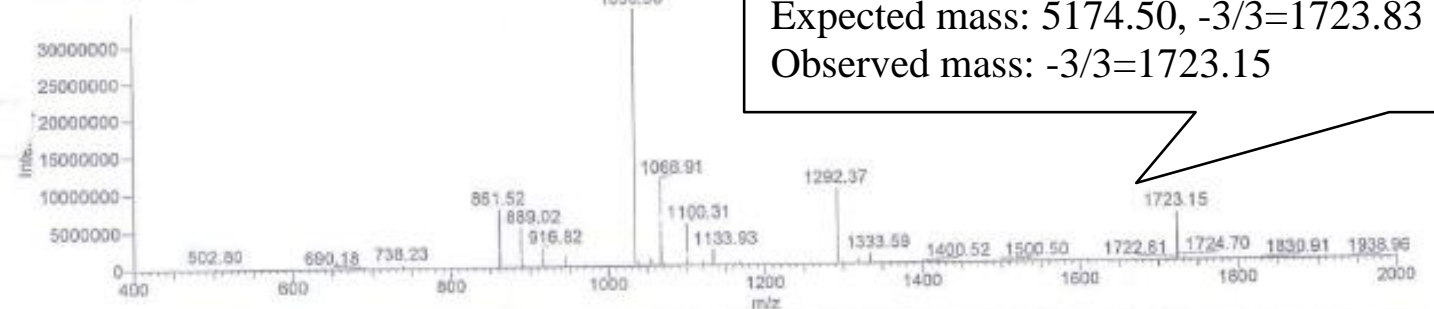

JLS.12005-25

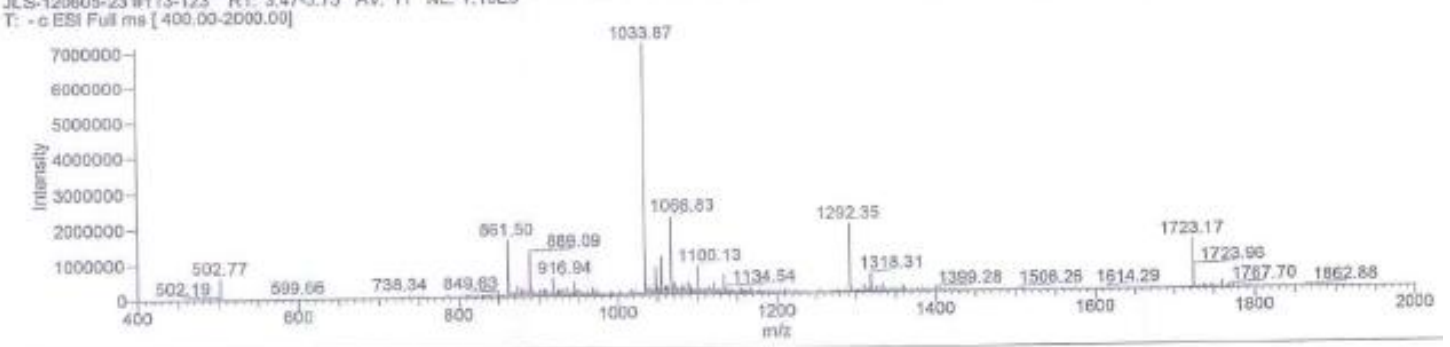

JLS-120605-23 H-140-148 RI: $424-4,49$ AV: 9 NL: B.4TEE

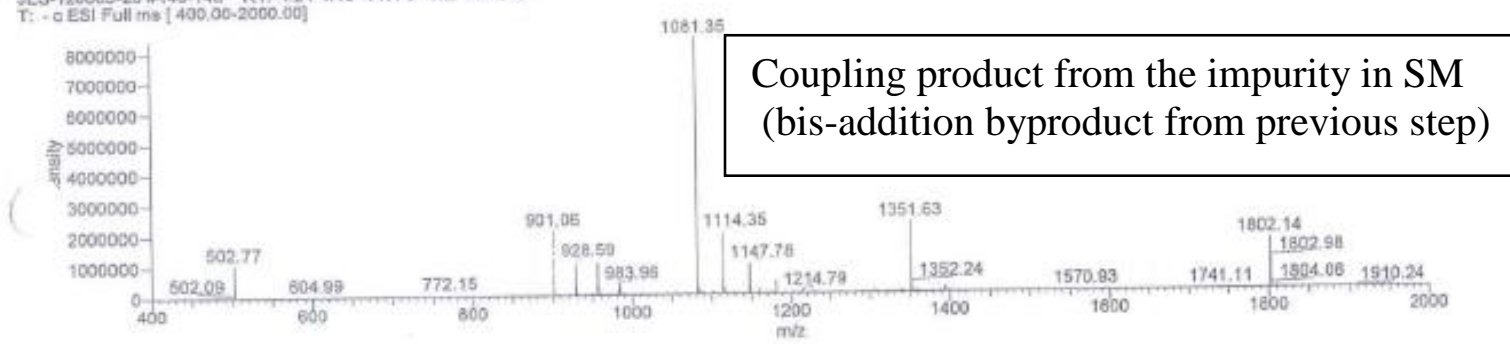


Table 3, entry 2A:
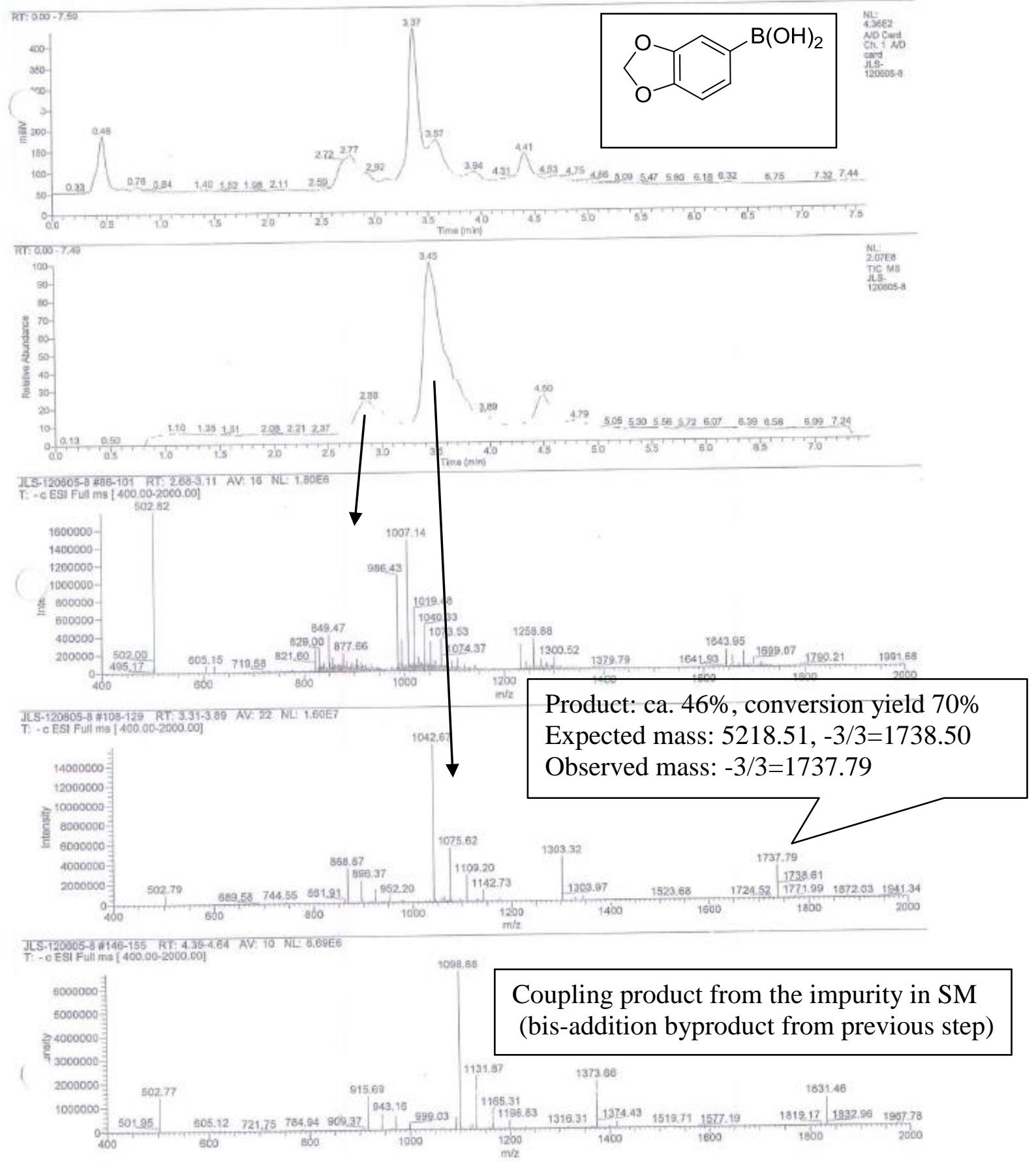
Table 3, entry 2B:

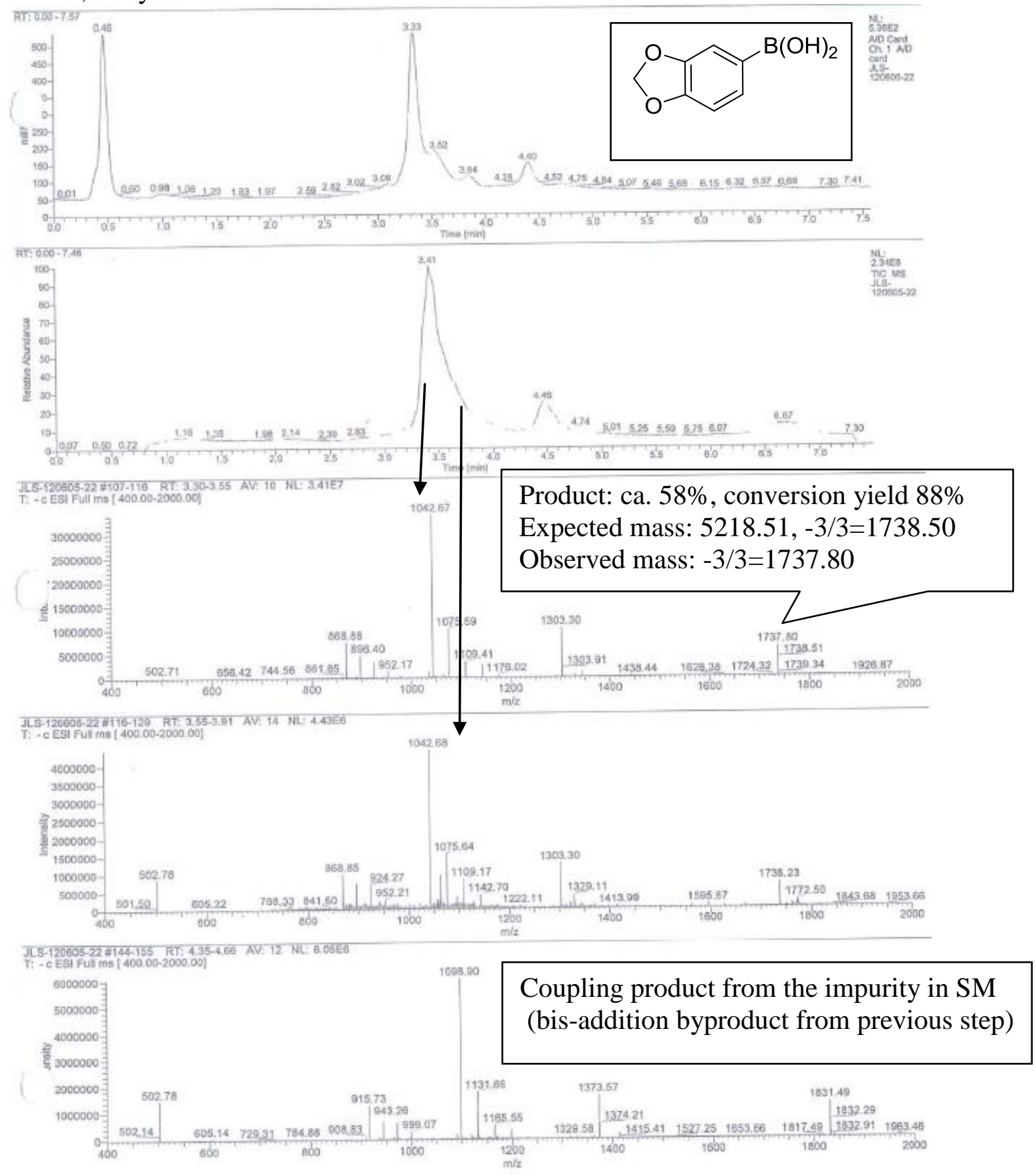


Table 3, entry 3A:

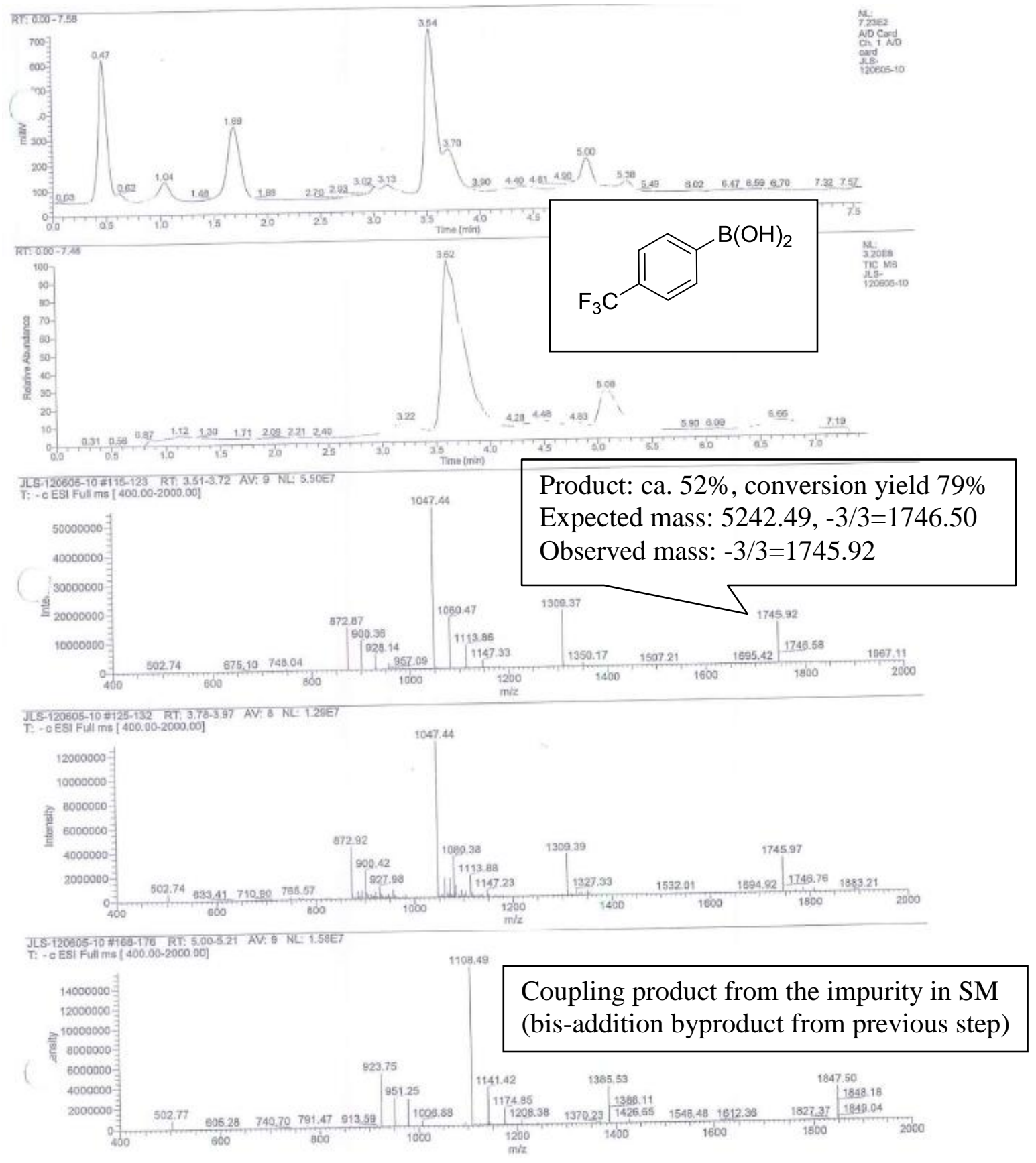


Table 3, entry 3B:

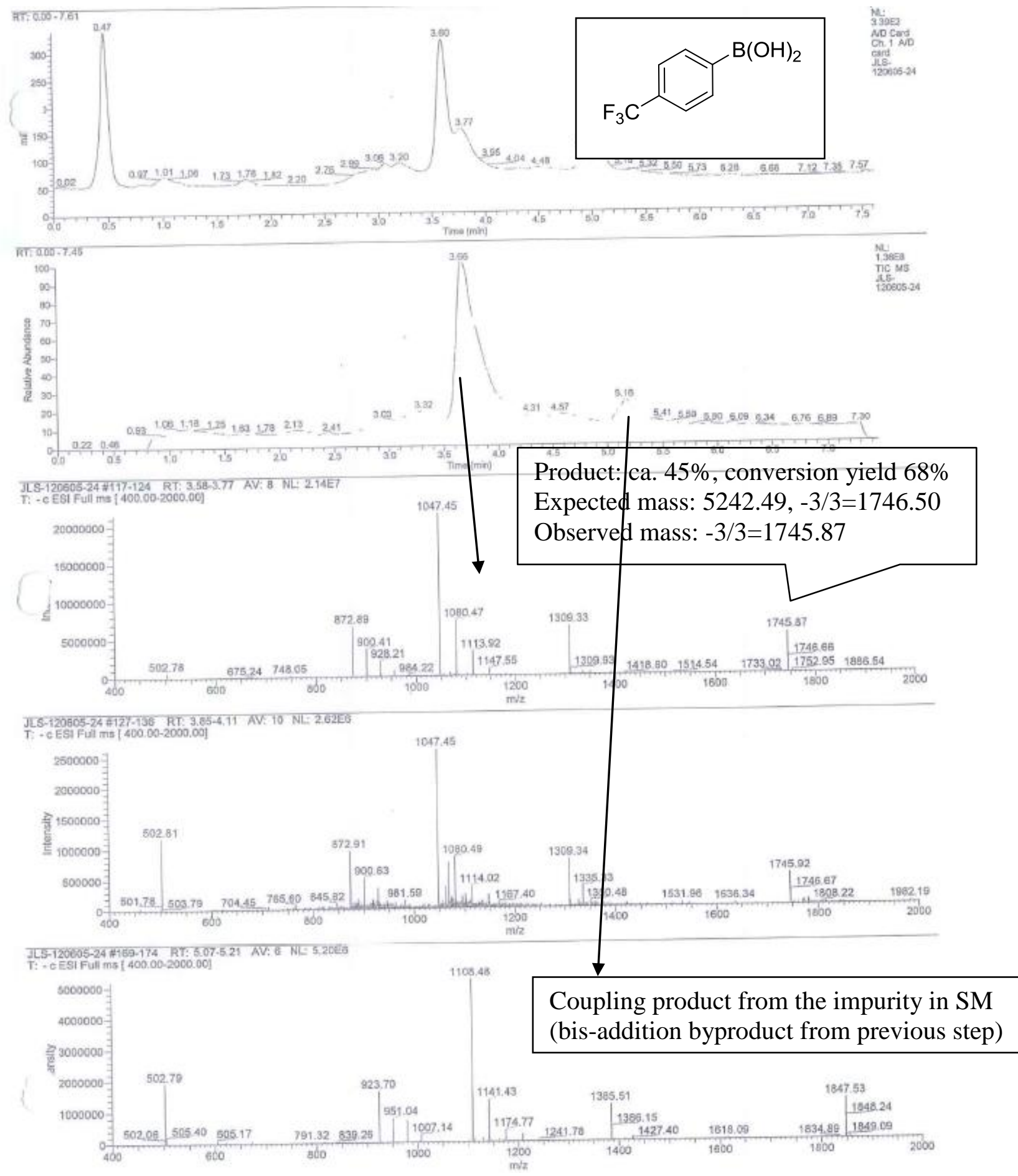


Table 3, entry 4A:
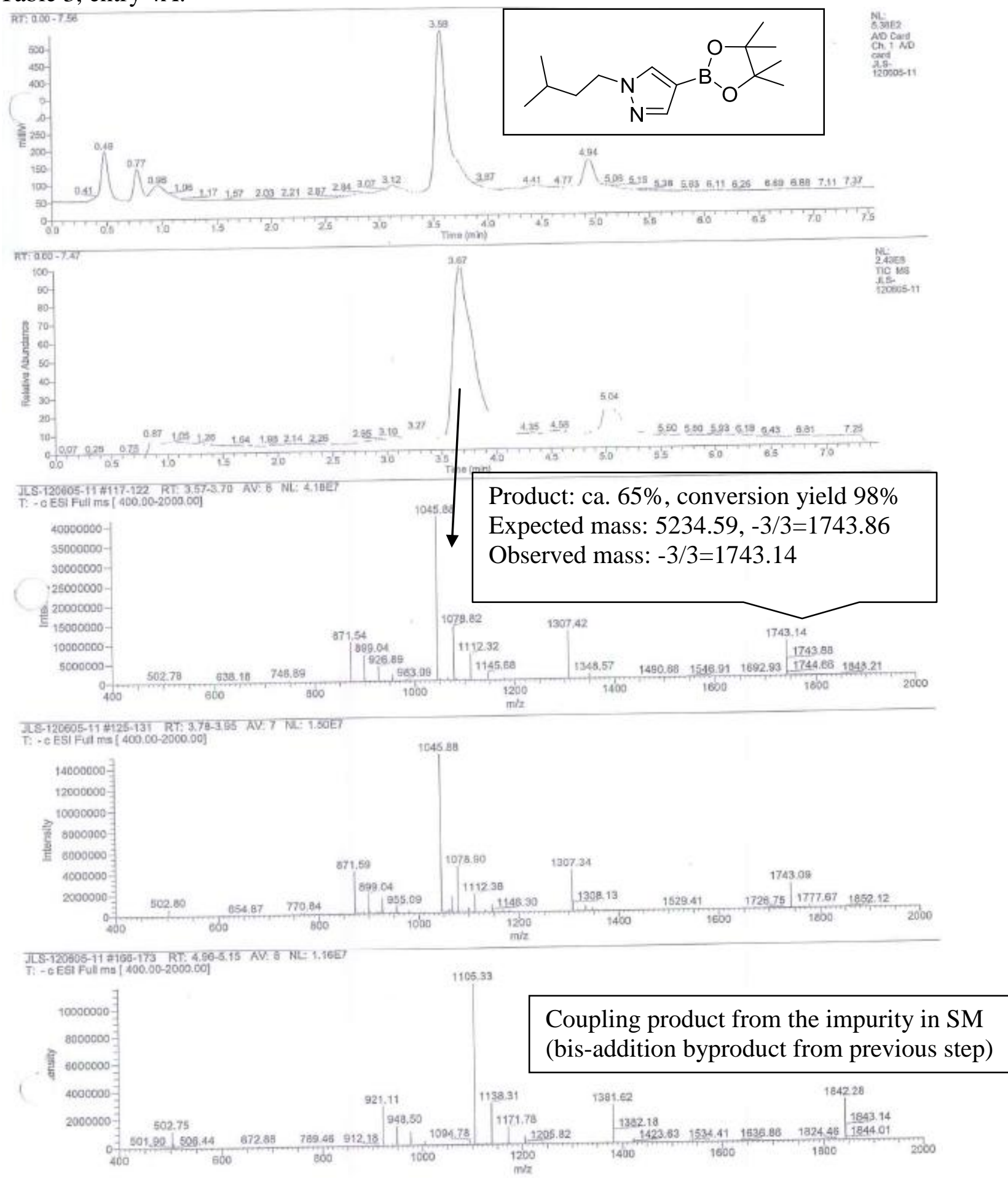
Table 3, entry 4B:
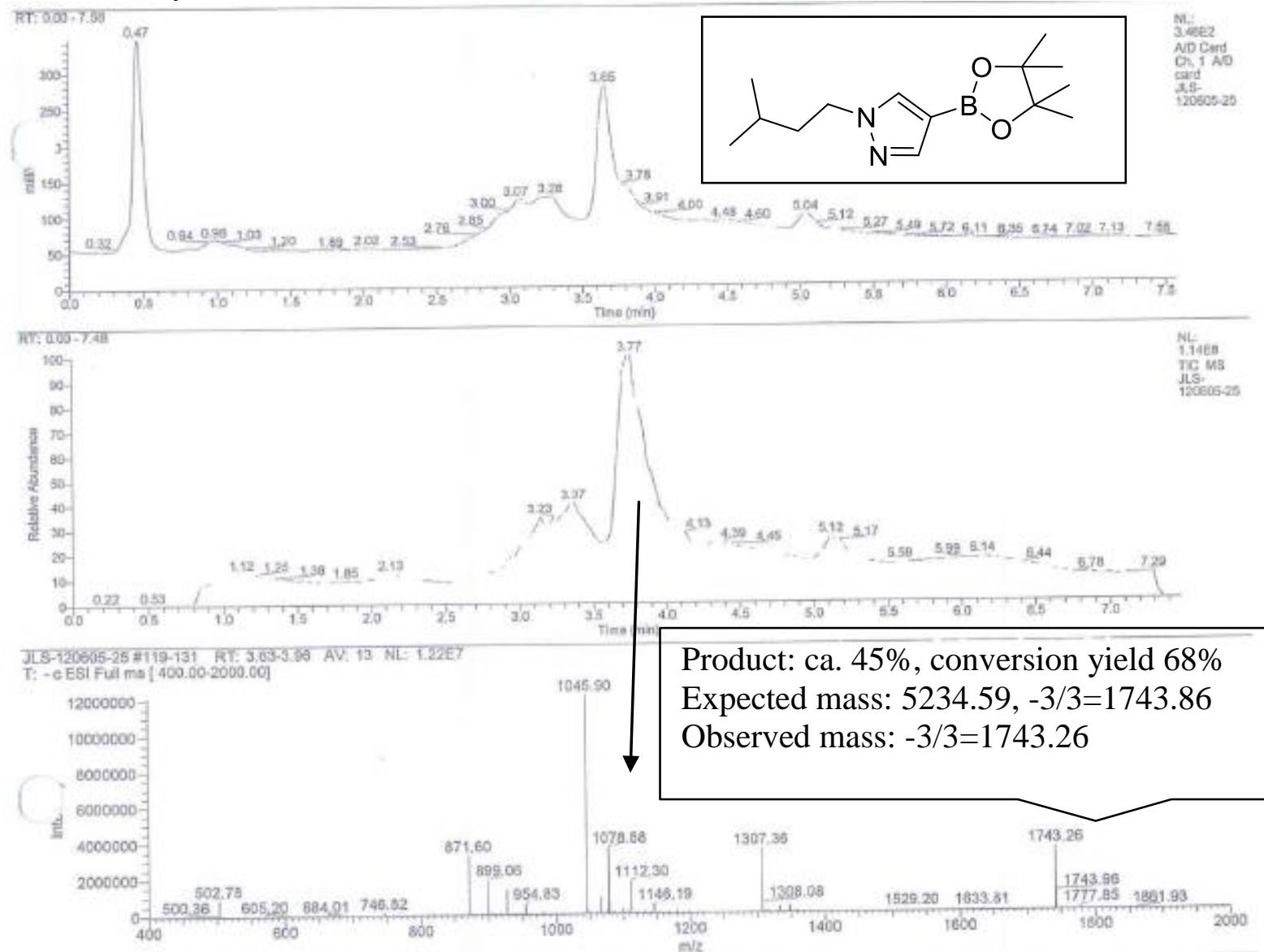

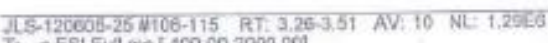

T: $\rightarrow 0$ ESI FuA ms [ $400,00-2000,00]$

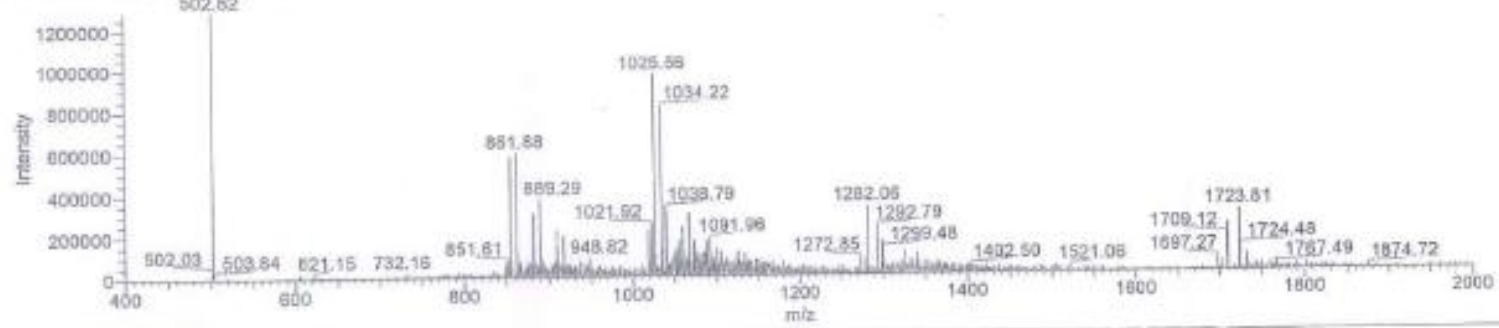

J[5-120605-25 $\$ 95.905$ RT $297-323$ AV ND NE 1.6866

$\mathrm{T}$. c ESI Full ms $[400,00-2000.00]$

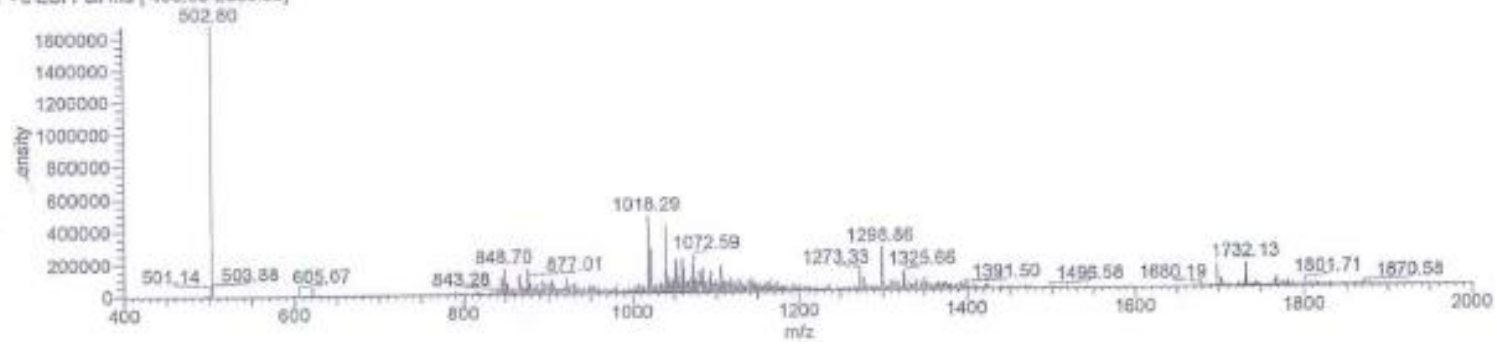


Table 3, entry 5A:

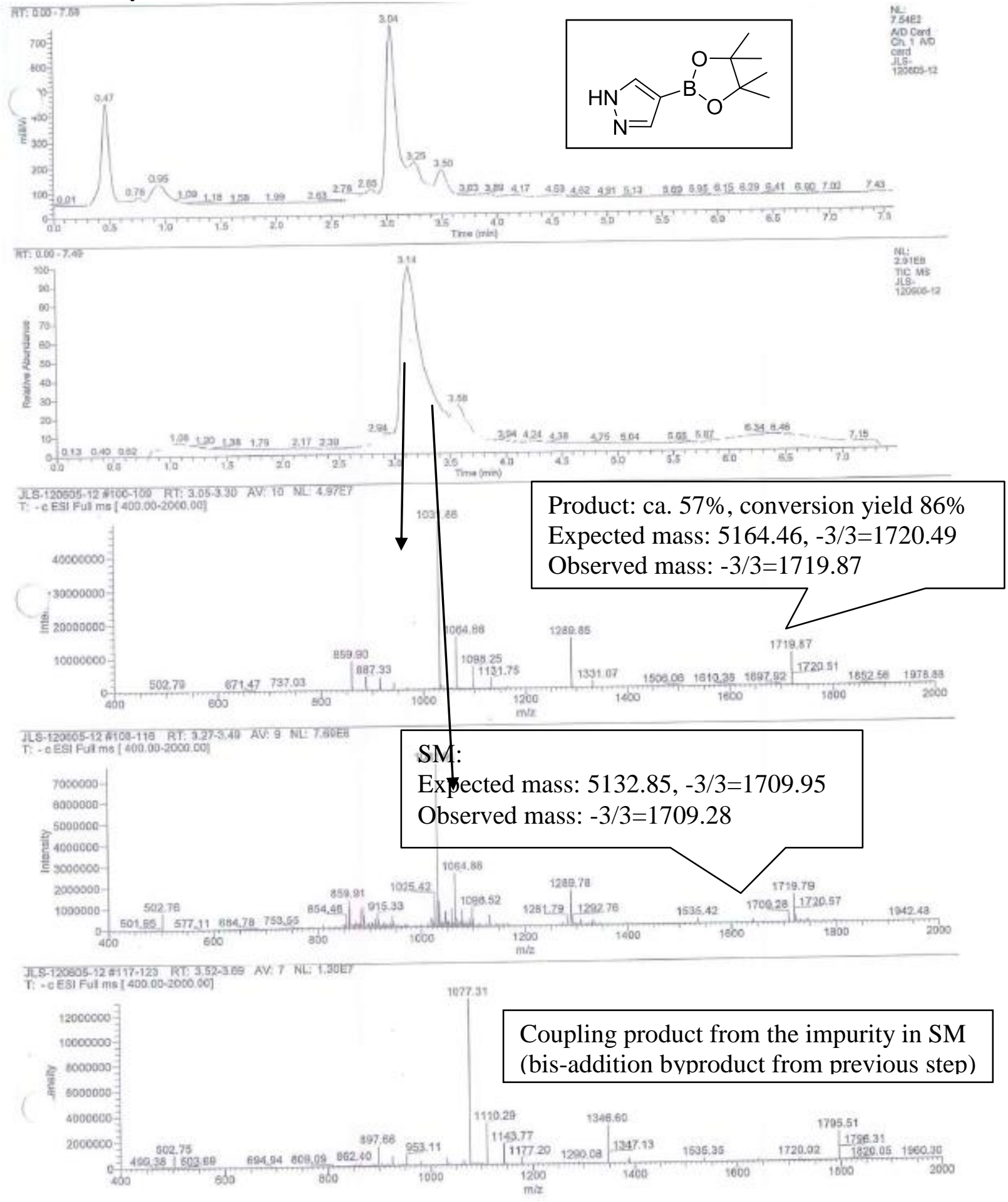


Table 3, entry 5B:

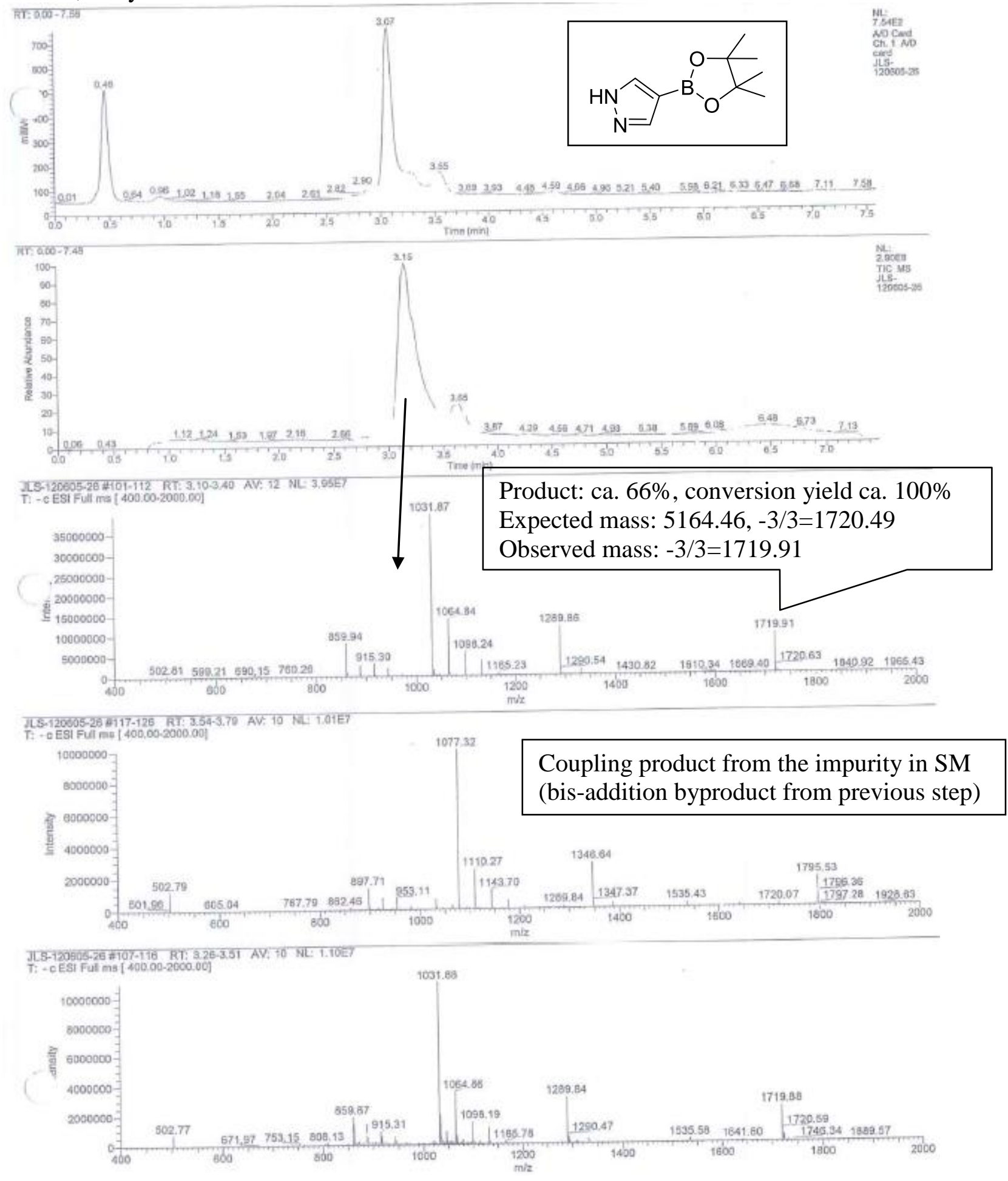


Table 3, entry 6A:

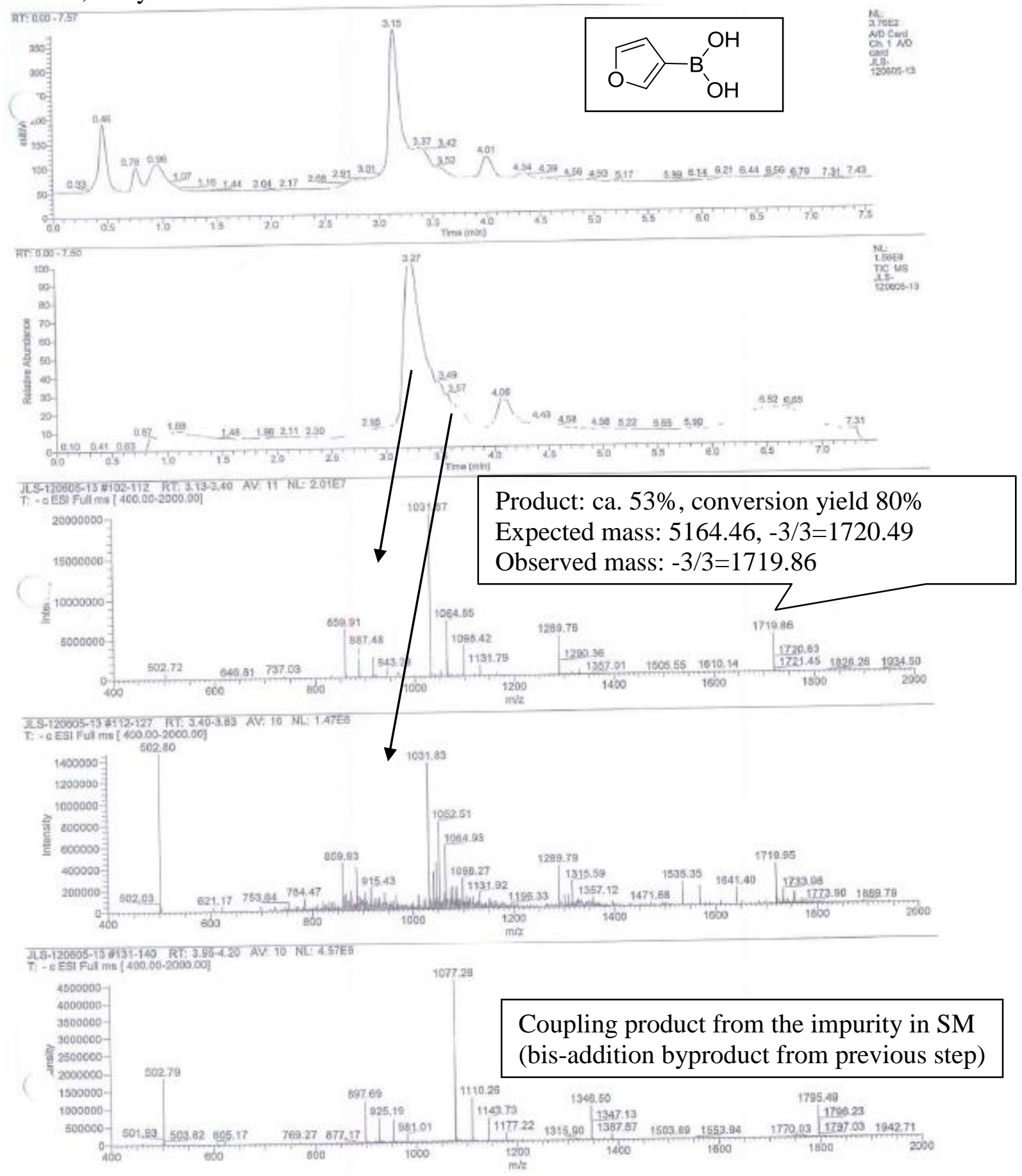


Table 3, entry 6B:
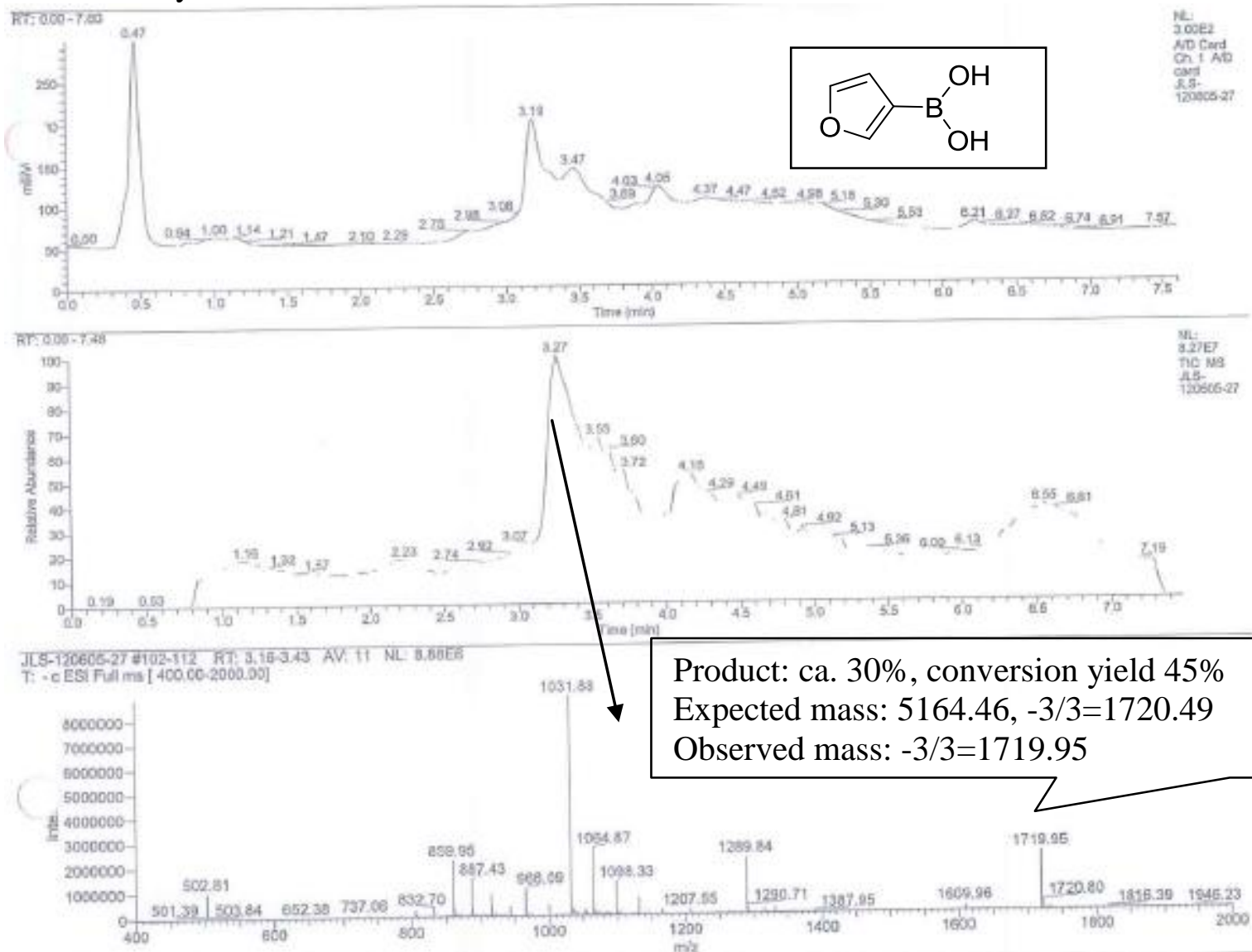

JLS. 12005

T: - CESI Ful ms ( $10000.2000,0$ 이

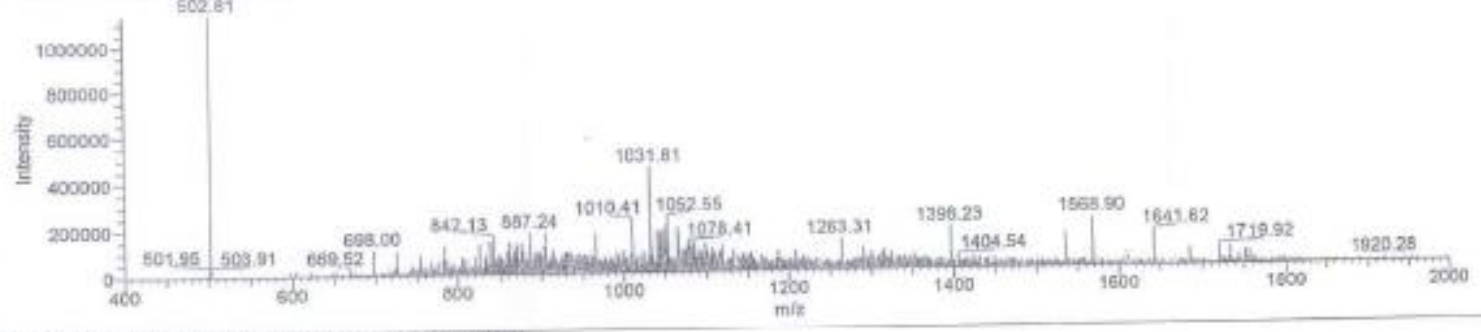

JLS-120505-27 \#133.154 RT: 4,03/4.63 AV, 22 NL: 1.53EC

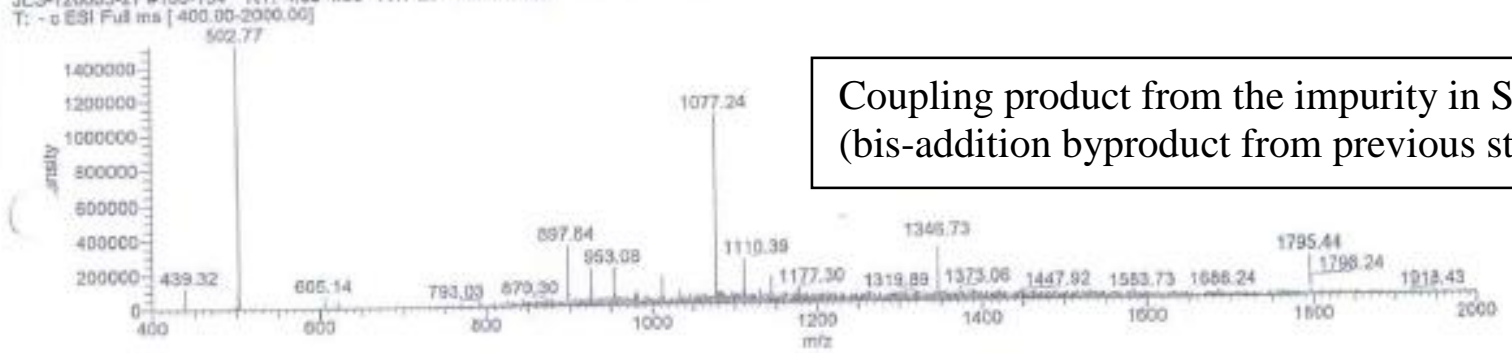


Table 3, entry 7A:

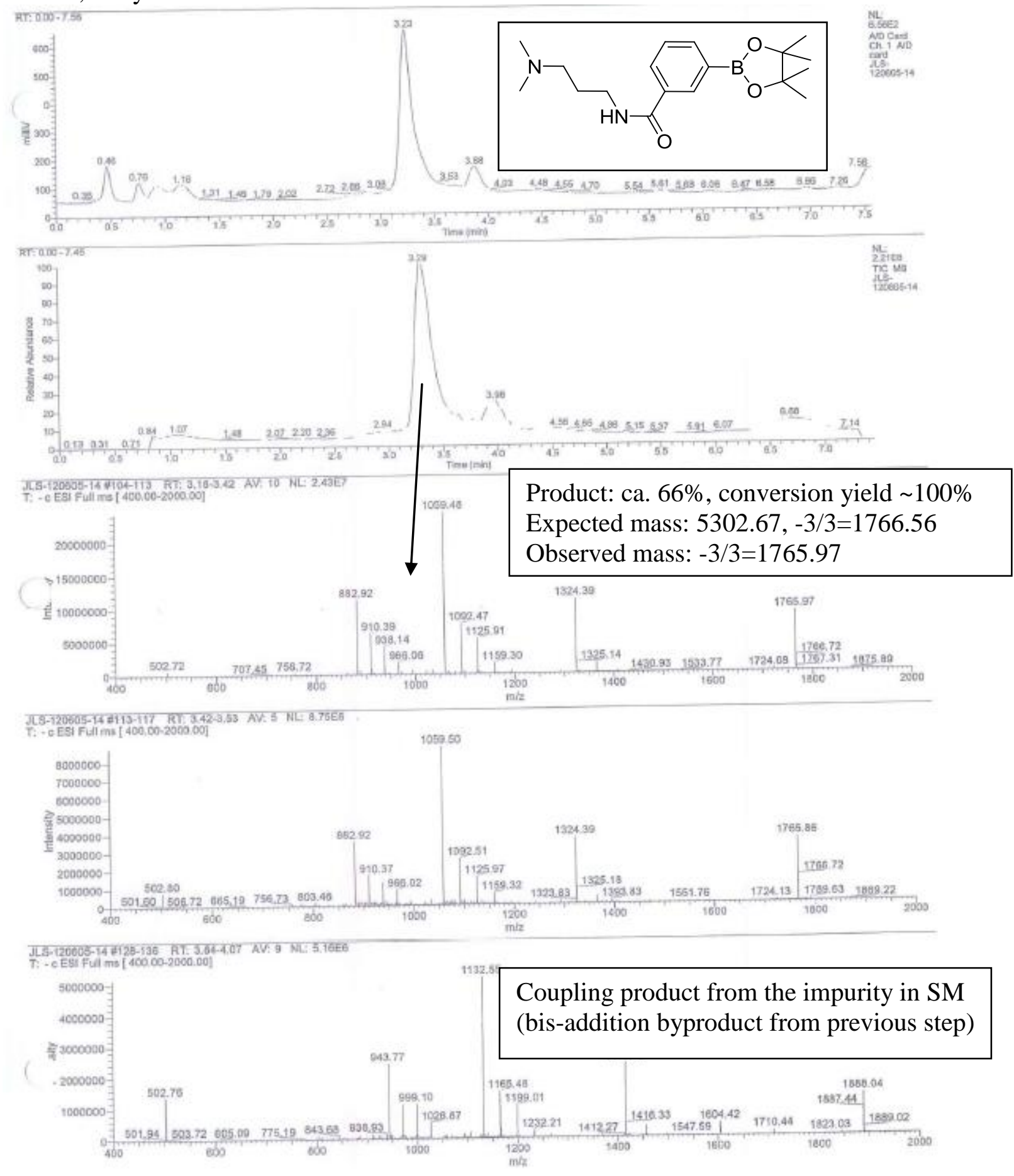


Table 3, entry 7B:
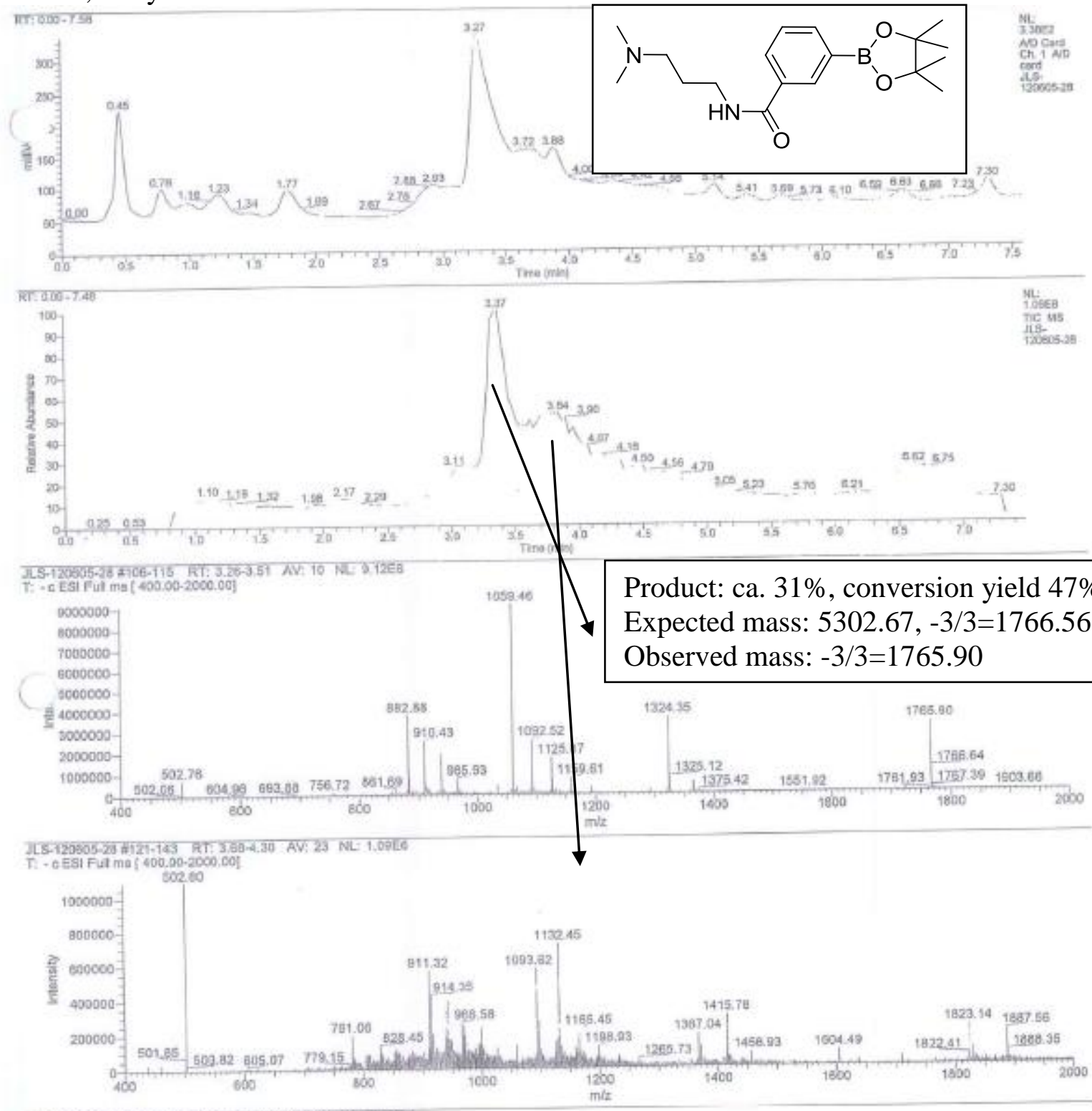

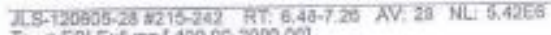

T:- e EBI Fuf ins [ $400.00-200000$ ]

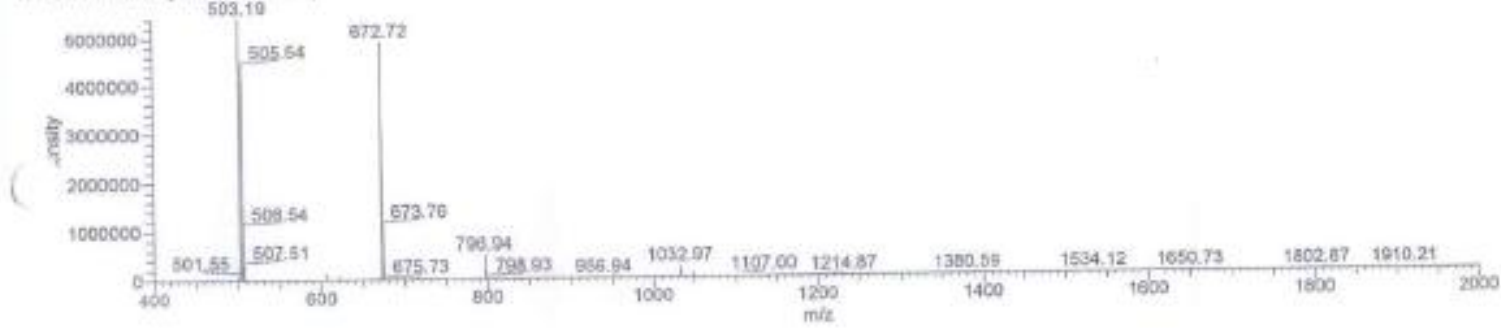


Table 3, entry 8A:
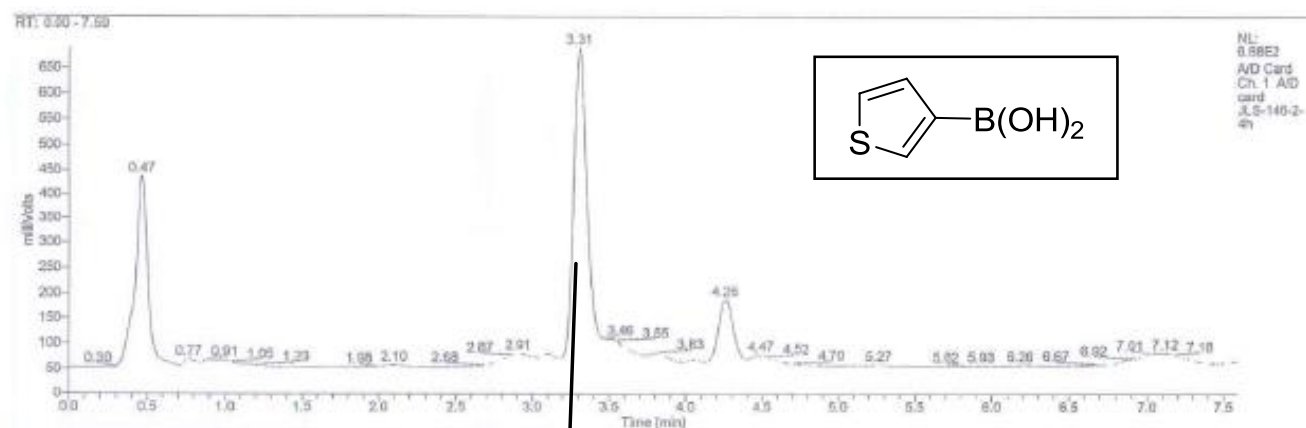

J.S-146-2-4h \#104-111 RT: $3.21-3.41$ AV: 8 NL: 3.87E T: - c ESI Full ms [ $400.00-2000.00]$
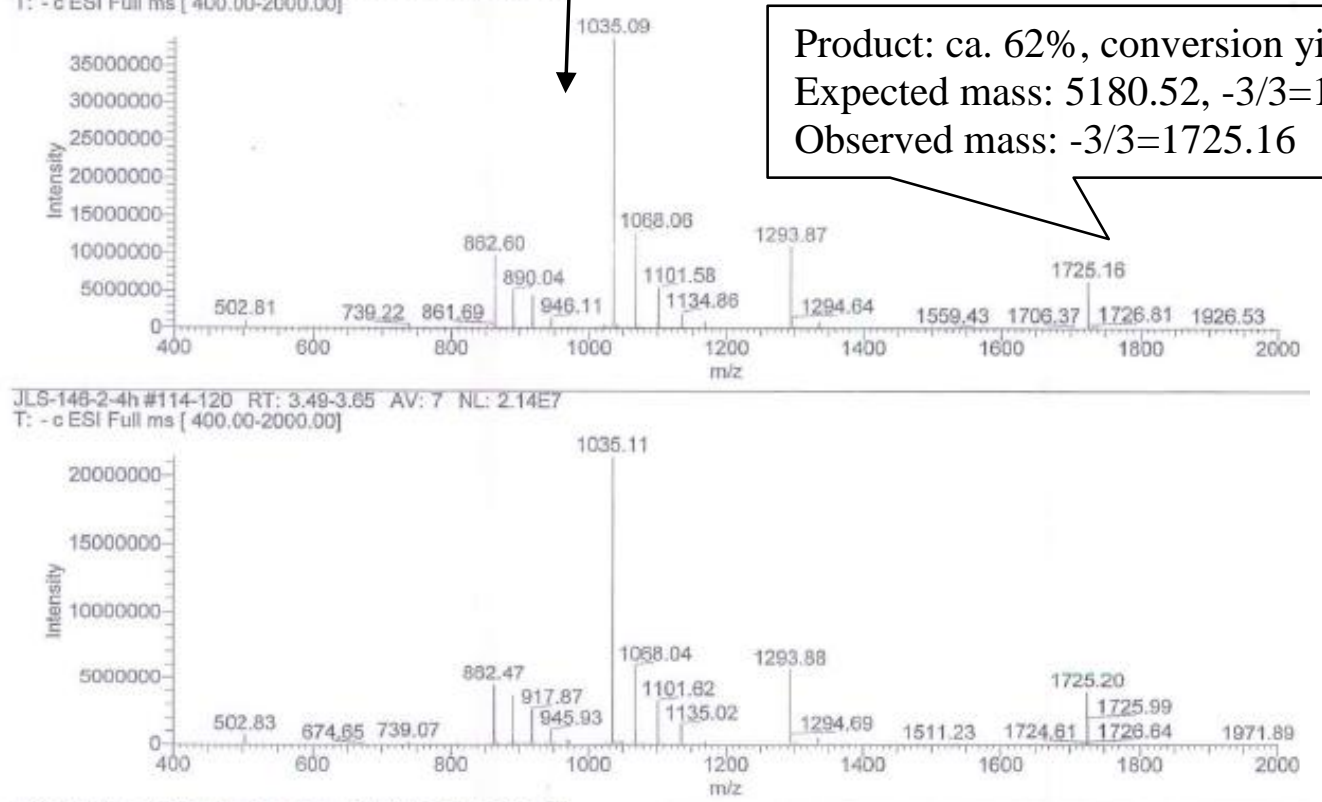

JLS-148-2-4h \#138-144 RT: 4.17-4.34 AV: 7 NL: 9.34E6

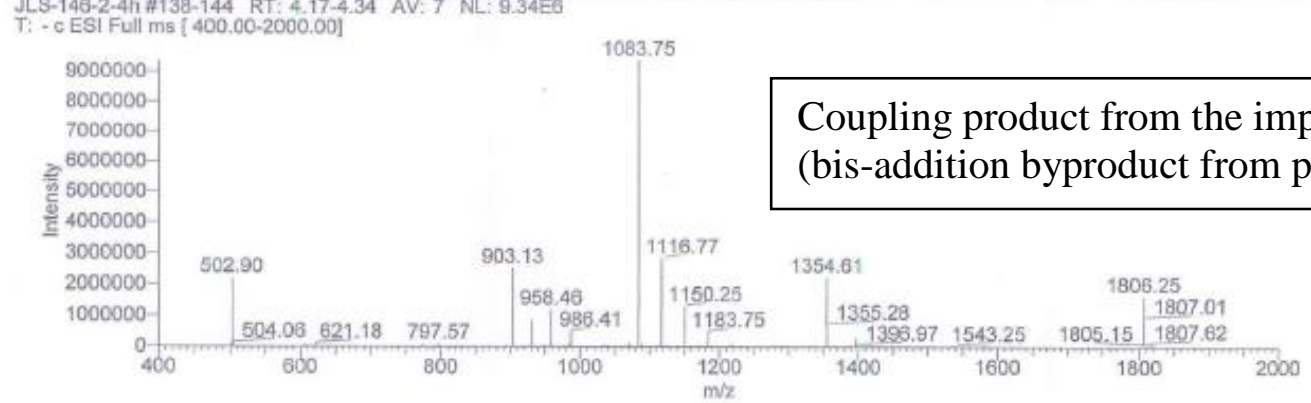


Table 3, entry 8B:

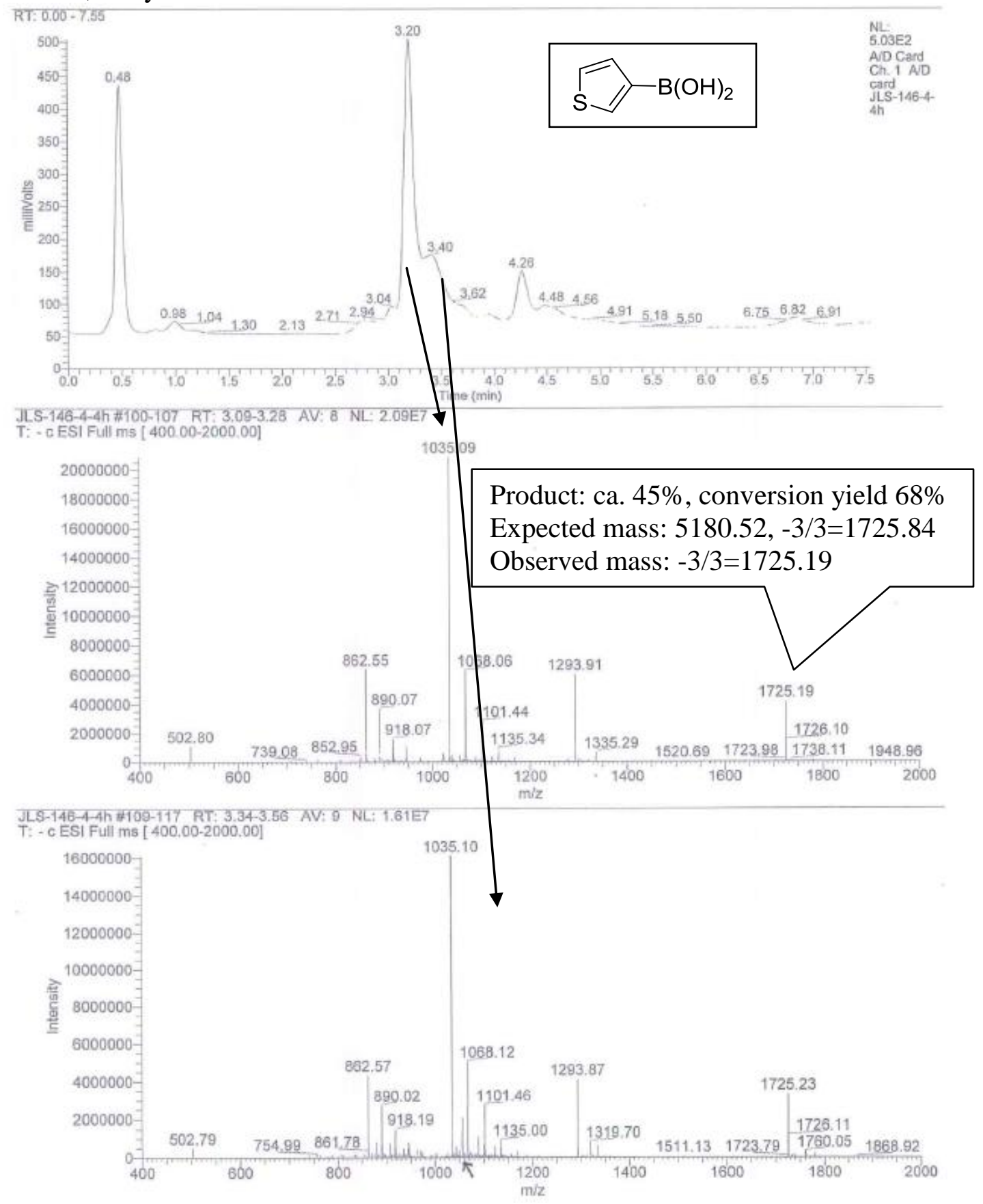




\section{Preparation of HP-5}

$100 \mu \mathrm{L}$ of 3-chlorobenzoic acid solution (200mM in DMF, $20 \mu \mathrm{mol}$ ) was mixed with $100 \mu \mathrm{L}$ of HATU solution ( $200 \mathrm{mM}$ in DMF, $20 \mu \mathrm{mol}$ ), followed by adding $50 \mu \mathrm{L}$ of DIEA solution (400 $\mathrm{mM}$ in DMF, $20 \mu \mathrm{mol})$. The solution was mixed and added to $1 \mathrm{~mL}$ of HP solution in $\mathrm{pH} 9.4$ borate buffer $(250 \mathrm{mM})(1 \mathrm{mM}, 1 \mu \mathrm{mol})$. The reaction was monitored with LCMS, which showed the completion of the acylation within 5 mins at RT. The reaction was precipitated by adding $10 \% 5 \mathrm{~N} \mathrm{NaCl}$ water solution and 2.5 times volume of absolute EtOH. Redissolve the pellet with $1 \mathrm{~mL}$ of water to make $\sim 1 \mathrm{mM}$ concentration of HP-5 solution. It would be used directly with Suzuki coupling without further purification.

\section{Preparation of HP-6}

$100 \mu \mathrm{L}$ of 4-chlorobenzoic acid solution (200mM in DMF, $20 \mu \mathrm{mol})$ was mixed with $100 \mu \mathrm{L}$ of HATU solution ( $200 \mathrm{mM}$ in DMF, $20 \mu \mathrm{mol}$ ), followed by adding $50 \mu \mathrm{L}$ of DIEA solution (400 $\mathrm{mM}$ in DMF, $20 \mu \mathrm{mol})$. The solution was mixed and added to $1 \mathrm{~mL}$ of HP solution in $\mathrm{pH} 9.4$ borate buffer $(250 \mathrm{mM})(1 \mathrm{mM}, 1 \mu \mathrm{mol})$. The reaction was monitored with LCMS, which showed the completion of the acylation within 5 mins at RT. The reaction was precipitated by adding $10 \% 5 \mathrm{~N} \mathrm{NaCl}$ water solution and 2.5 times volume of absolute EtOH. Redissolve the pellet with $1 \mathrm{~mL}$ of water to make $\sim 1 \mathrm{mM}$ concentration of HP-6 solution. It would be used directly with Suzuki coupling without further purification.

General procedure for the coupling of HP-5,6 with boronates in Table 4 using POPd/ligand $\mathbf{1}$.

A $1 \mathrm{mM}$ solution of HP-5 or $\mathbf{- 6}$ in water $(20 \mathrm{nmol}, 20 \mu \mathrm{L})$ was added 40 equivalents of boronate $(1 \mu \mathrm{L}, 400 \mathrm{mM}$ in DMA $)$ and 80 equivalents of $\mathrm{KOH}(1 \mu \mathrm{L}, 800 \mathrm{mM}$ in water), followed by 1 equivalent of POPd/Ligand $\mathbf{1}(1 / 2)$ solution, which was mixed by 2 equivalents of ligand $\mathbf{1}$ (1 $\mu \mathrm{L}, 40 \mathrm{mM}$ in water) and 1 equivalent of POPd $(1 \mu \mathrm{L}, 20 \mathrm{mM}$ in DMA). The reaction was allowed to proceed at $80^{\circ} \mathrm{C}$ for 3 hours. 
Table 4, entry 1A:

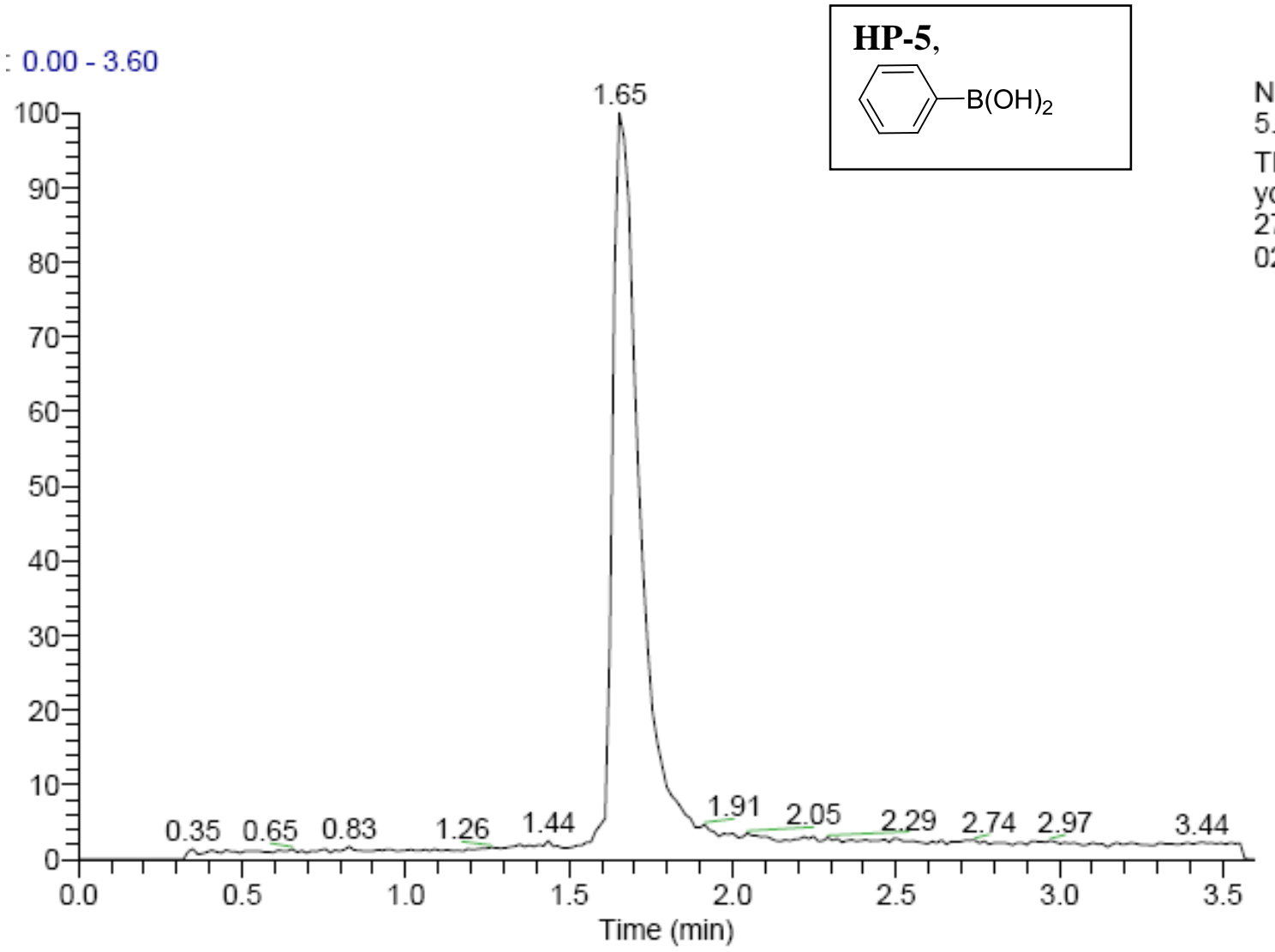

N15345-27-80C3h-02 \#110-130 RT: 1.58-1.87 AV: 21 NL: 7.24E2

ITMS - c ESI Full ms [600.00-2000.00]

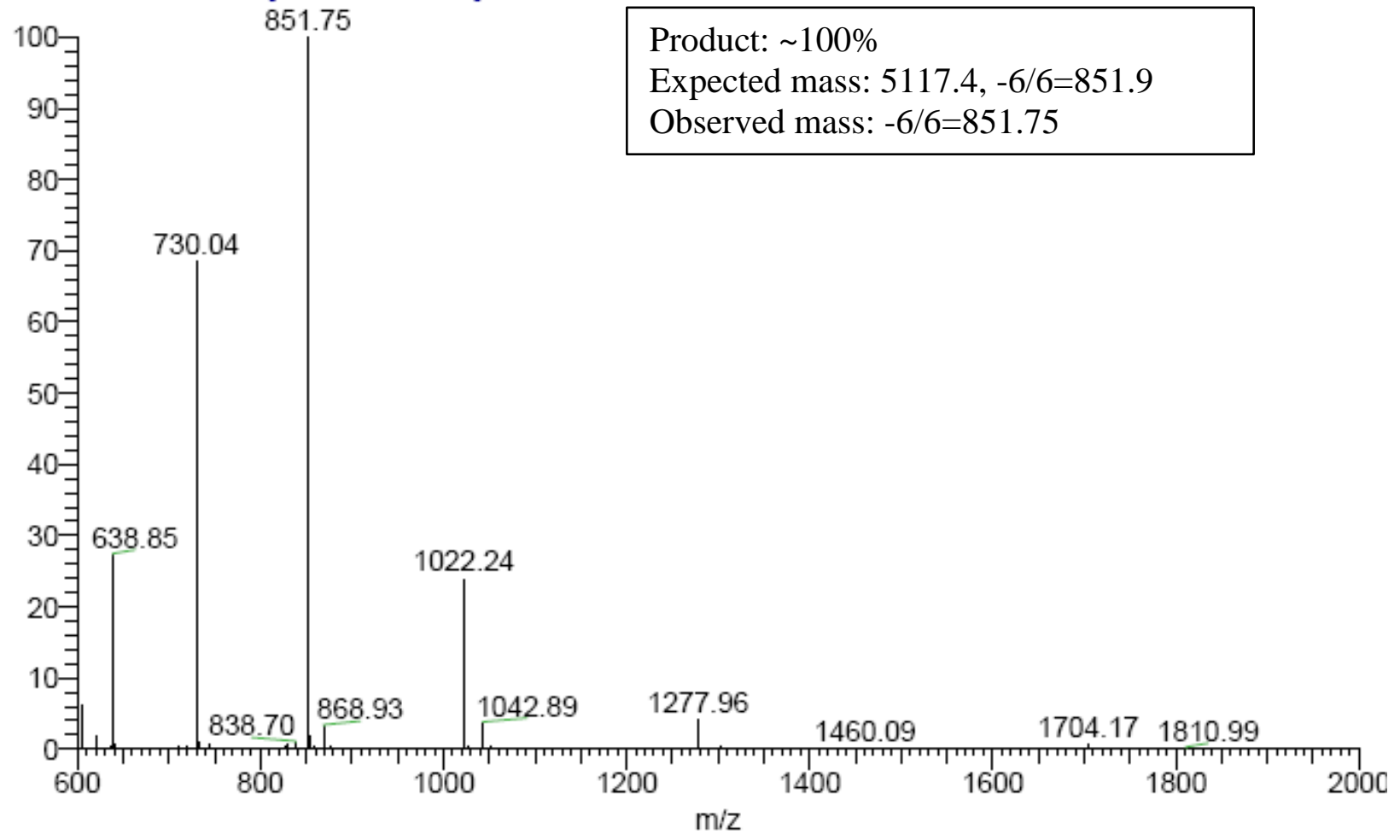


Table 4, entry $2 \mathrm{~A}$

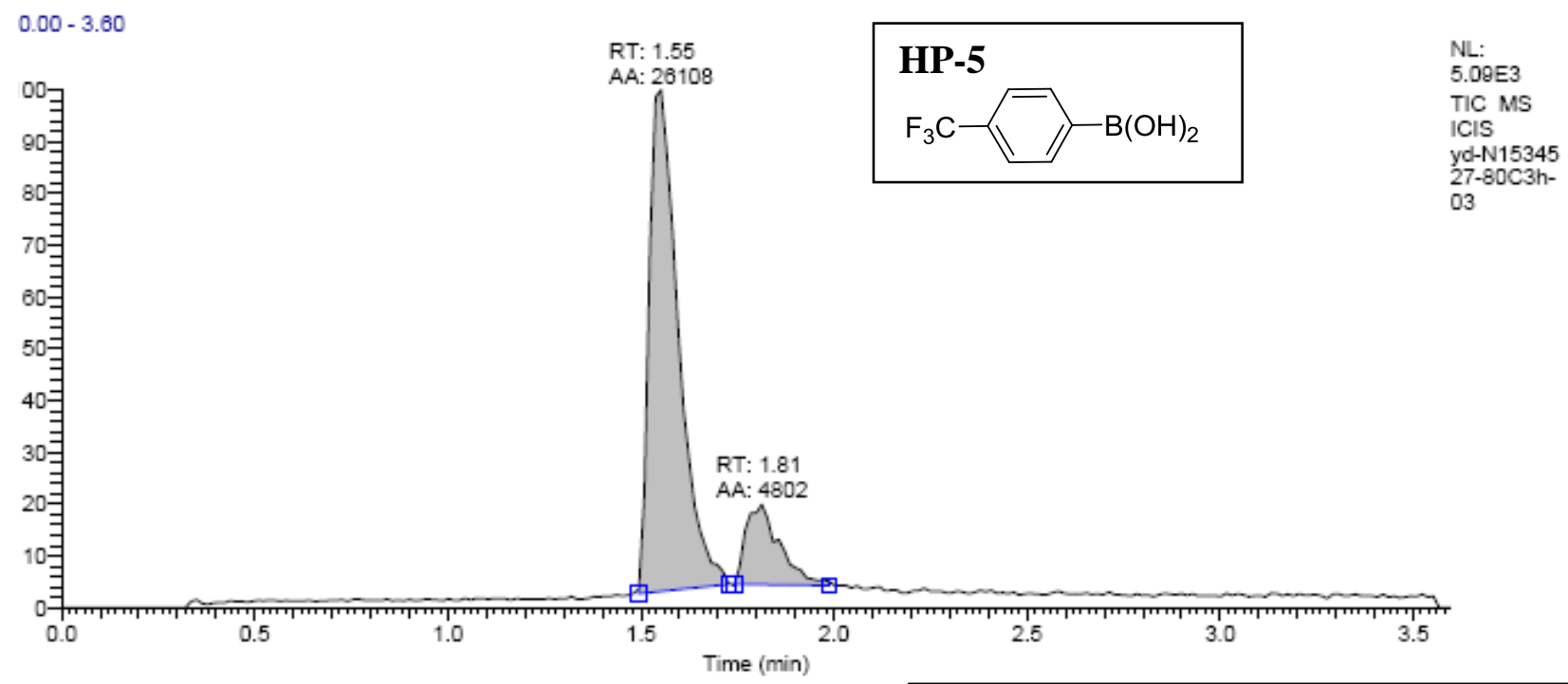

15345-27-80C3h-03\#104-120 RT: $1.49-1.73$ AV: 17 NL: $7.58 E 2$ MS - c ESI Full ms [800.00-2000.00]

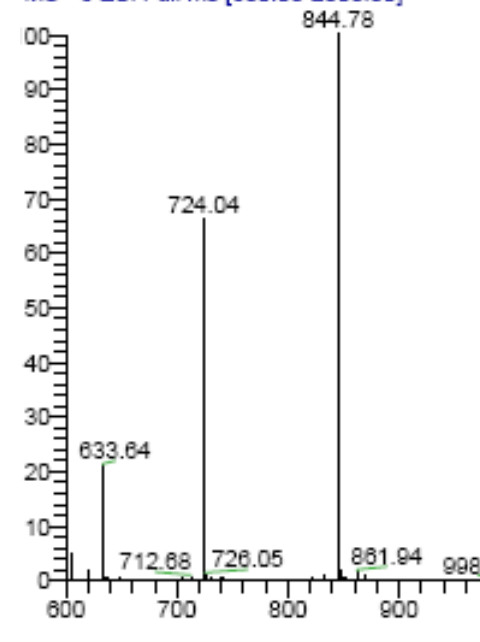

SM: $85 \%$

Expected mass: $5075.75,-6 / 6=844.96$

Observed mass: $-6 / 6=844.78$

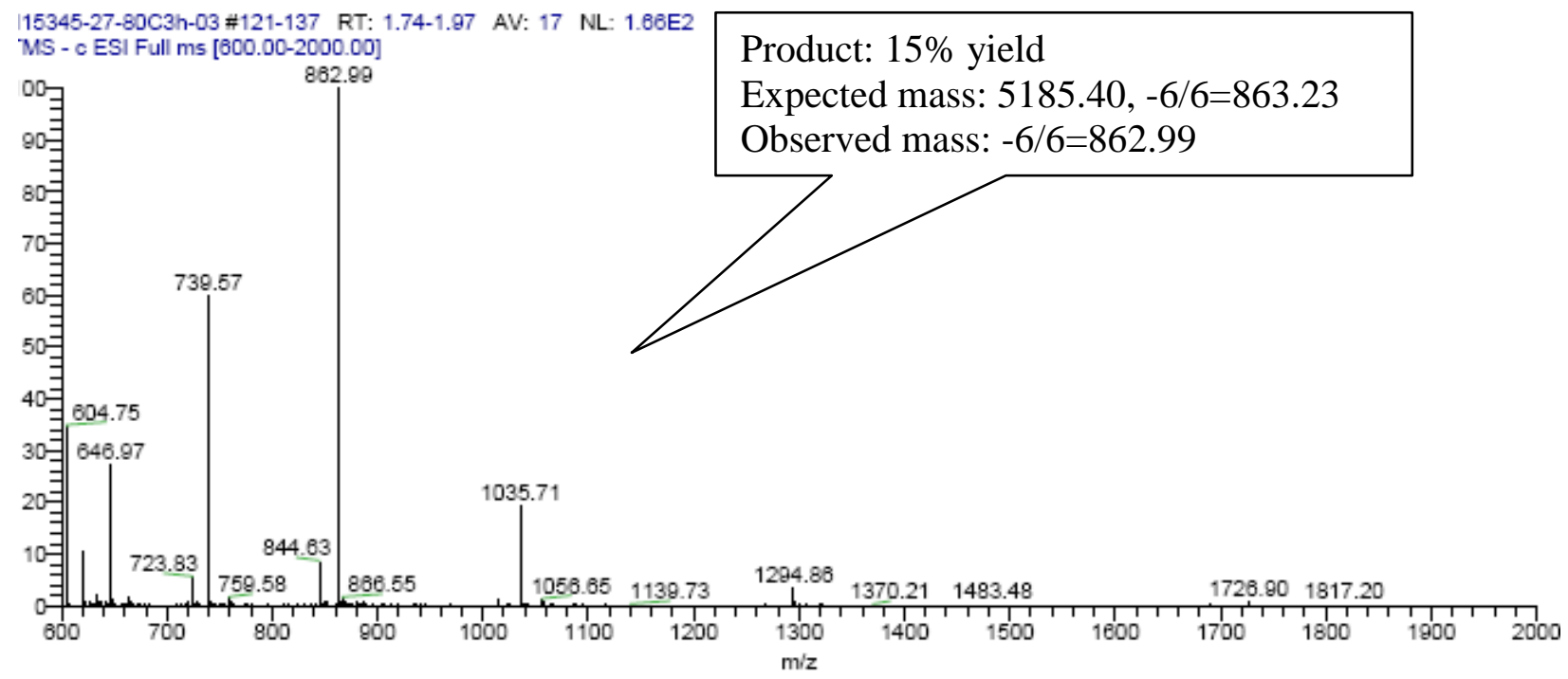


Table 4, entry 3A:

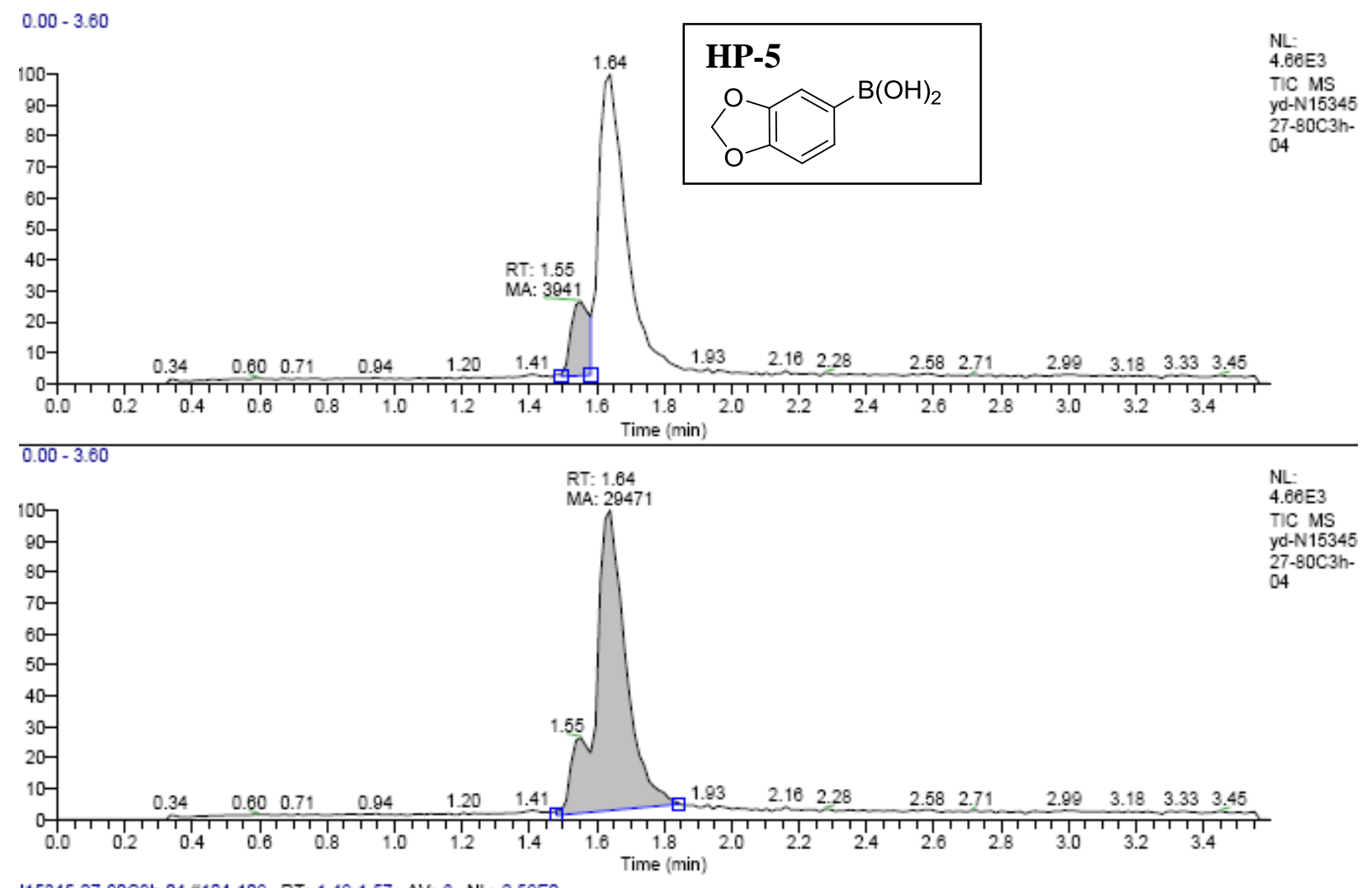

115345-27-80C3h-04 \#104-109 RT: $1.48-1.57$ AV: 6 NL: $2.59 E 2$ TMS - c ESI Full ms [600.00-2000.00]

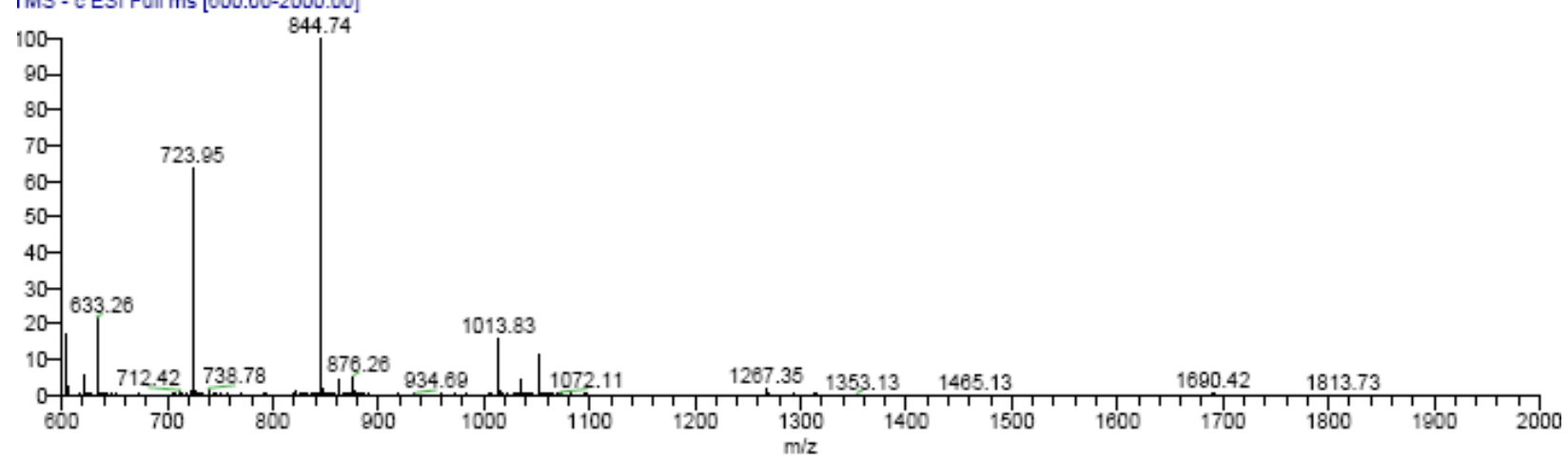

115345-27-80C3h-04 \#111-126 RT: $1.60-1.81$ AV: 16 NL: $6.77 E 2$ [MS - c ESI Full ms [600.00-2000.00]
859.10

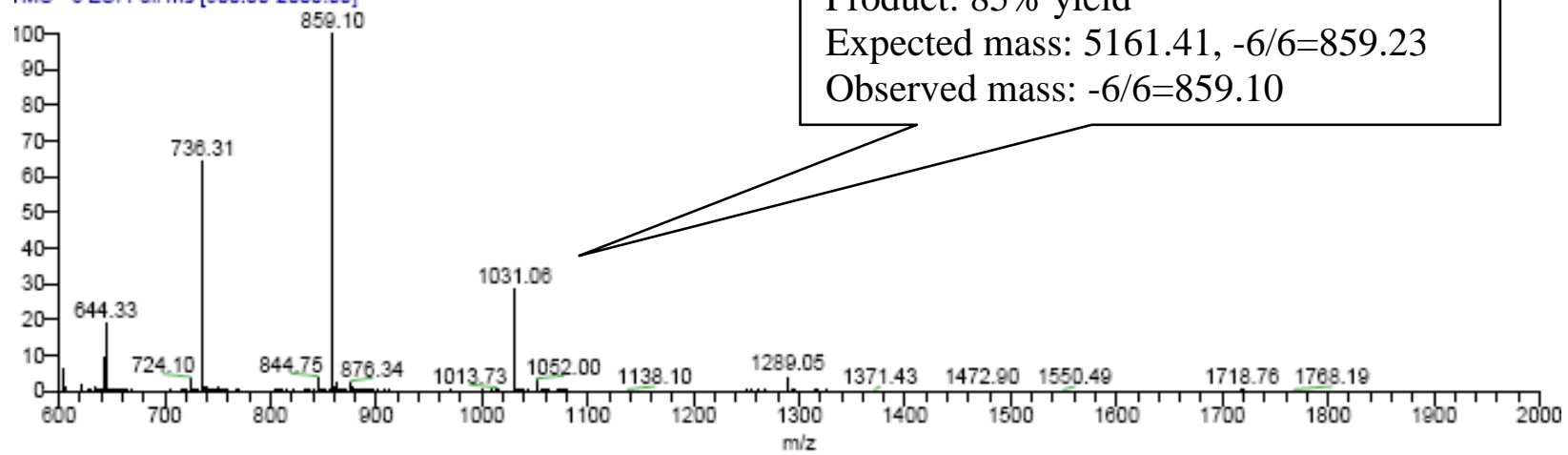


Table 4, entry 4A:

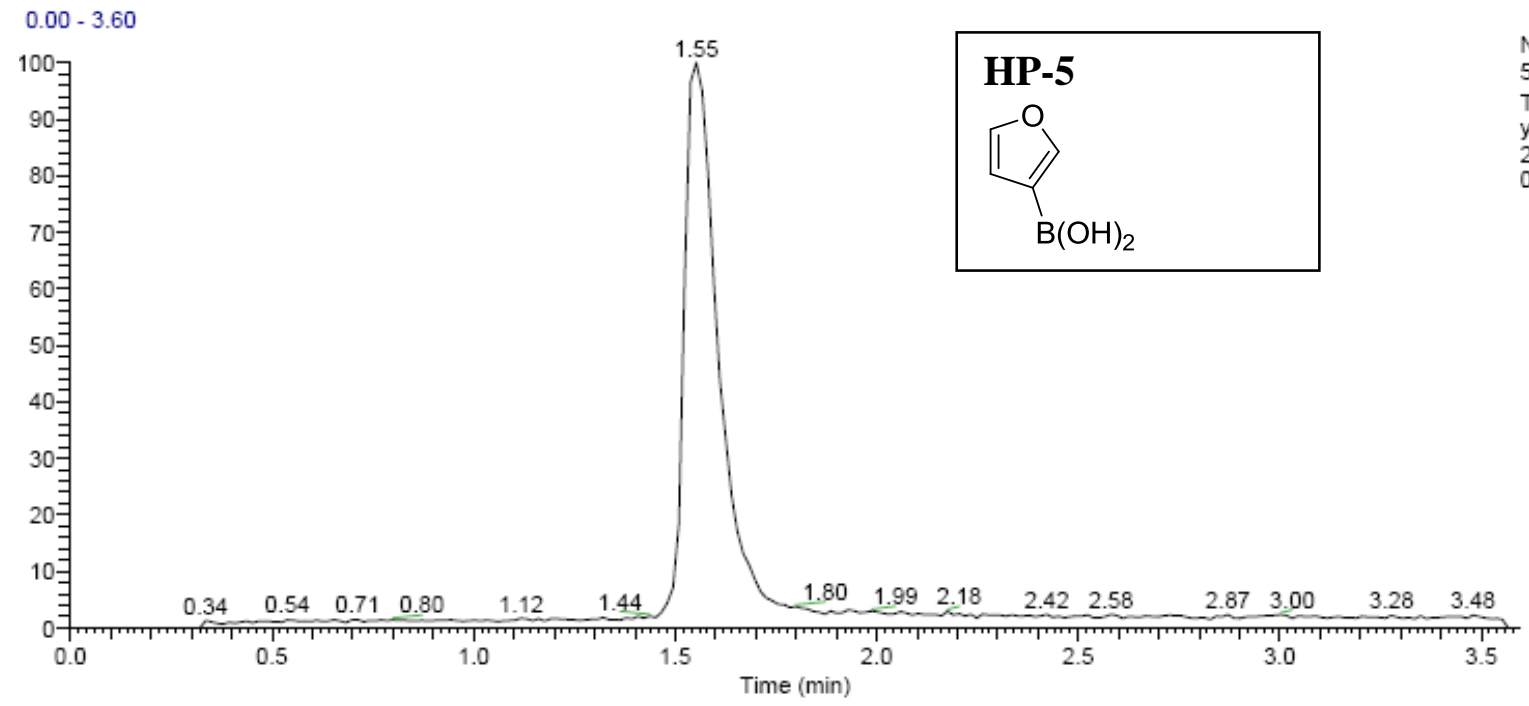

J15345-27-80C3h-05\#101-127 RT: 1.45-1.83 AV: 27 NL: $4.71 E 2$

TMS - c ESI Full ms [600.00-2000.00]

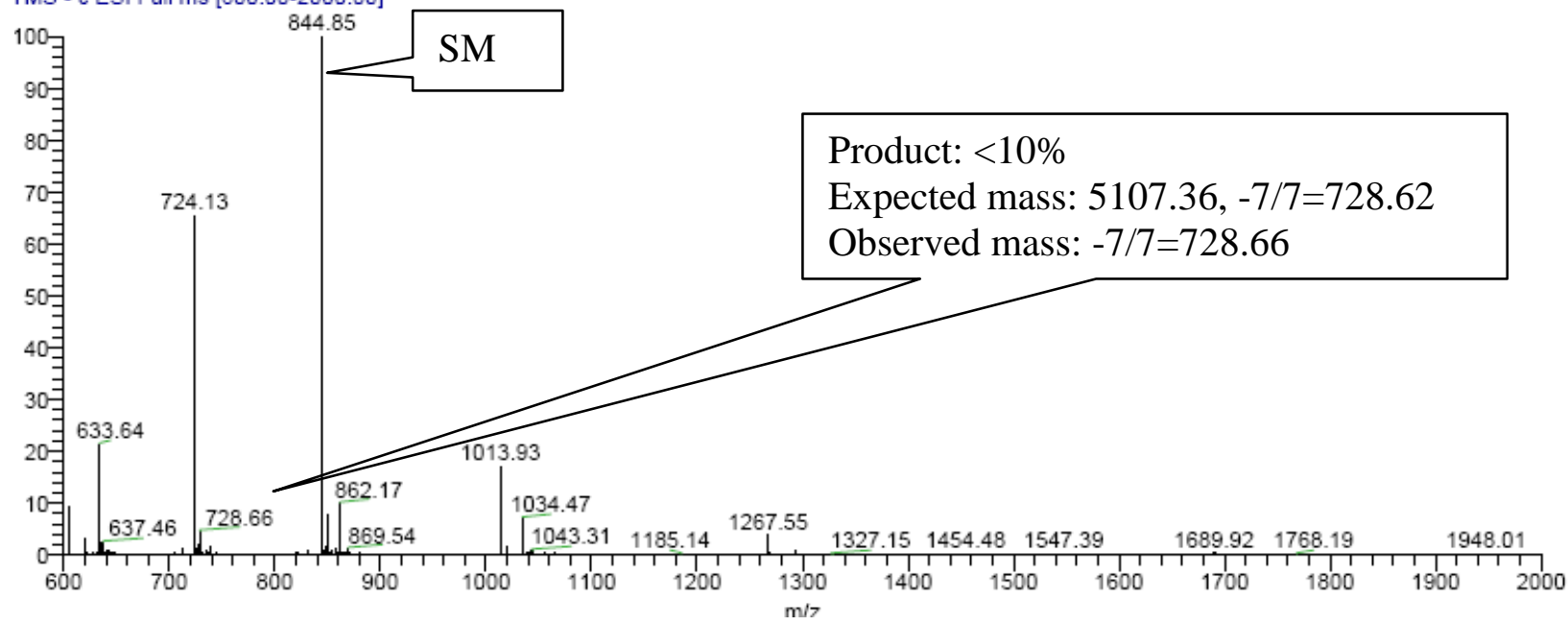


Table 4, entry 5A:

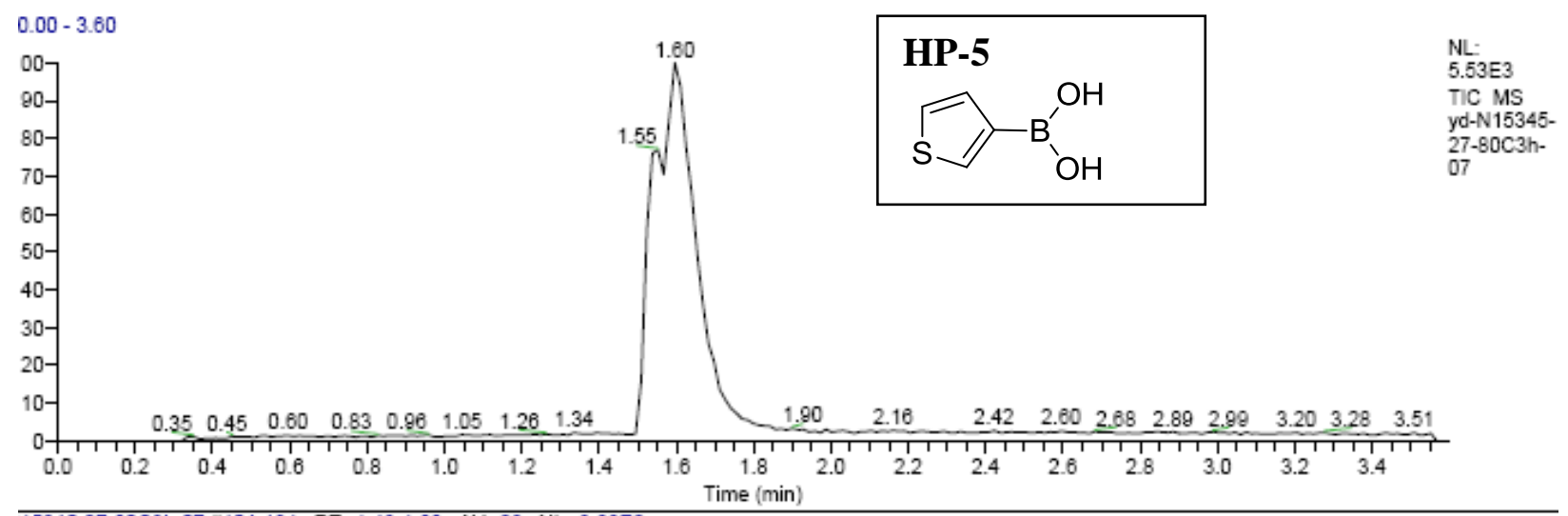

15345-27-80C3h-07 $=104-131$ RT: $1.49-1.89$ AV: 28 NL: $3.88 E 2$

MS - c ESI Full ms [000.00-2000.00]

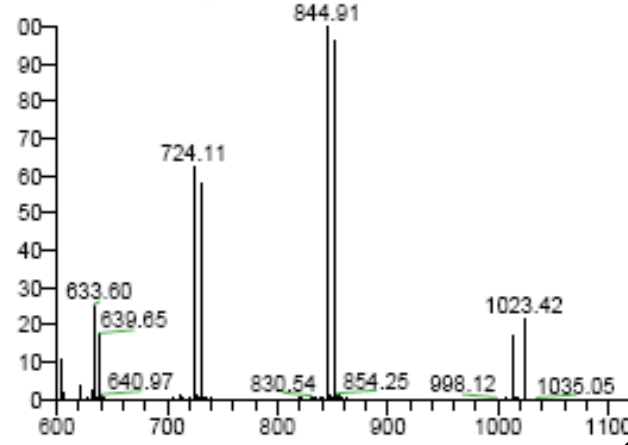

Product: $\sim 60 \%$ yield

Expected mass: $5123.43,-6 / 6=852.91$

Observed mass: $-6 / 6=852.72$

15345-27-80C3h-07 \#104-131 RT: 1.49-1.89 AV: 28

MS - c ESI Full ms [000.00-2000.00]
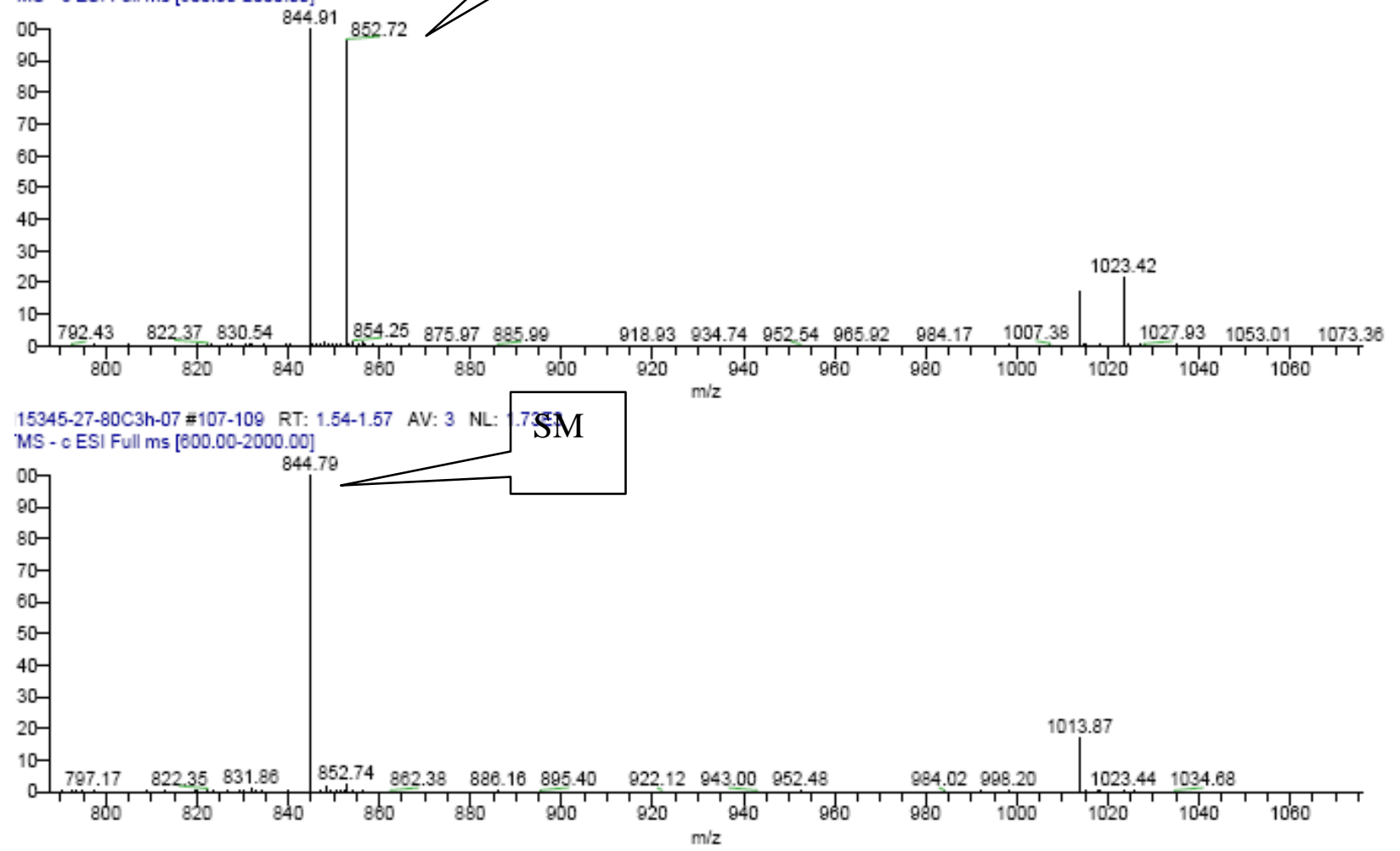
Table 4, entry 6A:

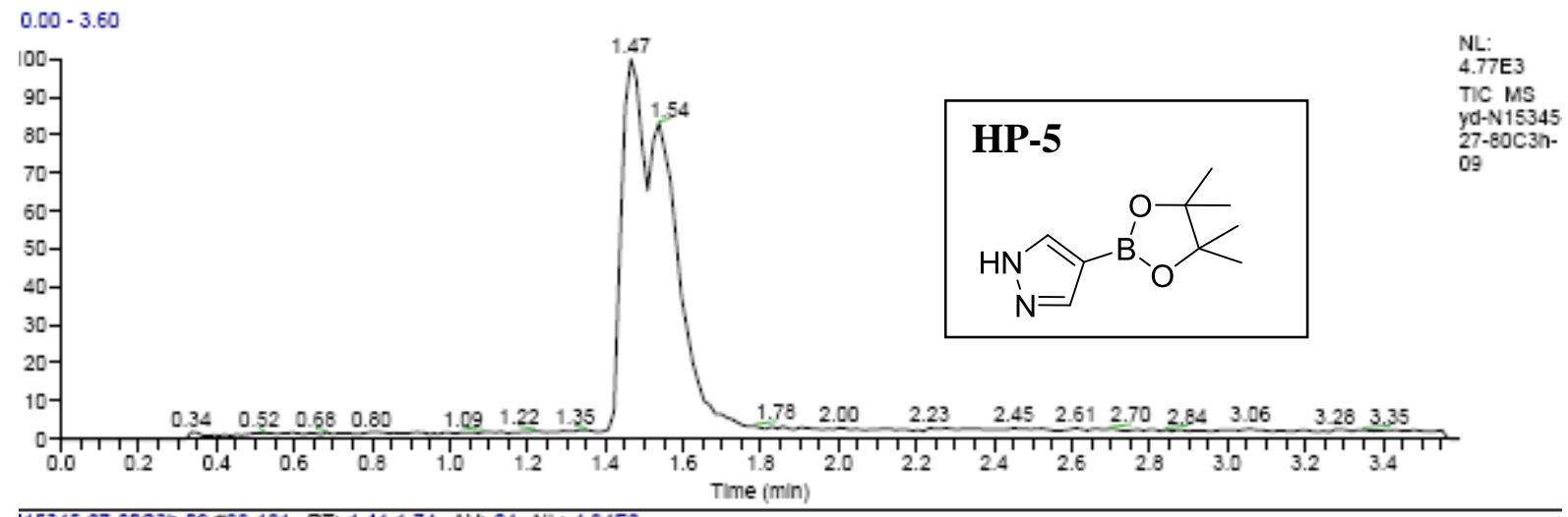

15345-27-80C3h-09 $798-121$ RT: $1.41-1.74$ AV: 24 NL: 4.94E2

MS - c ESI Full ms [600.00-2000.00]

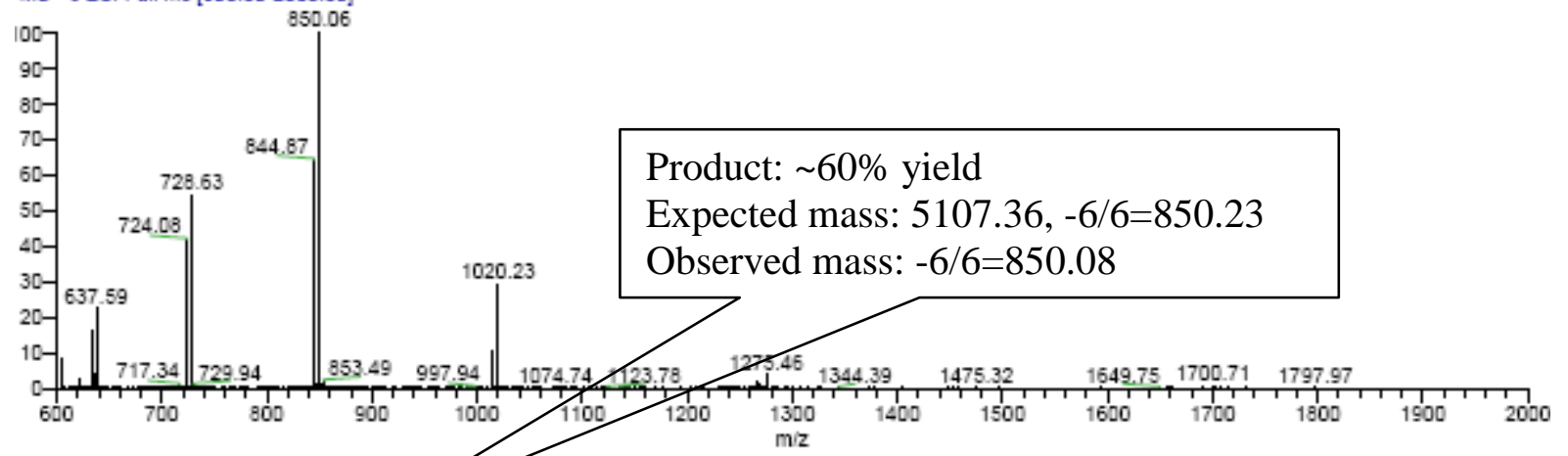

115345-27-80C3h-09 \#101-103 RT: 1.45-1.48 AV NL: $1.88 E 3$

MS - c ESI Full m5 [600.00-2000.00]

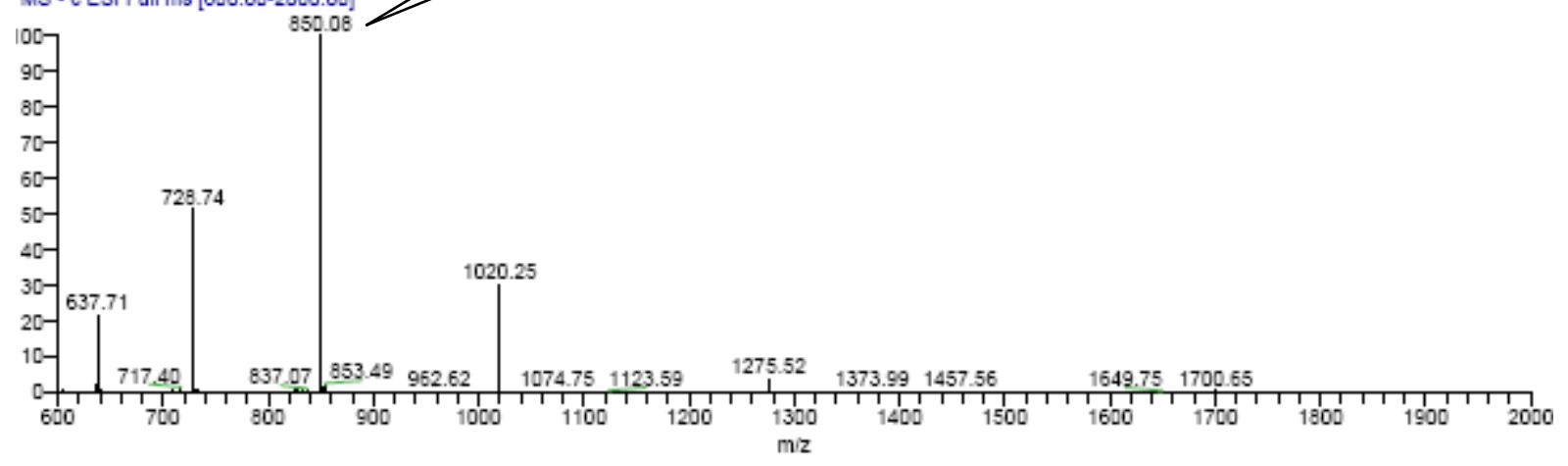

|15345-27-80C3h-09 \#106-108 RT: 1.52-1.55 AV: 3 NL: $1.09 E 3$

MS - c ESI Full m5 [600.00-2000.00]

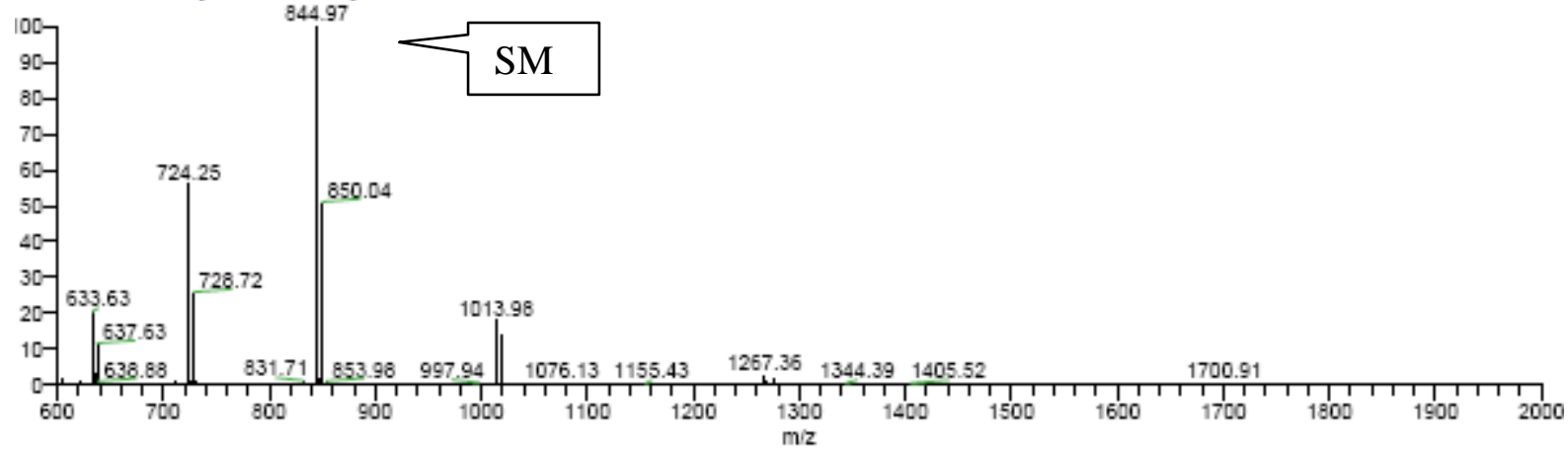


Table 4, entry 7A:

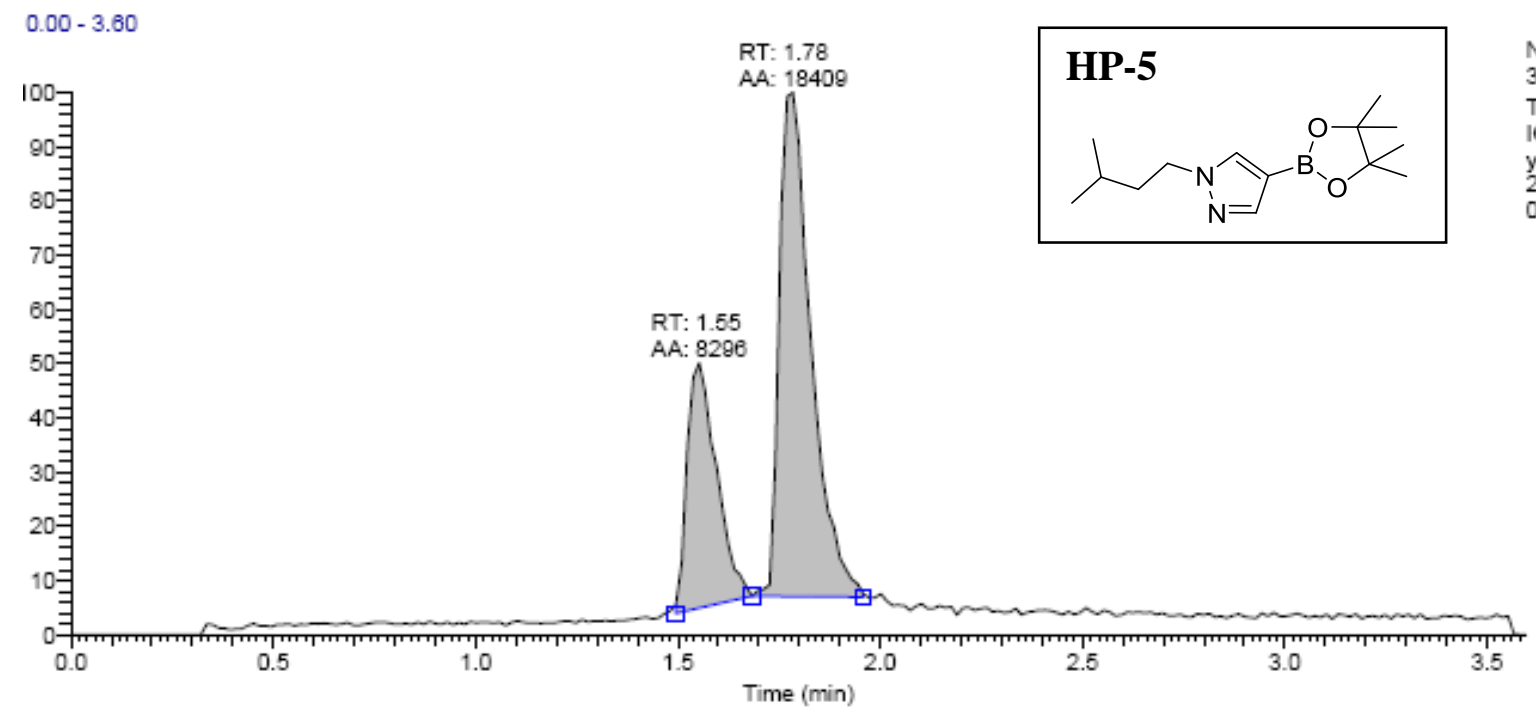

|15345-27-80C3h-08 \#103-117 RT: $1.48-1.68$ AV: 15 NL: $2.52 \mathrm{E} 2$

TMS - c ESI Full ms [600.00-2000.00]

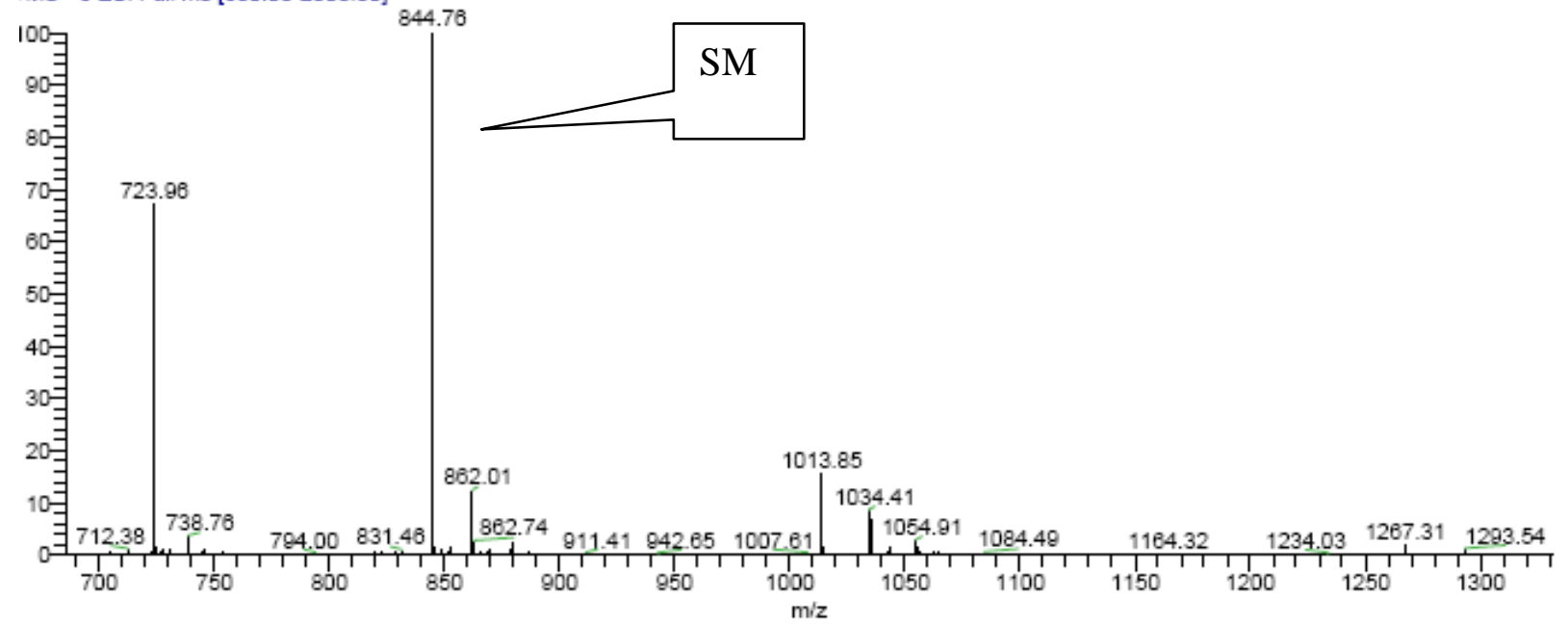

[15345-27-80C3h-08 \#119-136 RT: $1.71-1.96$ AV: 18 NL: $5.35 E 2$ TMS - c ESI Full ms [600.00-2000.00]

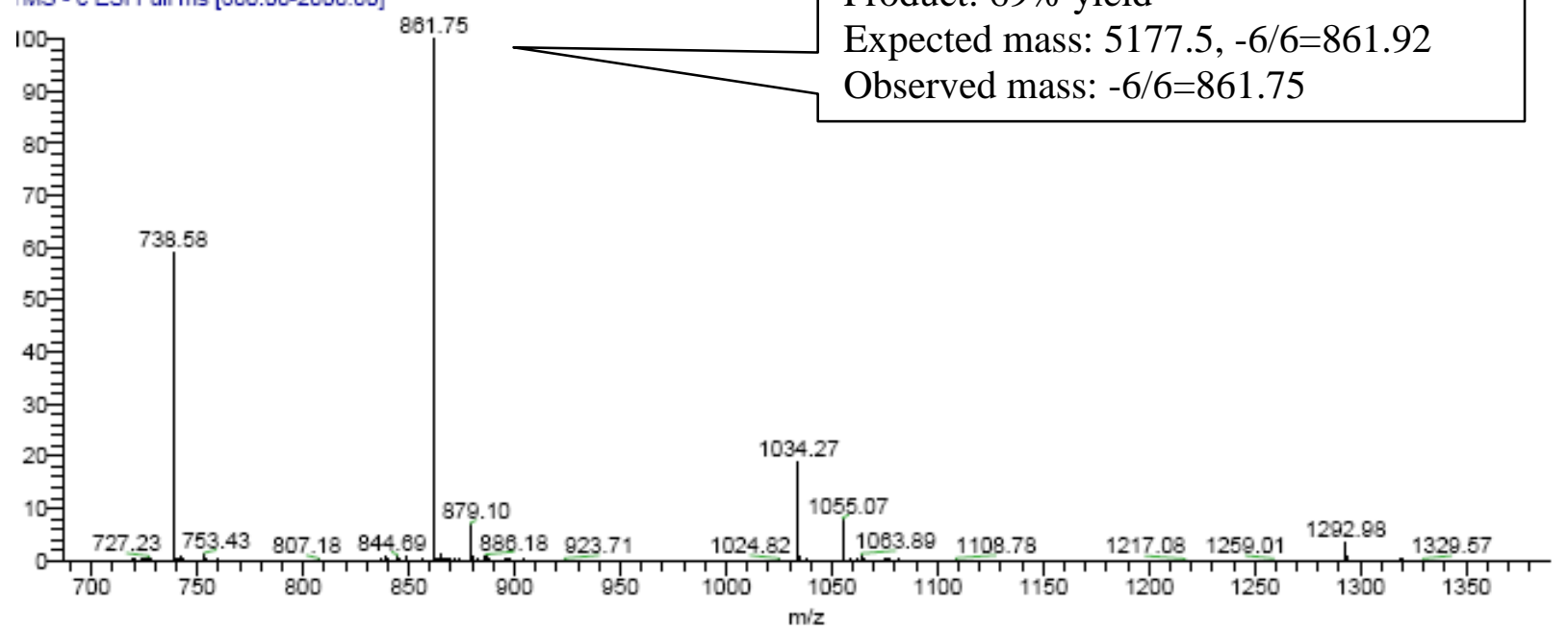


Table 4, entry 8A:

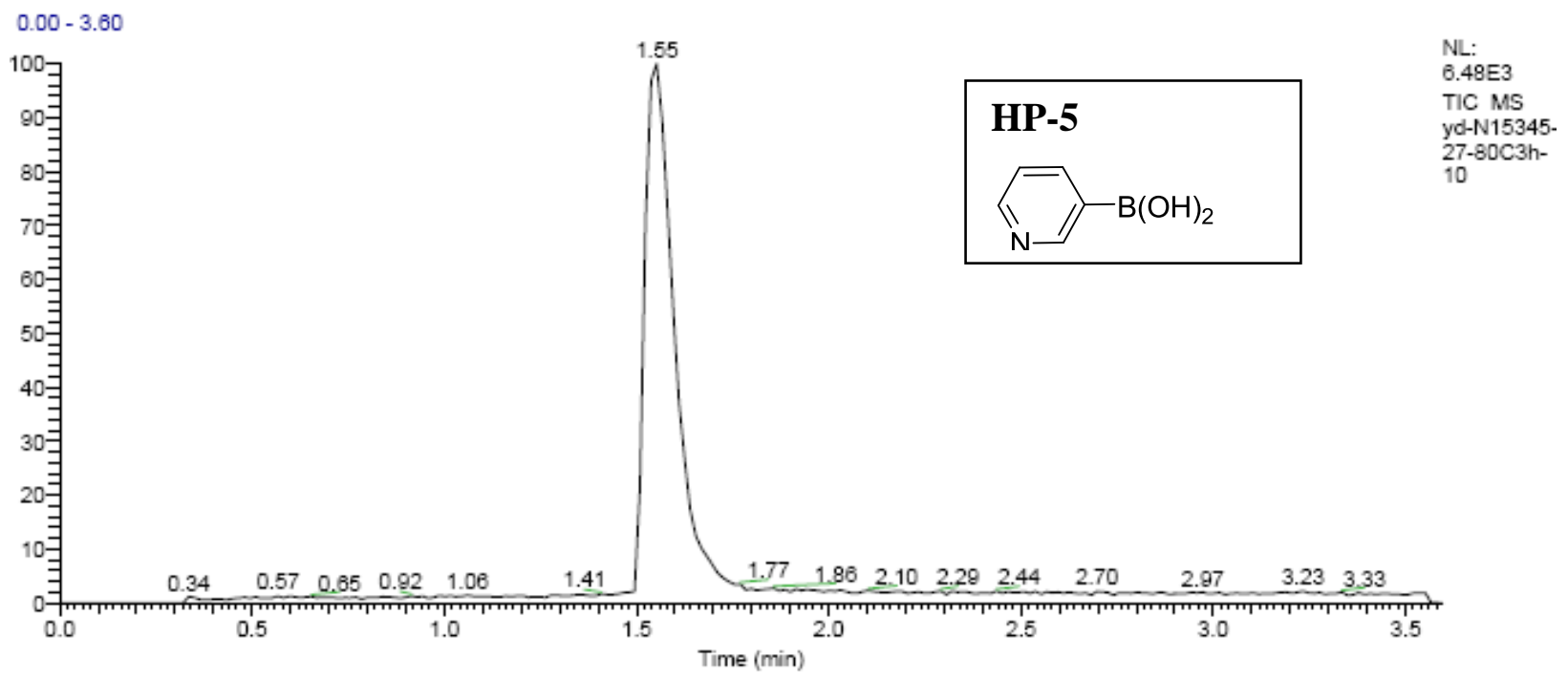

ง15345-27-80C3h-10 \#103-125 RT: $1.48-1.80$ AV: 23 NL: 7.47 E2

TMS - c ESI Full ms [600.00-2000.00]

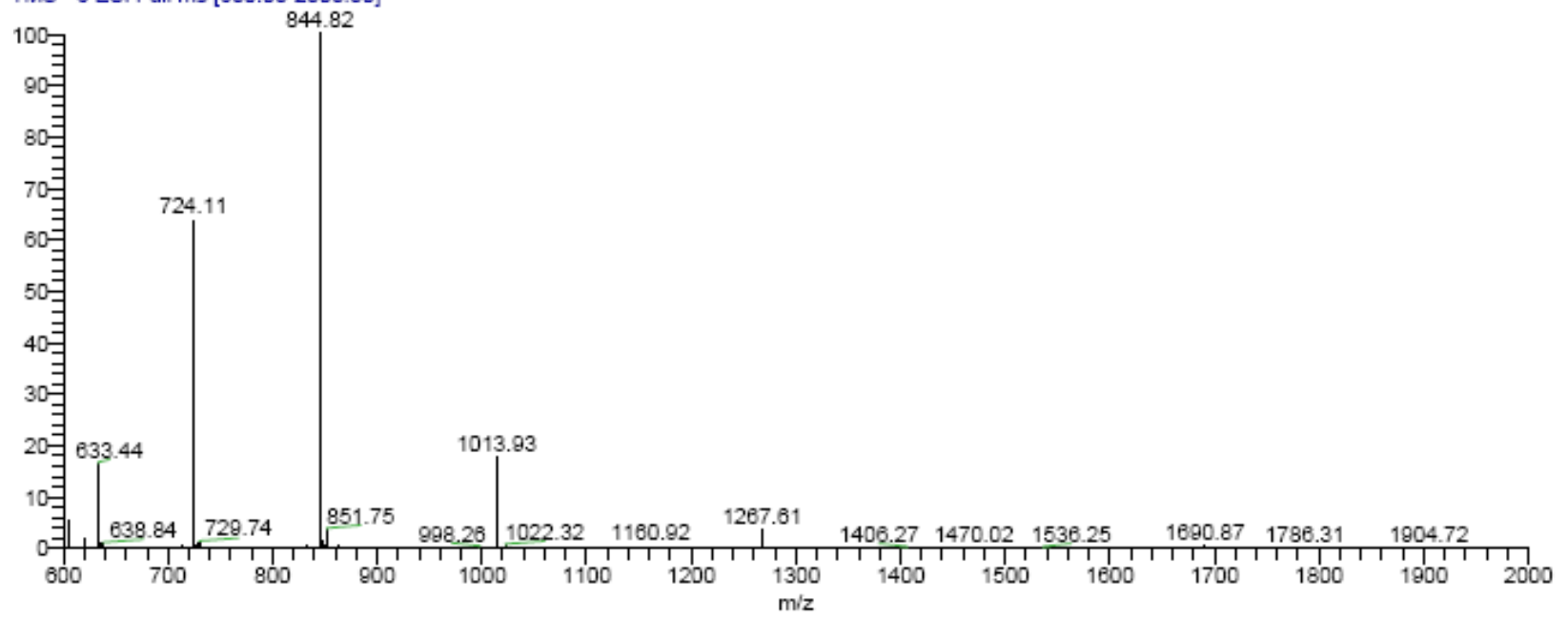

N15345-27-80C3h-10 \#103-125 RT: $1.48-1.80$ AV: 23 NL- 7.47 E2 TMS - c ESI Full ms [600.00-2000.00]

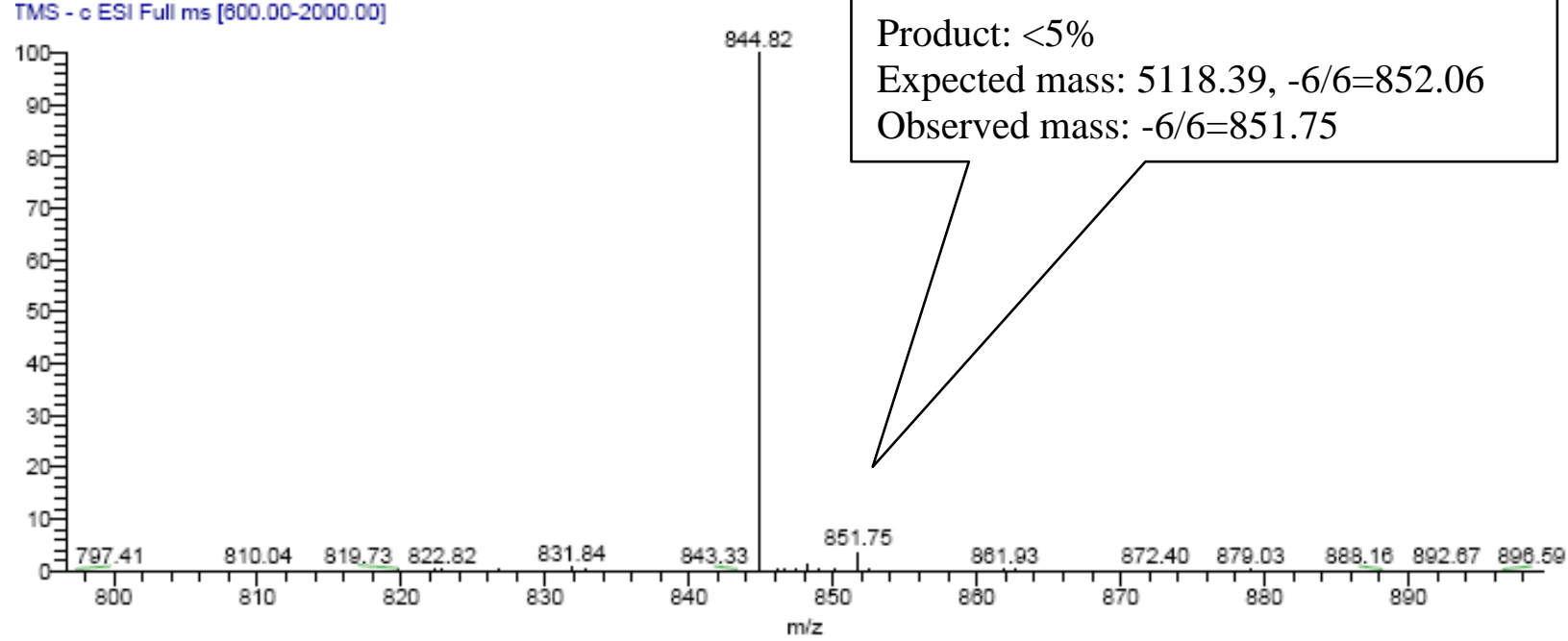


Table 4, entry 1B:

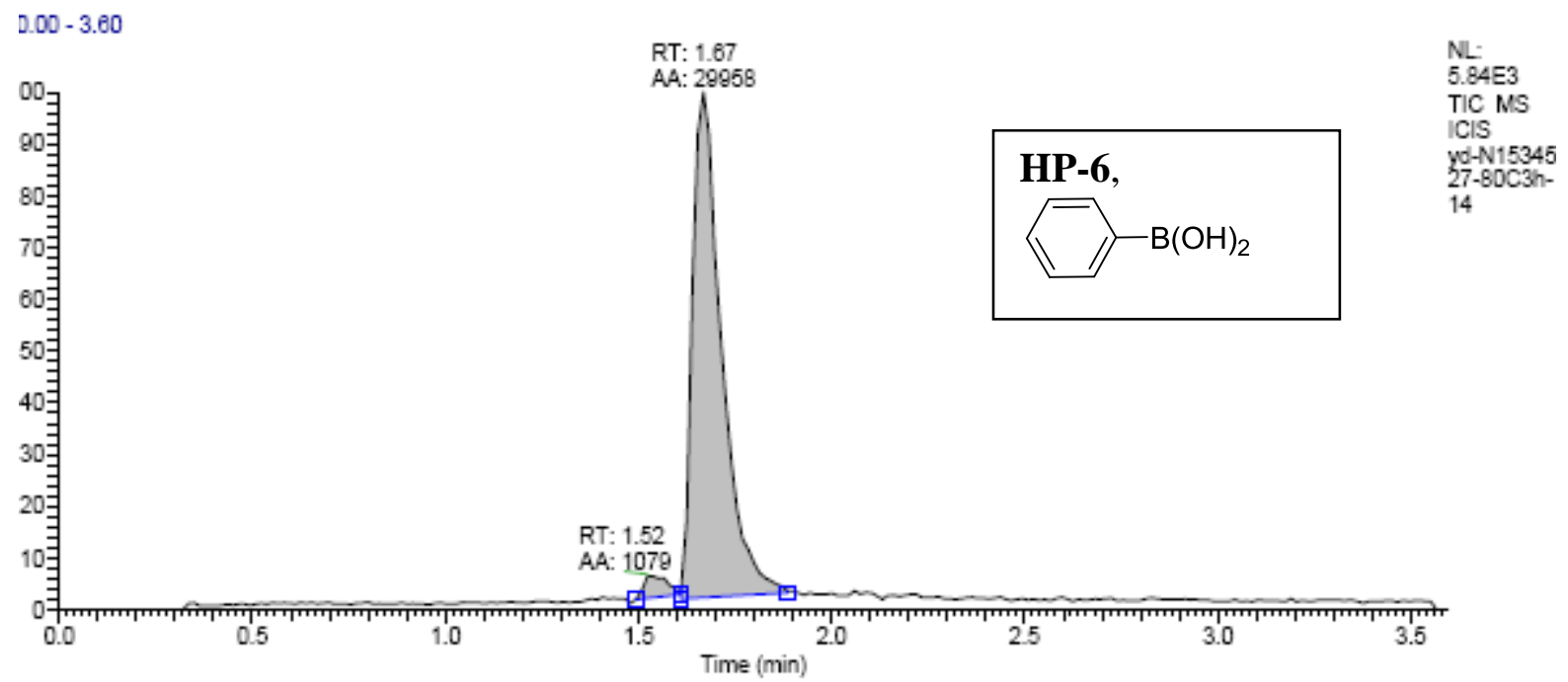

15345-27-80C3h-14 \#104-111 RT: $149-1.60$ AV: 8 NL: 7.56E1

MS - c ESI Full ms [000.00-2000.00]

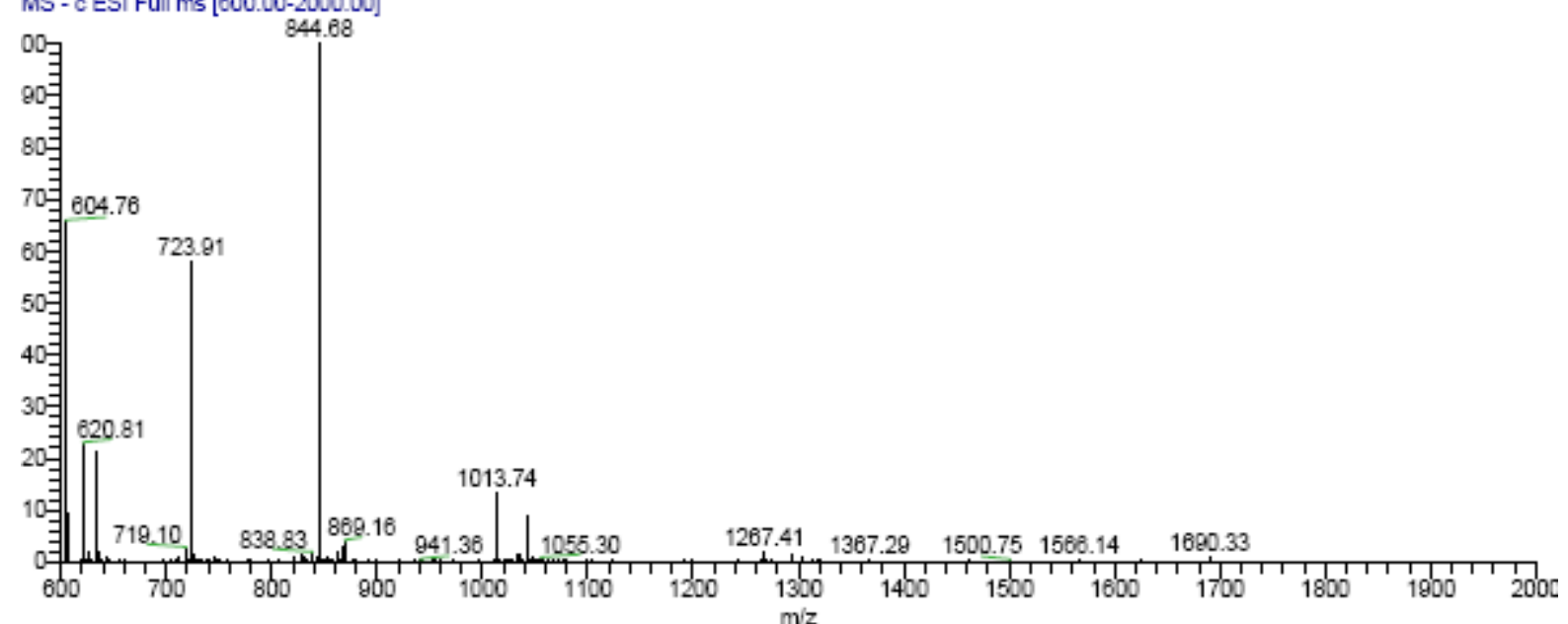

15345-27-80C3h-14 \#112-132 RT: $1.81-1.90$ AV: 21 NL: 6.86E2 MS - c ESI Full ms [000.00-2000.00]

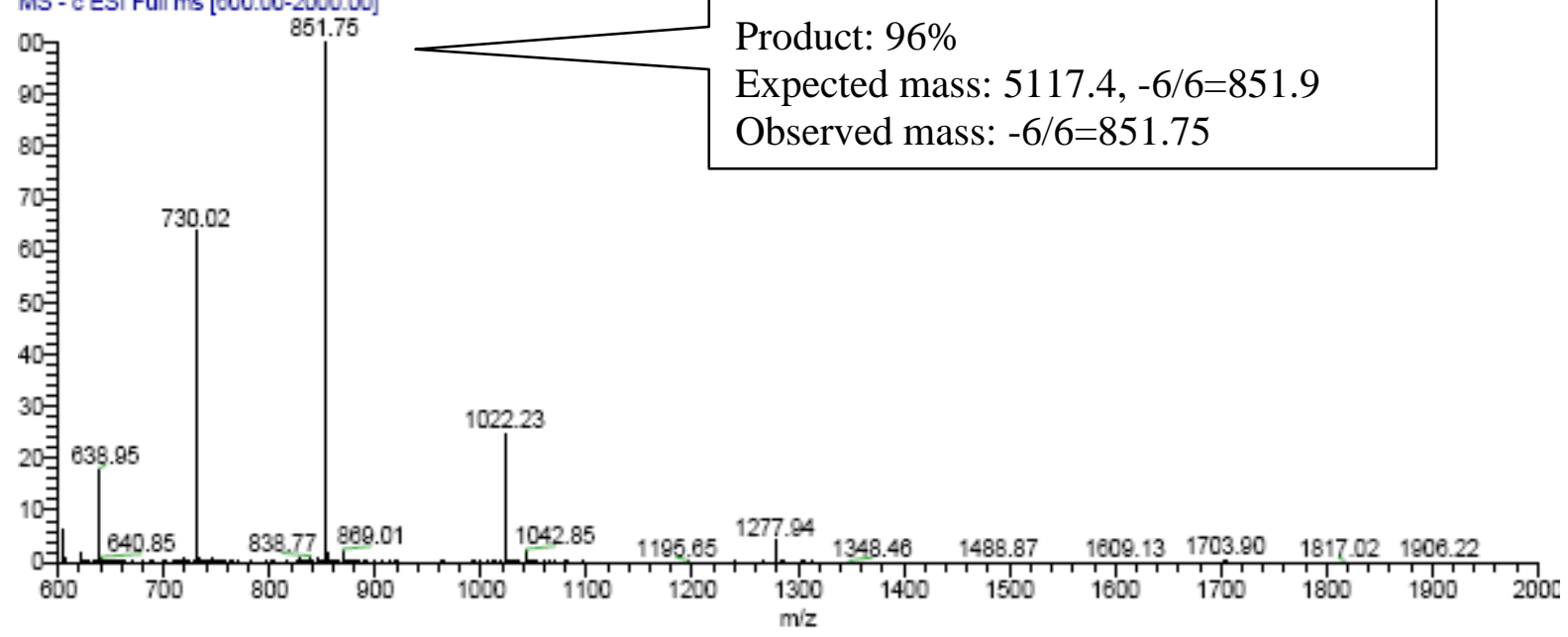


Table 4, entry 2B:

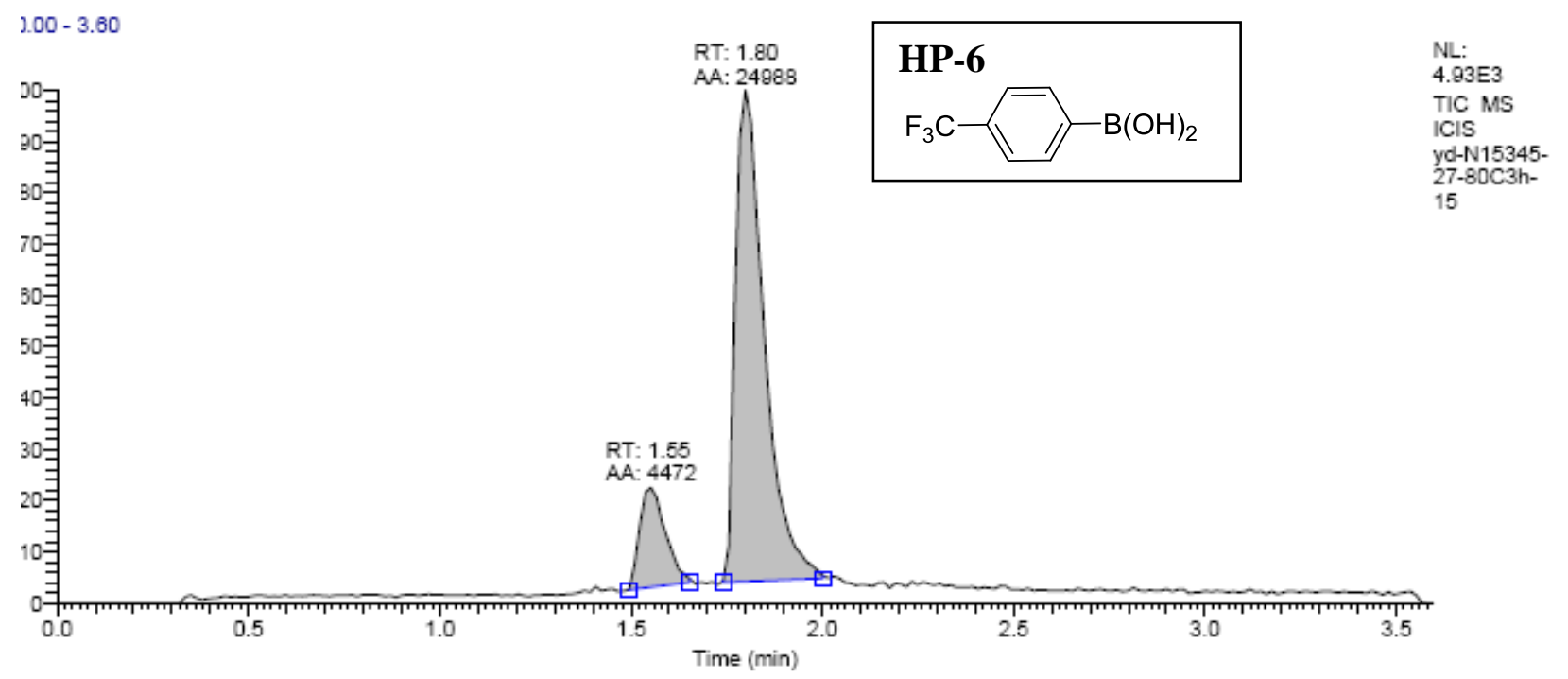

15345-27-80C3h-15 \#104-117 RT: 1.49-1.68 AV: 14 NL: $1.80 E 2$ MS - c ESI Full ms [800.00-2000.00]

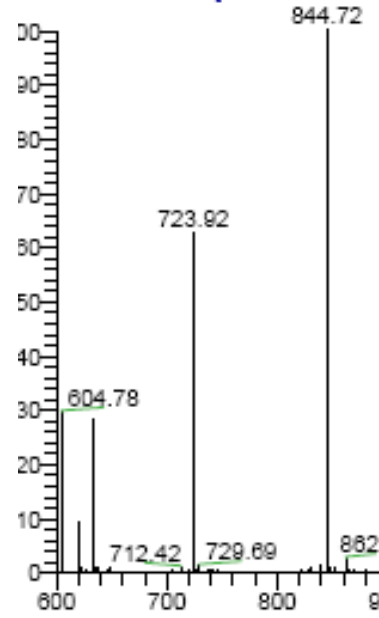

SM: $15 \%$

Expected mass: $5075.75,-6 / 6=844.96$

Observed mass: $-6 / 6=844.72$

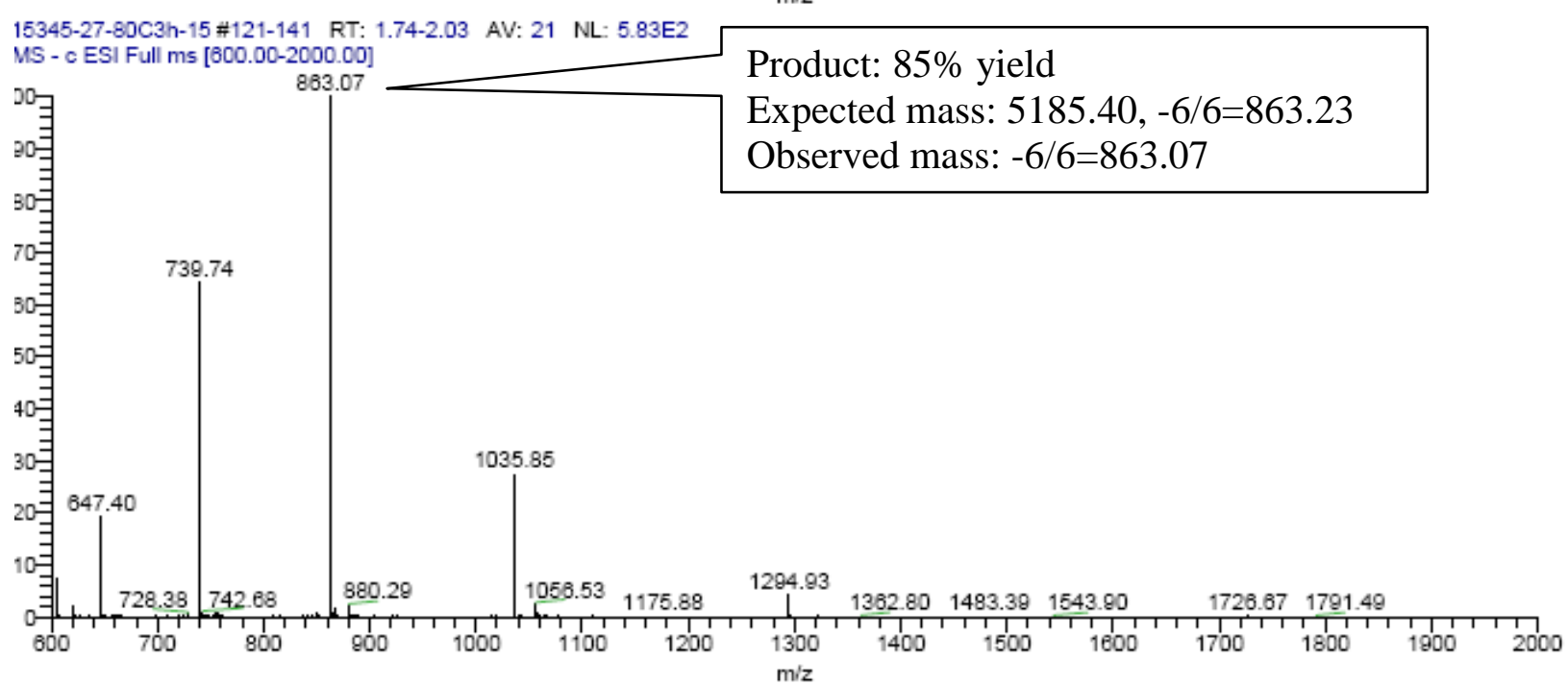


Table 4, entry 3B:
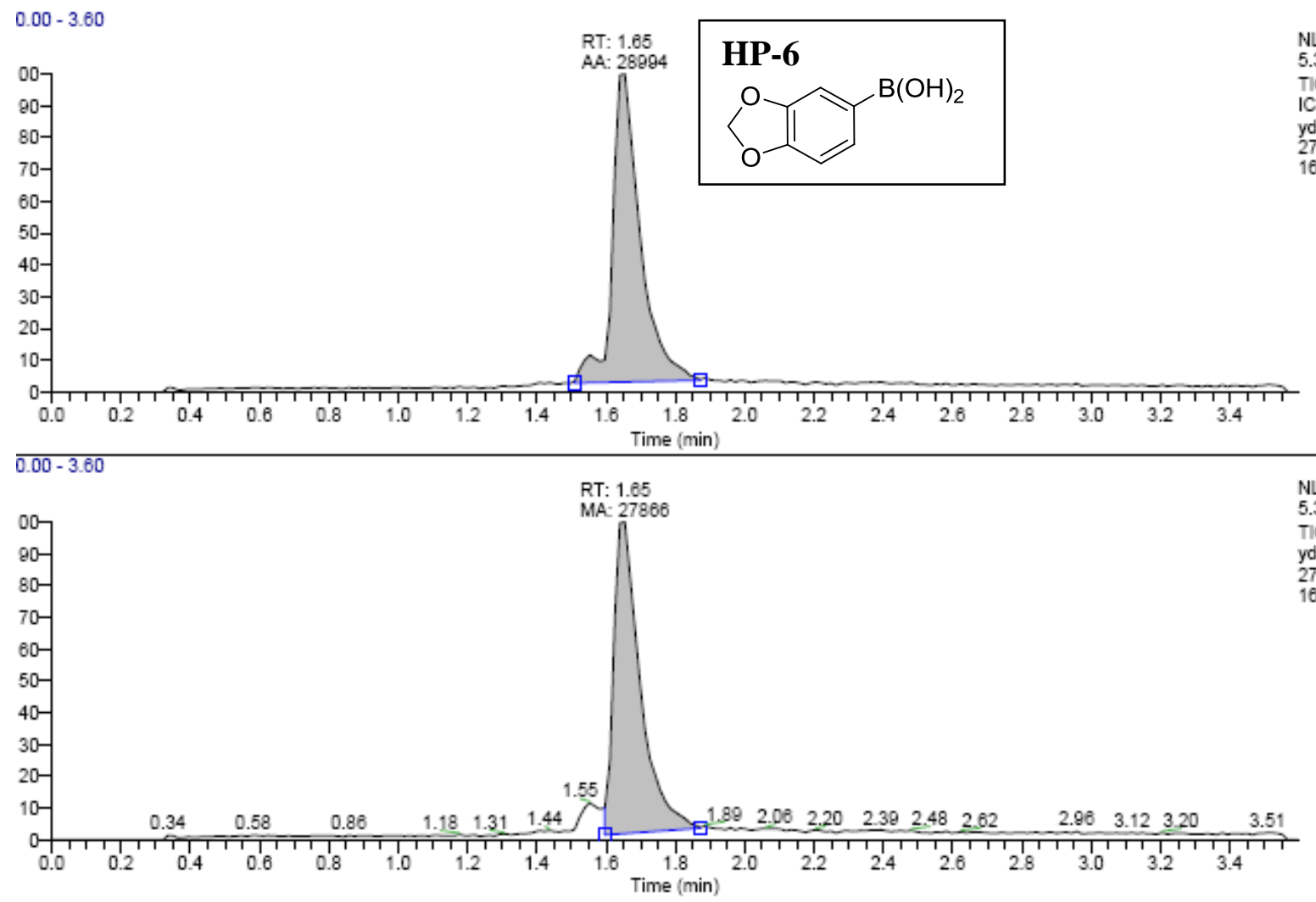

15345-27-80C3h-16 $=105-110$ RT: $1.51-1.58$ AV: 6 NL: $9.74 E 1$

'MS - c ESI Full ms [000.00-2000.00]

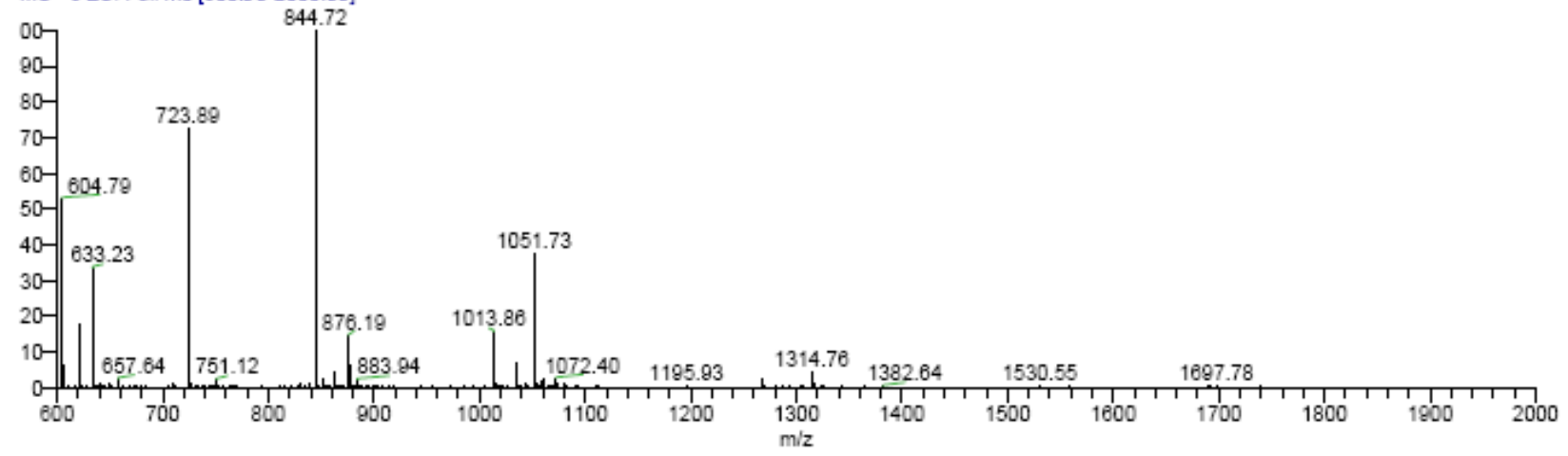

$15345-27-80 C 3 \mathrm{~h}-16=111-130$ RT: $1.60-1.87$ AV: 20 NL: $6.22 E 2$ MS - c ESI Full ms [600.00-2000.00]

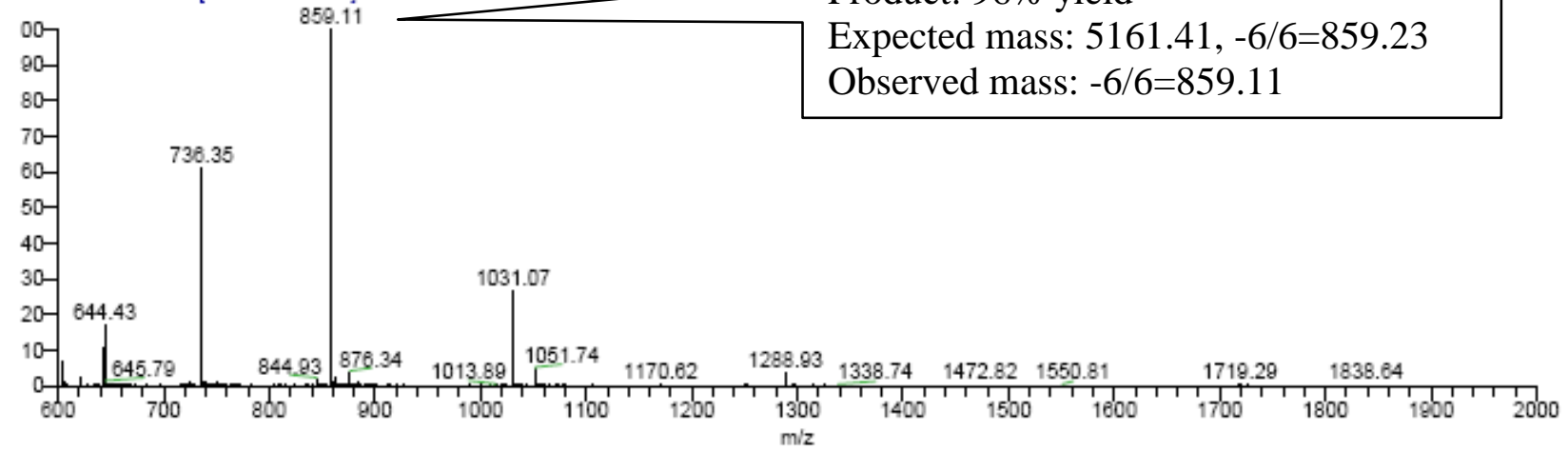


Table 4, entry 4B:
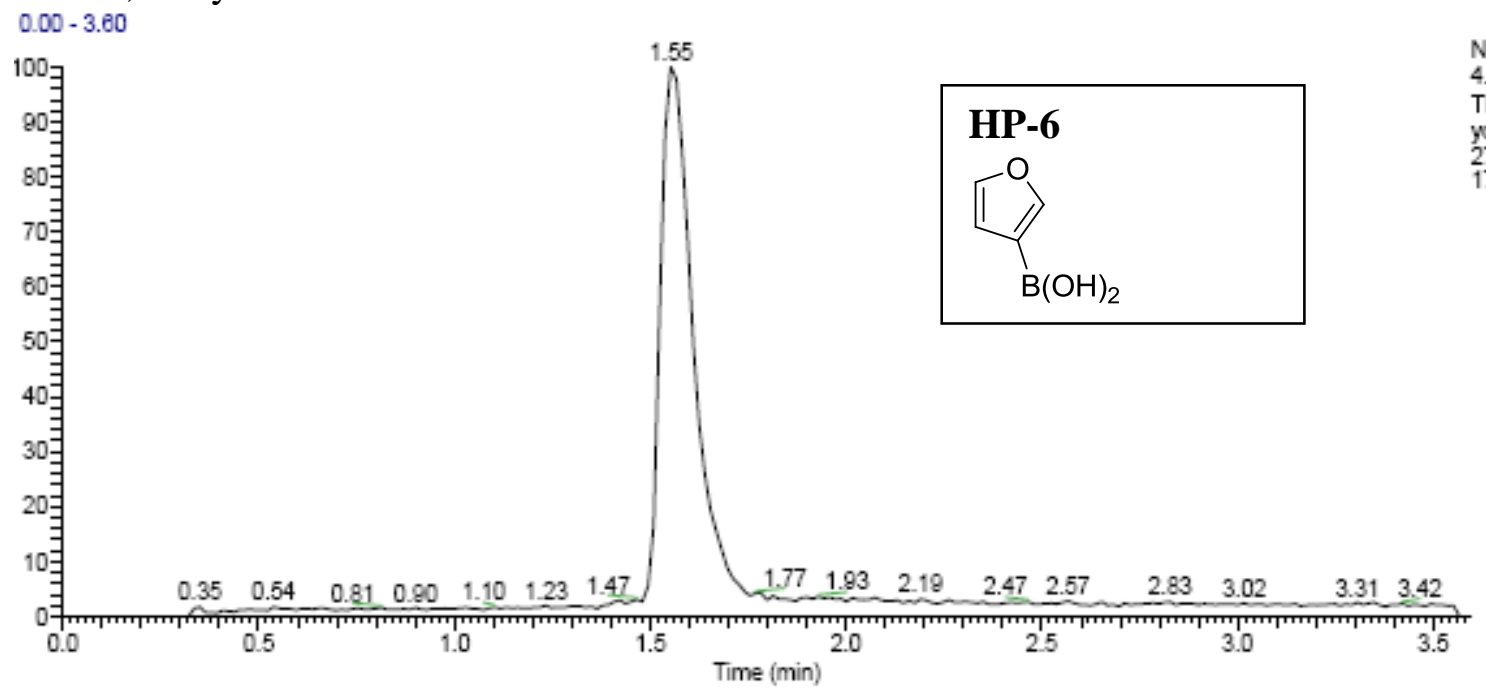

$\mathrm{NL}-$ 4.87E3

115345-27-80C3h-17 \#98-125 RT: $1.41-1.80$ AV: 28 NL: $3.36 E 2$ IMS - c ESI Full ms [000.00-2000.00]

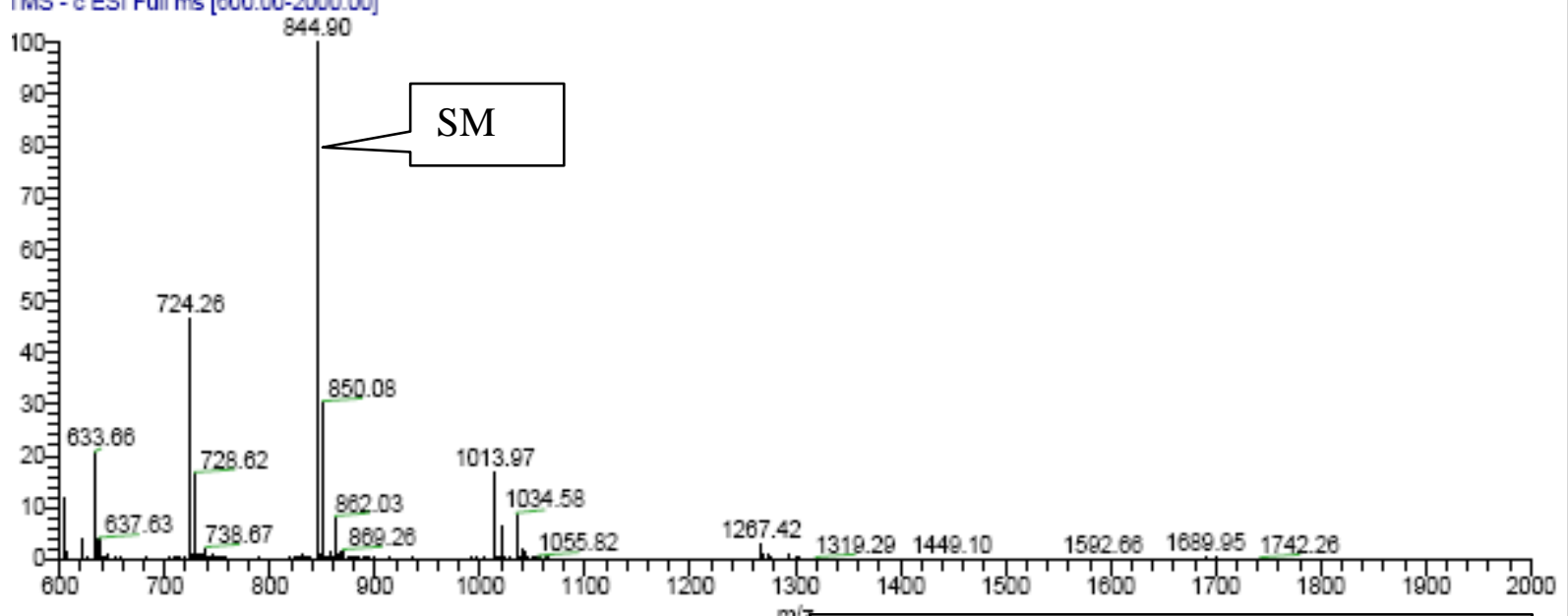
115345-27-80C3h-17 \#98-125 RT: $1.41-1.80$ AV: 28 NL: 3.36E2 TMS - c ESI Full ms [000.00-2000.00]

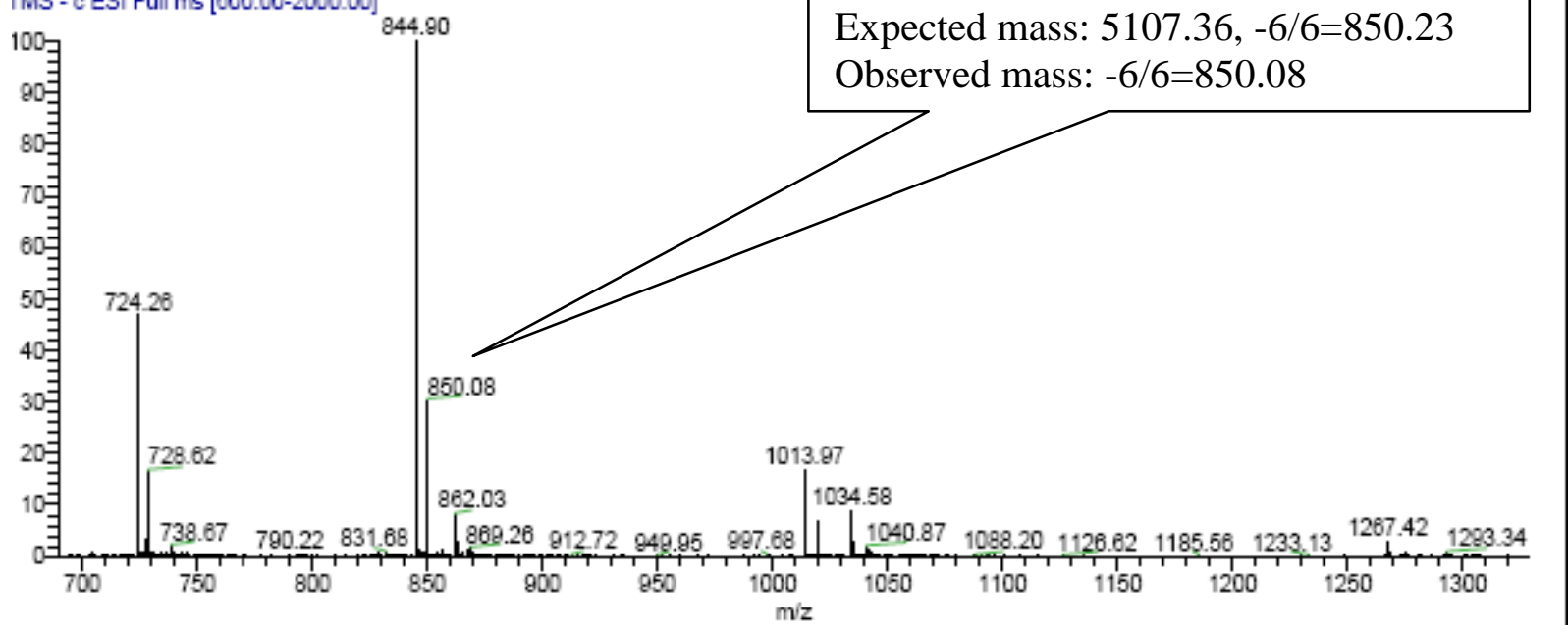


Table 4, entry 5B:
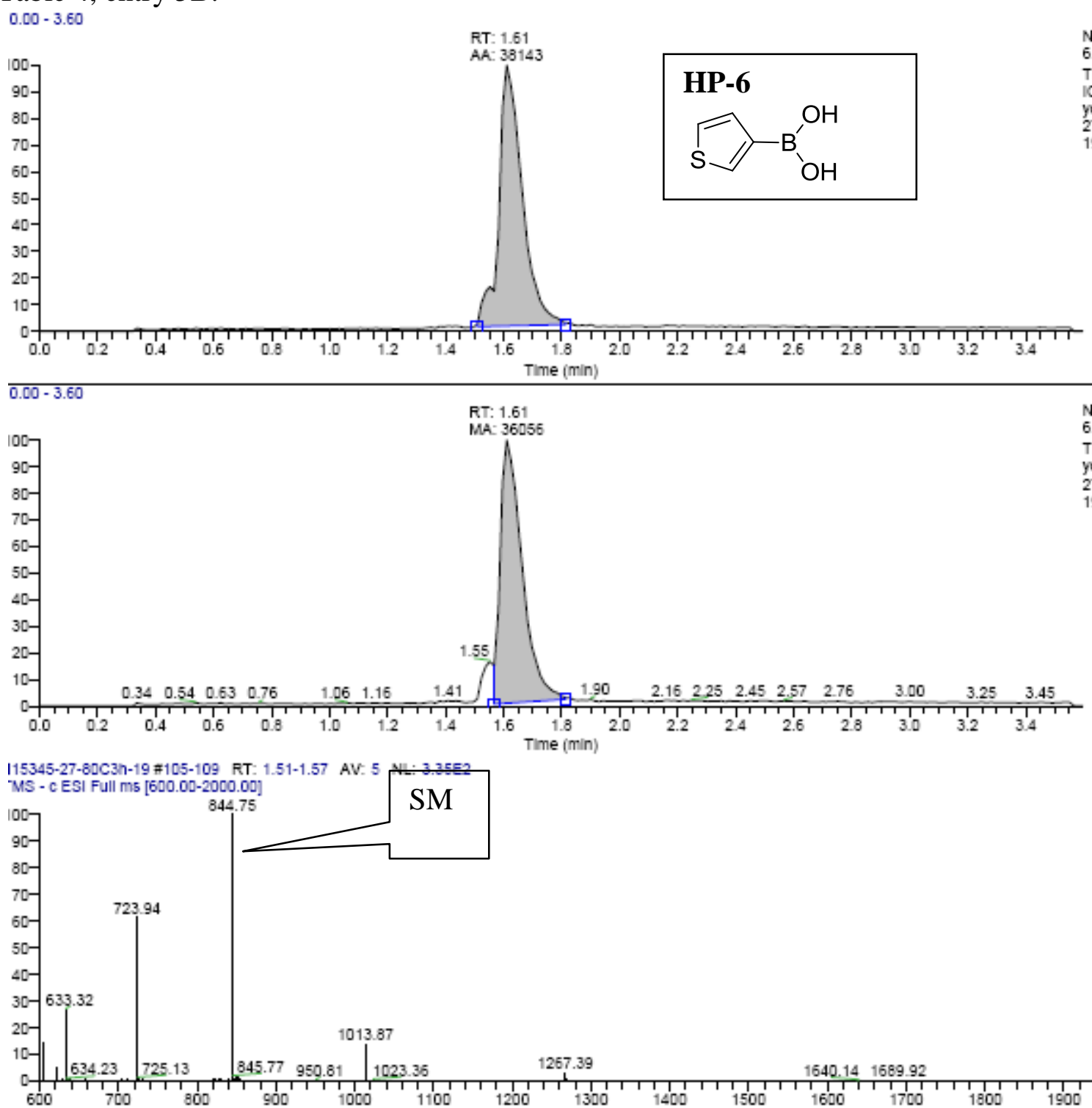

|15345-27-80C3n-19 \#109-128 RT: $1.57-1.84$ AV: 20 NL: $8.40 E 2$ MS - c ESI Full ms [600.00-2000.00]
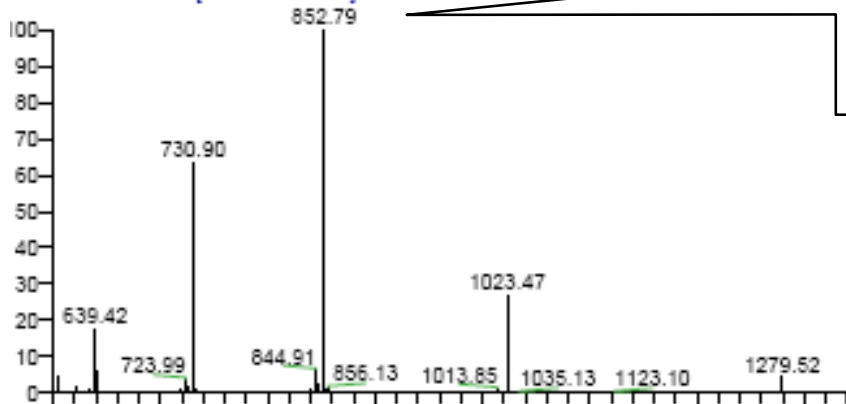

Product: $95 \%$ yield

Expected mass: $5123.43,-6 / 6=852.91$

Observed mass: $-6 / 6=852.79$

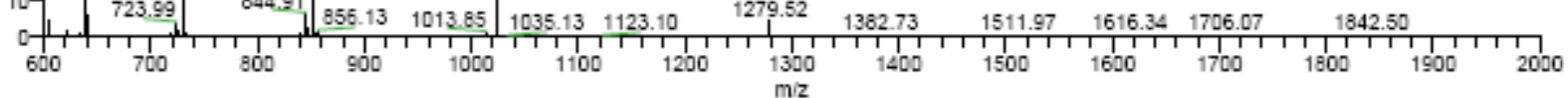


Table 4, entry 6B:
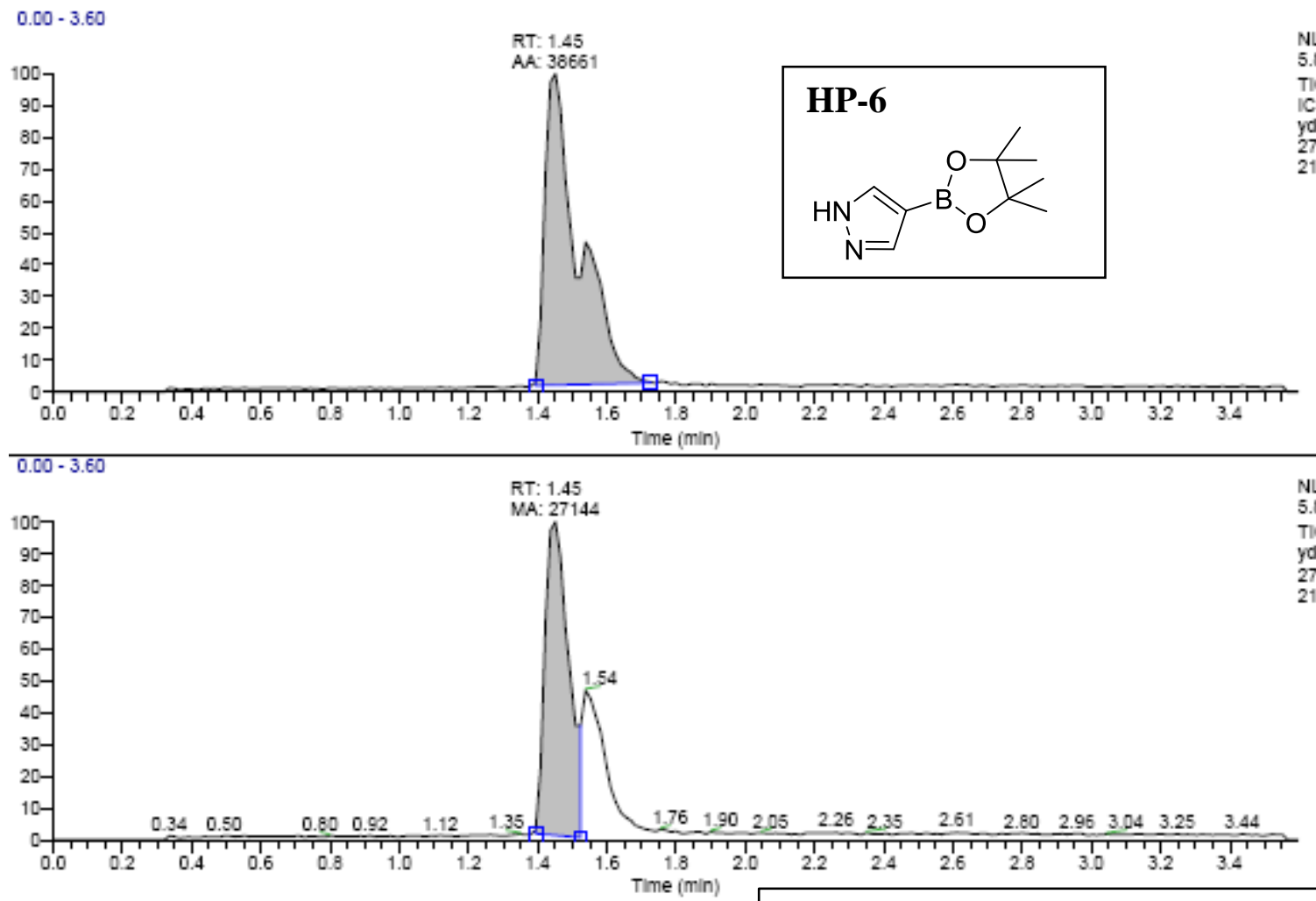

N15345-27-80C3n-21 \#90-104 RT: 1.42-1.49 AV: 6 NL: 1.56E3 Time (min)
TMS - C ESI FUll M5 [600.00-2000.00]

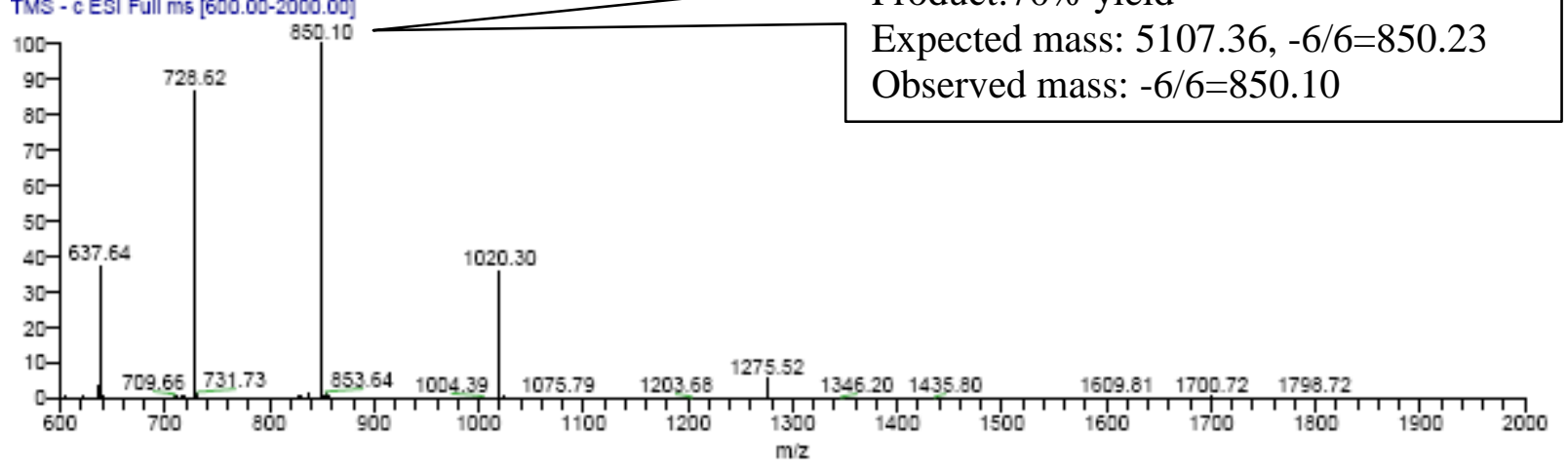

V15345-27-80C3n-21 \#107-116 RT: $1.54-1.67$ AV: 10 NL: 4.76E2

TMS - c ESI Full mo [600.00-2000.0D]

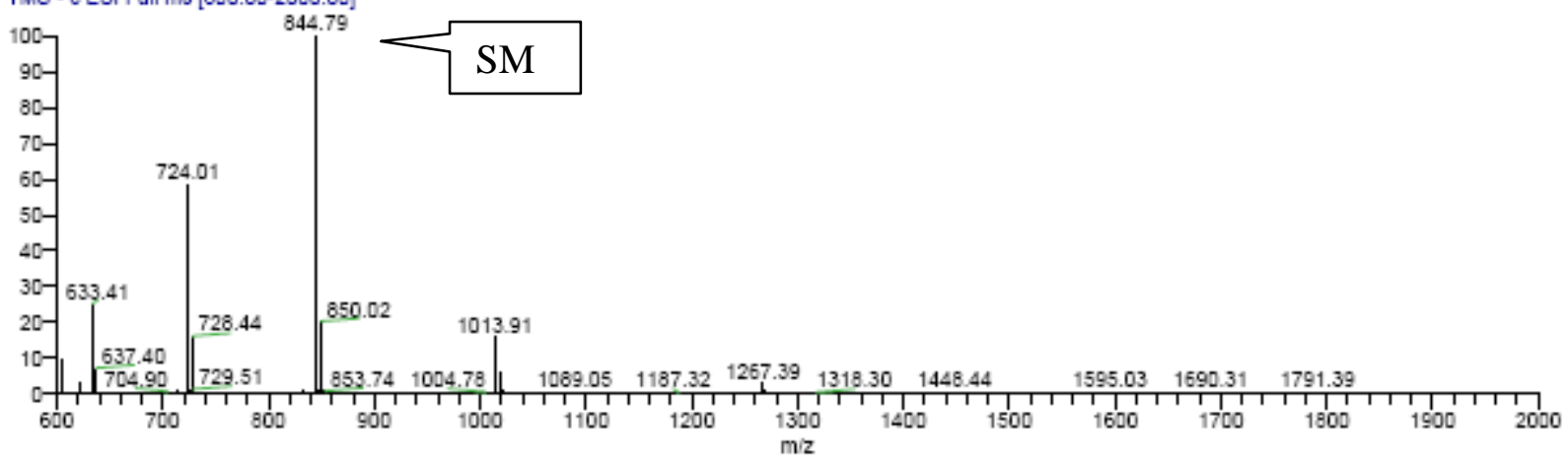


Table 4, entry 7B:

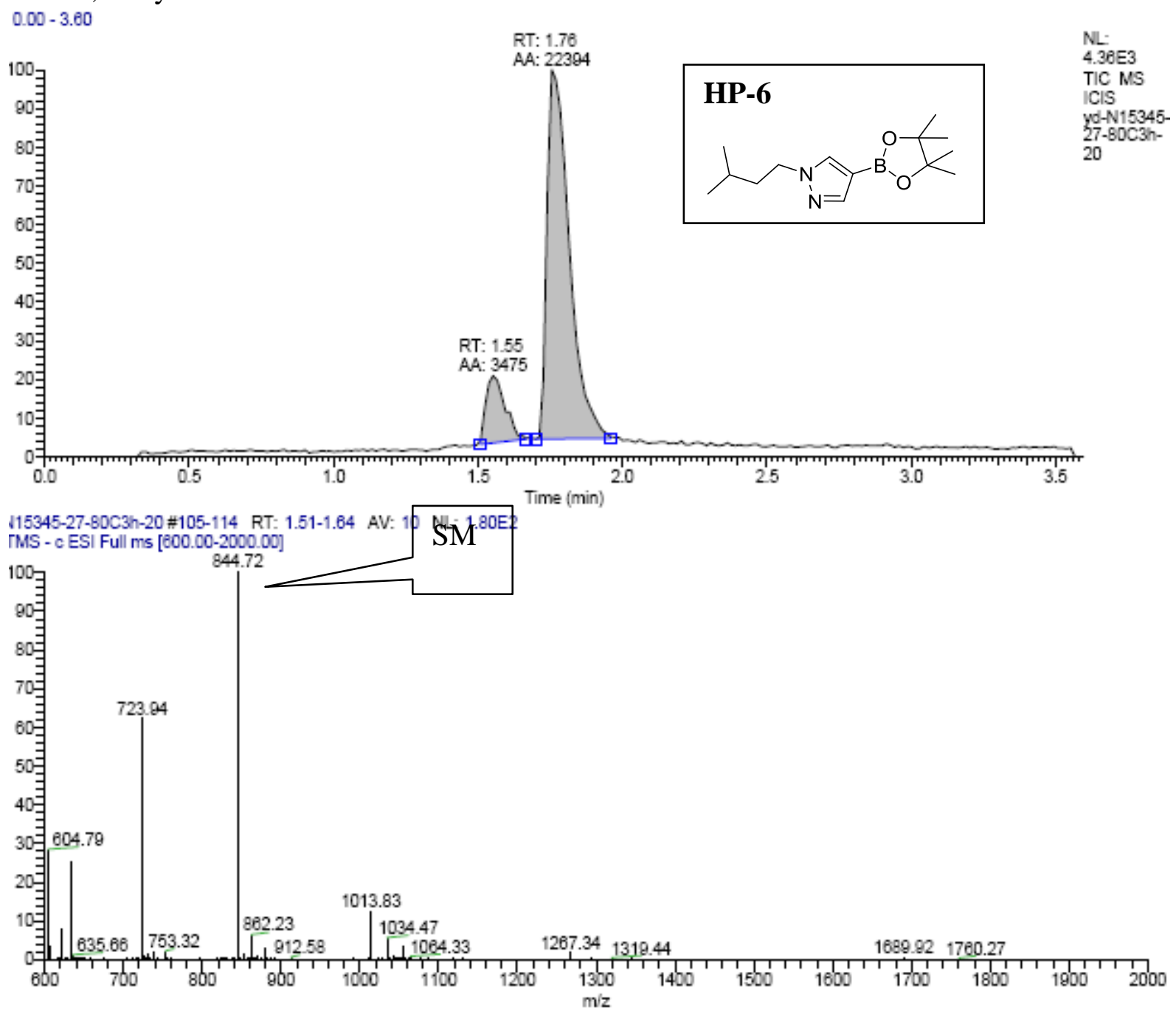

115345-27-80C3h-20 \#119-138 RT: 1.71-1.99 AV: 20 NL- 4.87E2

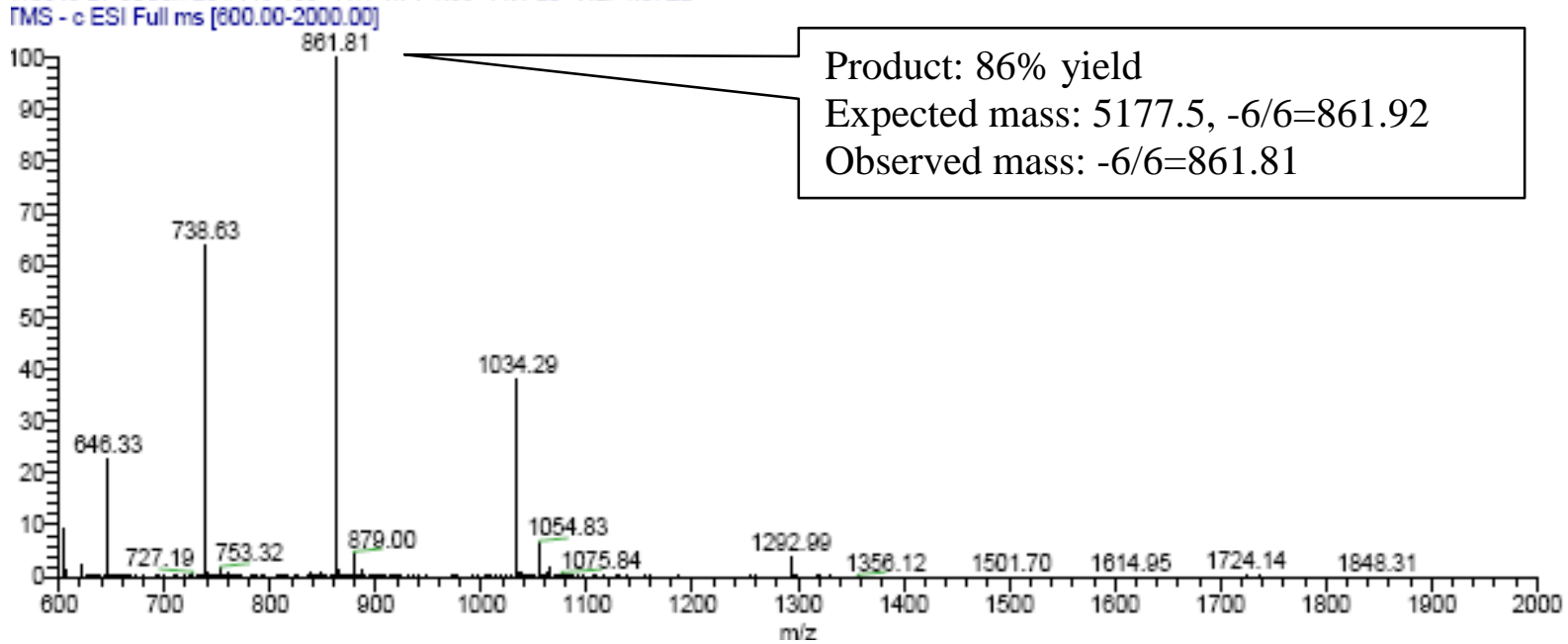


Table 4, entry 8B:

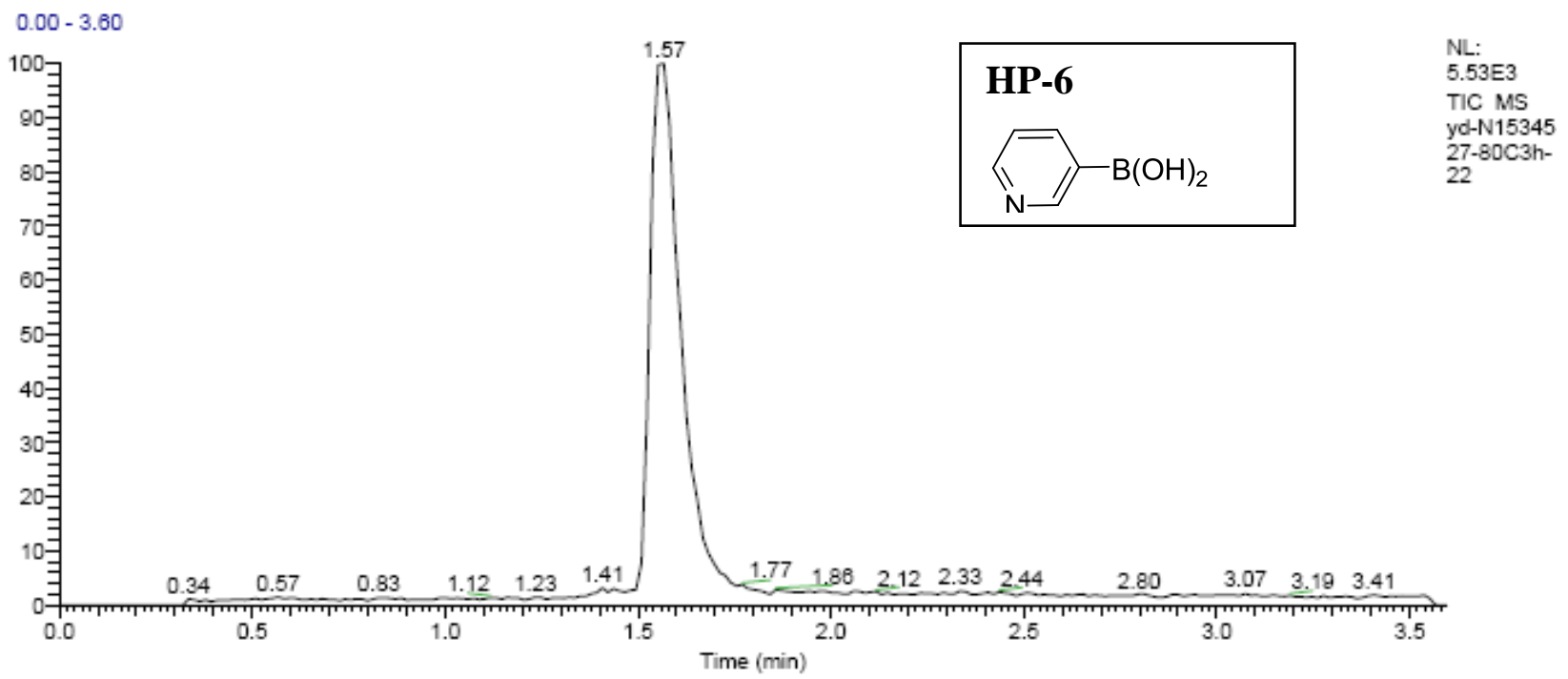

V15345-27-80C3h-22 \#104-124 RT: 1.49-1.78 AV: 21 NL: $4.12 E 2$ TMS - c ESI Full ms [800.00-2000.00]

851.90

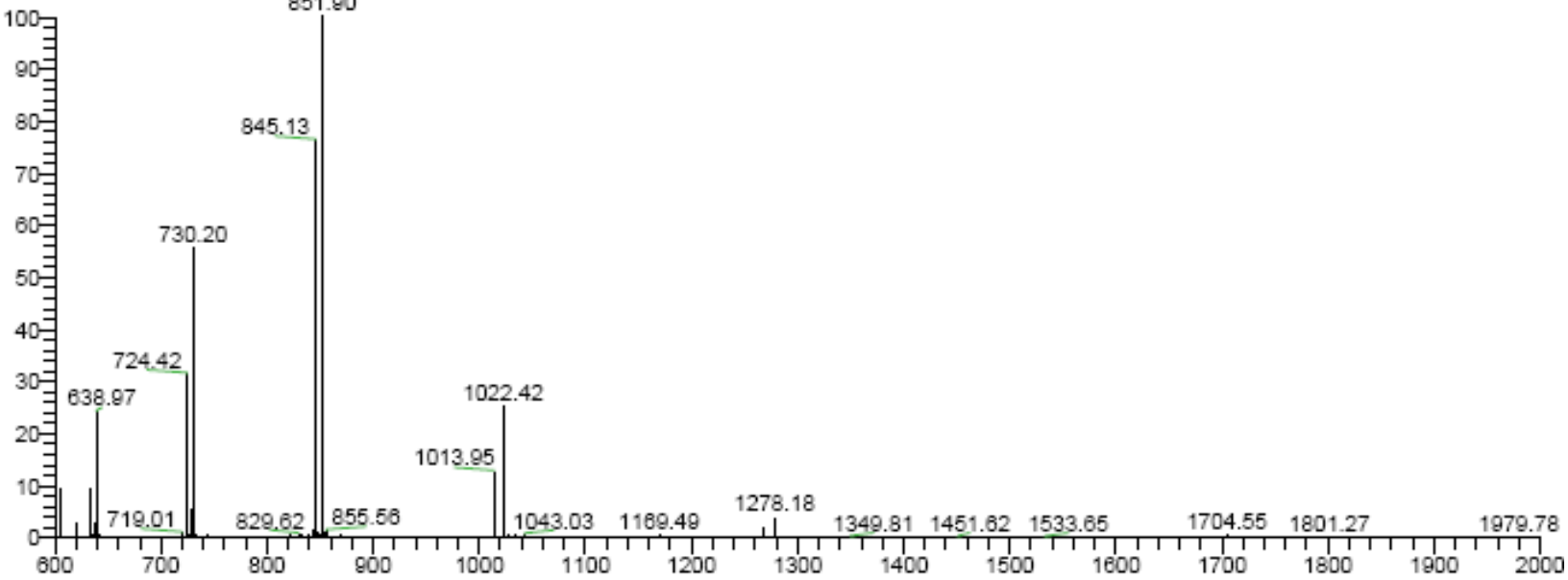

V15345-27-80C3h-22 \#104-124 RT: 1.49-1.78 AV: 21 NL: $4.12 \mathrm{E} 2$ TMS - c ESI Full ms [600.00-2000.00]

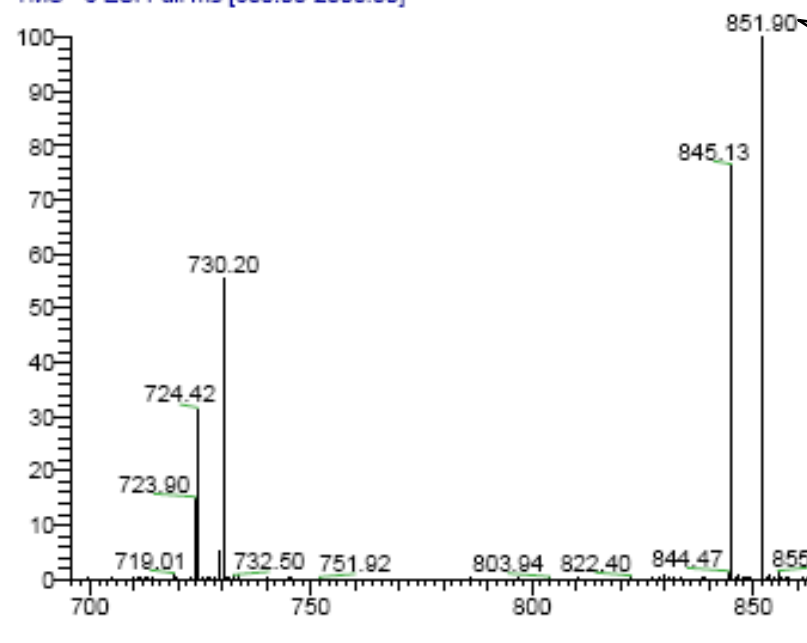

Product: $\sim 60 \%$

Expected mass: $5118.39,-6 / 6=852.06$

Observed mass: $-6 / 6=851.90$ 